\title{
The Architecture of Smart Intelligence: Structuring and Overseeing Agencies in the Post-9/11 World
}

\author{
Anne Joseph O’Connell $\dagger$
}

\section{INTRODUCTION}

The September 11, 2001 terrorist attacks left U.S. policymakers stunned at the country's vulnerability. The attacks resulted, at least in part, from a massive breakdown in the intelligence system designed to identify threats to the nation's security and to provide policymakers with sufficient information to protect against them. ${ }^{1}$ Congress created the National

Copyright (C) 2006 Califomia Law Review, Inc. Califomia Law Review, Inc. (CLR) is a California nonprofit corporation. CLR and the authors are solely responsible for the content of their publications.

$+\quad$ Assistant Professor of Law, Boalt Hall, School of Law, University of California, Berkeley. 1 am grateful to Jamie O'Connell, Eugene Bardach, Melvin Eisenberg, Christopher Elmendorf, Daniel Farber, Philip Frickey, Andrew Guzman, Daniel Ho, Sonya Lebsack, Jonathan Masur, Robert Merges, Paul Schwartz, Martin Shapiro, Matthew Stephenson, Eric Talley, John Yoo, David Zaring, Amy Zegart, editors of California Law Review, and participants in the University of California, Davis, Law School Faculty Workshop, the Boalt Hall-Montpellier University Faculty Conference, Boalt Hall's Advanced Constitutional Theory Student Seminar, the University of California, Los Angeles, Law School Faculty Workshop, the University of California, Berkeley, Leaming in Retirement Program on Constitutional Law, and the American Law and Economics Association's 2006 Annual Meeting for helpful discussions and suggestions. In May 2005, 1 worked with five undergraduates-Paul Angelo (Naval Academy), Albert Chang (Stanford University), Chris Culver (Air Forcc Academy), Becky Perry (University of Texas, Austin), and Marissa Vahlsing (Swarthmore College)-on a policy proposal to reform congressional oversight of the intelligence community; conversations with those students improved my ideas on this topic. Casey Roberts, Bruno Salama, and James Chavez provided extremely helpful research assistance, and Doug Avila of the Boalt Hall Library tracked down copies of many sources. The Boalt Hall Fund provided financial assistance. From 2001 to 2003, I was a trial attorney at the Federal Programs Branch of the U.S. Department of Justice. As a team member helping to review designations of entities linked to terrorism before their assets were frozen and defend those designations when legal challenges were brought, I interacted with members of the intelligence community. Nothing in this Article is based on confidential or classified information, and none of my views should be attributed to the Department of Justice.

1. William E. Odom, Fixing Intelligence for a More Secure America 187 (2003). Judge Posner has questioned this inference. Richard A. Posner, The 9/ll Report: A Dissent, (Review of Final Report of the National Commission on Terrorist Attacks upon the United States), N.Y. TIMES BooK Rev., Aug. 29, 2004, at 1; see also Richard A. Posner, Preventing Surprise ATtACKS: INTElligenCE Reform IN THE WAKE OF 9/11, at 20 (2005); Luis Garicano \& Richard A. 
Commission on Terrorist Attacks upon the United States, commonly known as the $9 / 11$ Commission, to investigate the attacks and to relay "its findings, conclusions, and recommendations for corrective measures that can be taken to prevent acts of terrorism."2 Through months of intense work that included nineteen days of high-profile hearings, more than 1,200 interviews, and review of more than 2.5 million pages of documents, the Commission dissected the attacks and their antecedents. The Commission concluded that they "revealed four kinds of failure: in imagination, policy, capabilities, and management."

To address these failures, the Commission called for extensive reorganization of both the Executive and Legislative Branches of government. ${ }^{4}$ Within the Executive Branch, the Commission recommended that the government's counterterrorism intelligence gathering and operation-planning efforts be unified under a National Counterterrorism Center. The Commission also proposed that the entire intelligence community, which confronts a wider set of national security issues, be unified under a National Intelligence Director who would "oversee national intelligence centers on specific subjects of interest across the U.S. government" and "manage the national intelligence program and oversee the agencies that contribute to it." Within the Legislative Branch, the Commission urged that congressional oversight of the intelligence bureaucracy be consolidated under either a joint intelligence committee of the House of Representatives and the Senate or a single committee in each chamber of Congress. ${ }^{6}$ These recommendations for "significant changes in the organization of the government" contemplate a shift from decentralized, redundant agencies and decentralized, redundant oversight toward centralized, nonredundant agencies and centralized, nonredundant oversight.

The 9/11 Commission's final report garnered tremendous attention when it was published in $2004,{ }^{8}$ and the Commission's members, until recently operating as the 9/11 Public Discourse Project, remain important

Posner, Intelligence Failures: An Organizational Economics Perspective, 19 J. EcoN. PERsP. 151, 152 (2005).

2. Intelligence Authorization Act for Fiscal Year 2003, Pub. L. No. 107-306, § 602, II6 Stat. 2383, 2408 (2002).

3. National Commission on Terrorist attacks upon the United States, The 9/i I COMMISSION REPORT Xv, 339 (2004) [hereinafter $9 / 1$ I COMMISSION REPORT].

4. Id. at 399 .

5. Id. at 403,407 .

6. Id. at 420 .

7. Id. at 399

8. The report was distributed free on the 1nternet. See http://www.9-11commission.gov. The authorized hard copy remained at the top of the New York Times nonfiction best-seller list for eleven weeks and earned a nomination for the National Book Award for nonfiction. Thomas Crampton, If $9 / 11$ Report Wins Award, Will 90 Authors Rise?, N.Y. TimEs, Oct. 24, 2004, at A21. 
voices in reform debates. ${ }^{9}$ The bipartisan Commission on the Intelligence Capabilities of the United States Regarding Weapons of Mass Destruction, popularly known as the WMD Commission, made complementary calls for organizational change in its well-publicized report last year. ${ }^{10}$ These two reports have become key forces behind reorganization of the administrative state, including the Intelligence Reform and Terrorism Prevention Act of 2004 (Intelligence Reform Act), signed by President Bush in December 2004. " The Act created a Director of National Intelligence (DNI) to lead the intelligence community and to serve as the President's primary intelligence advisor for national security, functions previously performed by the Director of the Central Intelligence Agency (CIA). ${ }^{12}$

This Article questions that siren call of unification on the grounds of national security effectiveness, political feasibility, and democratic legitimacy. Unification may encourage coordination across agencies and committees and reduce resources devoted to maintaining duplicative structures, among other benefits. Unification can, however, have costs as well: for example, destroying needed safeguards and eliminating beneficial agency or committee competition. Finding a desirable and politically feasible balance between unification and redundancy is a difficult task, and a pressing one.

The changes to bureaucratic structure and oversight recommended by the 9/1I and WMD Commissions-- both those changes implemented and those not adopted - raise fundamental questions of administrative and constitutional law. These questions cut to the heart of the federal government's effectiveness in addressing two of the most prominent policy imperatives of our time: protecting national security and maintaining core democratic values, which include civil liberties, transparency, and accountability. First, how should agencies be structured in a system of separate but overlapping powers, a system that aims to protect both national security and central liberal democratic values? Should administrative agencies be combined or placed in competition with each other? Second, what authority should be delegated to these agencies, which do not fall neatly into any constitutional

9. See, e.g., Philip Shenon et al., 9/II Panel Members Ask Congress to Learn if Pentagon Withheld Files on Hijackers in 2000, N.Y. TiMEs, Aug. 10, 2005, at A14.

10. Commission on the INTElligence Capabilities of the United States Regarding Weapons of Mass Destruction, Final Report (2005) [hereinafter WMD Report]. Federal Judge Laurence H. Silberman and former Senator Charles S. Robb (D-VA) headed the nine-member bipartisan Commission, which concluded that the intelligence community's prewar conclusions about lraq's weapons of mass destruction were "one of the most public - and most damaging-intelligence failures in recent American history." Id. at 3; see also Letter from the Commission on the Intelligence Capabilities of the United States Regarding Weapons of Mass Destruction to President George W. Bush (Mar. 31, 2005), available at www.wmd.gov/report/transmittal_letter.pdf.

11. Intelligence Reform and Terrorism Prevention Act of 2004, Pub. L. No. 108-408, 118 Stat. 3638 (2004) [hereinafter IRA].

12. WMD REPORT, supra note 10 , at 585 . 
category? Should responsibilities related to national security be easier or harder for Congress to delegate to administrative agencies than powers related to other policy areas? Does agency structure, such as independence from the President, matter for national security or civil liberties? Third, how should Congress and other institutions oversee the delegations of power? How should our system of checks and balances operate for intelligence activities? Political realities constrain answers to these legal and normative questions. As political scientist Terry Moe explains, "The bureaucracy arises out of politics, and its design reflects the interests, strategies, and compromises of those who exercise political power."13

This Article offers a comprehensive analytical approach for evaluating these questions. The approach combines crucial sets of concerns for agency structure and oversight, including effectiveness for national security, political and legal feasibility, and respect for fundamental constitutional and democratic values. The 9/11 and WMD Commission Reports typically portray redundancies within both the intelligence community and Congress as liabilities, because they increase costs and decrease information sharing. By contrast, Judge Posner, who has written extensively on questions of national security, generally perceives redundancies within the intelligence community as assets, because they appear to create a competitive market for intelligence, and redundancies within Congress as liabilities, because they often interfere with intelligence work. Each approach misses critical insights on its own terms, and fails to include necessary components for agency design in a democratic system. This Article fills in some of these lacunae and offers a framework that applies beyond the intelligence community and its congressional overseers to other policy areas.

Part I summarizes the most important recent proposals for restructuring the intelligence community and congressional oversight; it also describes both attempted and successful efforts to enact those recommendations. Part II, drawing on insights from economics and political science concerning public and private organizations, considers three important perspectives on the $9 / 11$ Commission's recommendations to unify intelligence agencies and congressional oversight: effectiveness in enhancing national security, political and legal feasibility, and democratic legitimacy. The three have not, so far as I can tell, been applied to intelligence reform rigorously in combination. These perspectives, which combine description, causal analysis, and normative prescriptions, also have wider application to any possible restructuring of the administrative state. ${ }^{14}$

13. Terry M. Moe, The Politics of Bureaucratic Structure, in CAN THE Government Govern? 267, 267 (John E. Chubb \& Paul E. Peterson eds., 1989).

14. Amy Zegart has analyzed parts of the first two perspectives, effectiveness and political feasibility, for the intelligence community. Amy B. Zegart, September 11 and the Adaptation Failure of U.S. Intelligence Agencies, 29 INT'L SECURITY 78 (2005). For a thorough theoretical consideration of the first and second perspectives for any agency mergcr, see Karen M. HULT, AGENCY MERGER AND 
More specifically, Section II.A seeks the most effective structure of the intelligence bureaucracy and congressional oversight for national security, taking into account both benefits and costs. When does redundancy (or decentralization) in bureaucratic delegation and oversight create optimal outcomes? And, when is unification (or centralization) more effective? Further, this Section notes that the selection of an effective structure of the intelligence community depends on the structure of congressional oversight, and vice-versa. Section II.B considers what structures are politically and legally feasible. It is very difficult, though not impossible, to change jurisdictions of agencies and congressional committees. The Intelligence Reform Act changed some agency jurisdictions, but it did not shift congressional boundaries. What jurisdiction did agencies lose under the Act and why was that loss permitted? What will encourage members of Congress to give up committee "turf'? What structures does our constitutional system of separate but overlapping powers allow? Section II.C examines the types of agency and congressional structures that a democratic society should desire. How does the organization of the intelligence community and congressional oversight affect core liberal democratic values such as civil liberties, transparency, and accountability?

Part III examines how policymakers might combine these three perspectives to make decisions about the structure of the intelligence community and its congressional overseers, as well as other areas of the administrative state. Part IV applies insights from Parts II and III to make some recommendations concerning the organization of the intelligence community and the community's congressional monitors. Part V concludes. The Appendix presents a simple game theory model to help illustrate several concepts discussed in Part II.

I

\section{Major Reform Proposals and Their Present Status}

The 9/1 I Commission was not the first group to call for reform of the intelligence community; such calls have persisted for decades. ${ }^{15}$ In the six

\footnotetext{
Bureaucratic Redesign (1987). For applications to agency design for tax and spcnding, see David A. Weisbach \& Jacob Nussim, The Integration of Tax and Spending Programs, 113 YALE L.J. 955 (2004) (first perspective), and Nancy Staudt, Redundant Tax and Spending Programs, 100 Nw. U. L. Rev. 1197 (2006) (first and second perspectives, of which my project was developed independently). For a discussion of the first and second perspectives for agency design for food safety, see Richard A. Merrill \& Jeffrey K. Francer, Organizing Federal Food Safety Regulation, 31 SETON HALL L. REv. 61 (2000). Because "[f]our federal agencies share primary responsibility for federal food safety," id. at 90 , that case study offers insights into agency design of the intelligence community.

15. In the mid-1940s, the intelligence community underwent its first major restructuringincluding the creation of the CIA - which "emphasized centralization in order to avert futurc Pearl Harbors caused by fragmentation of authority..." Richard K. Betts, Analysis, War, and Decision: Why Intelligence Failures are Inevitable, 30 WORLD PoLITICs 61, 77 (1978) [hereinaftcr Analysis, War, and Decision]. The high-profile investigations of the ClA and FBI by the Rockefeller
} 
years before September 11, 2001, at least ten public and private groups issued major reports that pushed for structural reform of the intelligence community. ${ }^{16}$ Many of these proposals confronted significant opposition from the intelligence community, the incumbent presidential administration, and members of Congress; few were enacted. ${ }^{17}$ Nor was the 9/11 Commission the first to call for reform of congressional oversight of the intelligence community. Just a year after the National Security Act of 1947 created the CIA, Representative Edward Devitt (R-MN) called for a joint committee on intelligence. ${ }^{18}$

This Part examines the most recent reform efforts. It begins with background on the intelligence community and its congressional overseers. It then discusses the $9 / \mathrm{I}$ I Commission and its primary recommendations for organizational change of the intelligence community and of congressional oversight. Finally, this Part considers efforts to enact these recommendations, and further calls for change by the WMD Commission, the 9/11 Public Discourse Project, and others.

\section{A. Background on the Intelligence Community and Congressional Oversight}

Before September 11, 2001, the structure of the intelligence community and associated congressional oversight could best be described as one of multiple, decentralized intelligence agencies and multiple, decentralized congressional overseers. Sixteen agencies or components of agencies now make up the intelligence community; all but one existed in some form

Commission, Church Committee, and Pike Committee in the 1970s focused on "covert operations and government abuses of civil liberties, rather than the accuracy of intelligence information and analysis." Richard K. Betts, The New Politics of Intelligence: Will Reforms Work This Time?, ForEIGN AFF., May/June 2004, at 3 [hereinafter New Politics]. These investigations concluded that the intelligence community needed effective congressional oversight, contributing to the creation of the House and Senate Intelligenee Committees. Frederick M. KAISER, A JoInt CommitTeE on INTElligence: Proposals and Options from the $9 /$ I I COMmission and OTHERs, CRS RePORT 32525, at 2 (2004). Other investigations in the 1970s focused on intelligence analysis and, specifically, on the structure of the intelligence community. One 1971 classified report by the Office of Management and Budget (OMB) identified "two disturbing phenomena": the increase in the intelligenee community's costs and the lack of "commensurate improvement in the scope and overall quality of intelligence products." James Schlesinger, Office of Management and Budget, A Review of the Intelligence Community, at 1 (1971). The report determined that the intelligence agencies' "activities are dominated by collection competition and have become unproductively duplicative" and evaluated options for coordination and consolidation. Id. at 8, 25-47.

16. Thomas H. Hammond, Why is the Intelligenee Community so Difficult to Redesign? 2-3 n.1 (May 5, 2004) (unpublished manuscript on file with author) (detailing reports); see also Zegart, supra note 14, at 85-86 (listing "six bipartisan blue-ribbon commissions, three major unclassified governmental initiatives, and three think tank task forces" between the collapse of the Soviet Union and the September 11, 200I attacks).

17. Jeffrey T. Richelson, The U.S. INTElligence Community 453-54 (4th ed., 1999); WMD REPORT, supra note 10 , at 6 ("[C]ommission after commission has identified some of the same fundamental failings we see in the Intelligenee Community, usually to little effect.").

18. KAISER, supra note 15, at 1 (citing H.R. Res. 186, 80th Cong. (introduced Apr. 21, 1948)) 
before the attacks. ${ }^{19}$ The Department of Defense houses eight of these: the Defense Intelligence Agency (DIA), the National Security Agency (NSA), the National Geospatial-Intelligence Agency (NGIA), the National Reconnaissance Office (NRO), and the intelligence units of each service (Army, Navy, Air Force, Marines). ${ }^{20}$ The Departments of Energy, Homeland Security, Justice, State, and Treasury each have at least one unit devoted to intelligence work. ${ }^{21}$ The most prominent intelligence agency is the CIA, which does not sit within a cabinet department. ${ }^{22}$ Its independence potentially allows the agency more flexibility. Prior to 2005, the Director of the CIA served as the nominal head of the intelligence community as the Director of Central Intelligence, but had little influence over the work of any agency other than the CIA..$^{23}$

These agencies are variously mandated to collect, refine, analyze, and/or distribute information potentially relevant to national security. Each agency employs one or more of the following sources of information: human contacts; communications and other transmissions of data, such as intercepted telephone calls and emails; images and other geospatial data from satellites and spy planes; distinctive information indicating that particular events such as nuclear tests have occurred; or open (public) sources such as newspapers and web pages. ${ }^{24}$ Some agencies engage in

19. Office of the Director of National Intelligence, Members of the Intelligence CoMmunity, available at http://www.dni.gov/who_what/members_1C.htm; see also National Security Act of $1947 \S 3(4), 50$ U.S.C. $\$ 401$ a(4) (as amended).

20. WMD REPORT, supra note 10 , at 580 .

21. These units are: Department of Homeland Security, Directorate of Information Analysis and Infrastructure Protection; Department of Homeland Security, U.S. Coast Guard Intelligence; Department of Energy, Office of Intclligence; Department of Justice, Federal Bureau of Investigation; Department of Justice, Drug Enforcement Administration (DEA); Department of State, Bureau of Intelligence and Research; and Department of Treasury, Office of Terrorism and Financial Intelligence. Id. at 580-81 (excluding DEA); Richard A. Best, IR., INTElligence Issues for Congress, CRS REPORT 33539, at 2 (July 12, 2006) (including DEA); OfFICE OF THE Director of NationaL INTELLIGENCE, supra note 19 (including DEA).

22. WMD REPORT, supra note I0, at 580. The history of the intelligence community is fascinating. For example, the DIA was created to provide coordination and reduce duplication among the military services' intelligence units. But the services' intelligence components fought to remain as powerful players. See Richelson, supra note 17, at 55-60, 74-75. For additional background on mcmbers of the intelligence community, sec id.; BEST, supra note $2 \mathrm{I}$, at $2-4$.

23. 9/I I COMMISSION REPORT, supra note 3, at 86; RICHELSON, supra note I7, at 387.

24. WMD REPORT, supra note 10, at 582-83. Formally, the term "intelligence" includes foreign intelligence, which "means information relating to the capabilities, intentions, or activities of foreign governments or elements thereof, forcign organizations, or foreign persons, or international terrorist activities," and counterintelligence, which "means information gathered, and activities conducted, to protect against espionage, other intelligence activities, sabotage, or assassinations conducted by or on behalf of foreign governments or elements thereof, foreign organizations, or foreign persons, or intcrnational terrorist activities." National Security Act of 1947, § 3(1)-(3) (as amended), 50 U.S.C. § 401a(1)-(3) (2006). Some experts define intclligence much more broadly, as information or "what decision makcrs need to know before choosing a course of action." Harry Howe Ransom, Congress and the Intelligence Agencies, 32 Proc. Acad. PoL. SCI. 153, 154 (1975). As the term is used here, intelligence refers to processed information potentially relevant to national security; it docs not include 
covert operations to gather information or to respond to information that has already been collected and analyzed, among other reasons. ${ }^{25}$

Congressional oversight of the intelligence community is similarly fragmented: seventeen committees, almost all of which existed prior to September 11, 2001, oversee at least one intelligence-related agency. ${ }^{26} \mathrm{Nei}$ ther the House of Representatives nor the Senate has a standing committee specifically devoted to intelligence. ${ }^{27}$ The House Appropriations, Armed Services, Budget, Energy and Commerce, Government Reform, Homeland Security, International Relations, and Judiciary Standing Committees and the House Permanent Select Committee on Intelligence (House Intelligence Committee) all oversee at least some part of the intelligence community. ${ }^{28}$ The House Intelligence Committee, created in 1977, has characteristics of both standing and select committees. ${ }^{29}$ The Committee's members have term limits, but the Committee is able to report legislation to the entire House. ${ }^{30}$ The Senate Appropriations, Armed Services, Budget, Energy and Natural Resources, Foreign Relations, Homeland Security and Governmental Affairs, and Judiciary Standing Committees and the Senate Select Committee on Intelligence (Senate Intelligence Committee) all exercise intelligence-related jurisdiction. ${ }^{31}$ The Senate Intelligence Committee, created in 1976, had, until the start of the 109th

covert operations that use such information or information essentially irrelevant to national security. $C f$. Loch K. Johnson, Secret Agencies: U.S. Intelligence IN A Hostile World 7 (1996) ("Regardless of how the term is used-as product, process, mission, or organization-intelligence is widely considered America's 'first line of defense."”).

25. WMD REPORT, supra note 10 , at 585.

26. Bert Chapman, Researching National. Security and Intelligence Policy 234-43 (2004). Congress is not the only overseer of administrative agencies. Agencies serve the President, who nominates their leaders, as well as members of Congress, who delegate work to agencies. Agencies also operate under potentially piercing oversight by interest groups and the courts. In microeconomic terms, government bureaucracies essentially function as agents trying to please multiple principals. This Article focuses on congressional oversight of the intelligence community because almost all of the reforms relevant to oversight proposed after September 11,2001 emphasize the Legislative Branch. $C f$. WMD REPORT, supra note 10, at 336 (recommending improvements in oversight within the Executive Branch).

27. Standing committces are permanent structures that are created by statute or the rules of the House or Senate; select committees are typically temporary structures that do not have legislative powers (i.e., are not able to receive and report out proposed legislation). ROGER H. DAVIDSON \& Walter J. Oleszek, Congress and Its Members 197, 201 (9th ed. 2004).

28. Chapman, supra note 26, at 234-39; see also House Rule X, cl. 1; 9/I I COMmission RePORT, supra note 3 , at 421 .

29. H.R. Res. 658, 95th Cong. (1977); Frederick M. Kaiser, Congress and the Intelligence Community: Taking the Road Less Traveled, in The Postreform Congress 279, 290 (Roger H. Davidson ed., 1992). The Speaker of the House, not the party caucuses, chooses all members of the House Intelligence Committee. S. Rep. No. 103-88, at 7 (1994).

30. S. Rep. No. 103-88, at 5 (1994); KAISER, supra note 15, at 2. Since 2003, the terms of the Committee's top Democrat and top Republican have not been limited. Greg Miller \& Richard Simon, Harman Resists Push Off of Spy Panel, Los Angeles Times, May 18, 2006, at Al, Al0.

31. Chapman, supra note 26, at 239-43; see also Senate Rule XXV, cl. 1; 9/1 I Commission REPORT, supra note 3, at 421. 
Congress, characteristics similar to its House counterpart. ${ }^{32}$ Much of the committee jurisdiction is shared; in other words, more than one congressional committee in each chamber usually oversees a particular component of the intelligence community. ${ }^{33}$ For example, the NSA's program of eavesdropping on telephone conversations involving at least one person within the United States arguably falls within the jurisdiction of at least the House and Senate Armed Services, Intelligence, and Judiciary Committees.

These committees use a variety of mechanisms to oversee the intelligence community. Through the legislative process, committees help structure and fund agencies as well as delegate work to them. They also call agency officials to testify in congressional hearings, launch their own investigations or request the Government Accountability Office (GAO) to evaluate agency programs, or request information through more informal channels such as telephone calls and email. Relevant Senate committees also conduct confirmation hearings for top officials, and all Senators vote on those confirmations. ${ }^{34}$ Most, though not all, congressional oversight is particular (for example, investigating a specific satellite program), rather than general (for example, determining the best counterterrorism policies). Also, many of these committees look not only at actions by the intelligence community, but also at the uses of intelligence by other policymakers.

\section{B. The 9/11 Commission's Proposals for Agency Reorganization}

Congress created the independent, bipartisan National Commission on Terrorist Attacks upon the United States, the 9/I1 Commission, in November 2002 to "conduct an investigation... [into] relevant facts and circumstances relating to the terrorist attacks of September 11, 2001" and to "identify, review and evaluate the lessons learned from the terrorist attacks." ${ }^{35}$ At first, President Bush resisted the Commission's creation; he

32. S. Res. 400, 94th Cong. (1976); S. Res. 445, 108th Cong. (2004); S. Rep. No. 103-88, at 5 (1994); KAISER, supra note 15, at 2. Each party's leader in the Senate chooses the party's members of the Intelligence Committee. S. Rep. No. 103-88, at 7 (1994).

33. See Gregory F. Treverton, Intelligence: Welcome to the American Government, in A Question of Balance: The President, the Congress and Foreign Policy 70, 87-88, 94 (Thomas E. Mann ed., 1990). The Intelligence Committees do have "exclusive authorizing and legislative powers" for the CIA and the National Foreign Intelligence Program. Unlike the Senate Intelligence Committee, the House Intelligence Committee also has jurisdiction over "tactical intelligence and intelligence-related activities." KAISER, supra note 15, at 2 (internal quotation marks omitted); see also S. Rep. No. 103-88, at 11 (1994); BEST, supra note 21, at 7. But neither committee has jurisdiction over appropriations. 9/I I COMMIssion REPORT, supra note 3, at 103. The Intelligence Committees reserve committee seats for members of the other committees with major jurisdiction over the intelligence community (Appropriations, Armed Services, Foreign Affairs/International Relations, Judiciary). KAISER, supra note 15 , at 3 . The House reserves one seat for each such committee; the Senate rescrves two seats (one for each political party). Id.

34. See DA viDSON \& OLESZEK, supra note 27, at 324-343.

35. Intelligence Authorization Act for Fiscal Year 2003, Pub. L. No. 107-306, § 604(a)(1)(A), (a)(2), 1 I6 Stat. 2383, 2383, 2409-10 (2002). 
eventually acquiesced in the face of tremendous pressure from members of Congress and the victims' families. ${ }^{36}$ The Commission's best-selling, unanimous report, issued July 22, 2004, began with a harrowing narrative of the terrorists' preparations for their attacks and the subsequent devastation. ${ }^{37}$ The Report concluded with five major proposals for change:

(1) "unifying strategic intelligence and operational planning against Islamic terrorists across the foreign-domestic divide with a National Counterterrorism Center";

(2) "unifying the intelligence community with a new National Intelligence Director";

(3) "unifying the many participants in the counterterrorism effort and their knowledge in a network-based information-sharing system that transcends traditional governmental boundaries";

(4) "unifying and strengthening congressional oversight to improve quality and accountability"; and

(5) "strengthening the FBI and homeland defenders." 38

These recommendations reflect onc view of how Executive Branch functions should be carried out and how Congress should oversee them. The Commission's perspective emphasizes unification and elimination of duplication, and contrasts with the decentralized and often redundant practices of both branches of government prior to the attacks.

The Commission recommended that intelligence gathering and analysis be unified under a single director with substantial authority rather than conducted by multiple units that ultimately answer to different directors. In the Commission's words,

[t]he current position of Director of Central Intelligence should be replaced by a National Intelligence Director with two main areas of responsibility: (1) to oversee national intelligence centers on specific subjects of interest across the U.S. government and (2) to manage the national intelligence program and oversee the agencies that contribute to it. ${ }^{39}$

It also recommended that counterterrorism intelligence and operations be combined in a national center. ${ }^{40}$ The Commission urged, in addition, that congressional oversight of the intelligence bureaucracy be centralized under either a joint House-Senate intelligence committee or a single

36. Todd S. Purdum, The Next Hard Step, N.Y. Times, July 23, 2004, at Al.

37. 9/1 I COMmission Report, supra note 3, at 1-338. According to a senior advisor to the 9/1 I Commission, the Commission's leaders wanted an unanimous report and achieved consensus through various compromises and votes. Ernest R. May, American Political History Seminar Series, Institute of Governmental Studies, University of California, Berkeley (Mar. 24, 2006).

38. 9/1 I COMMISSION REPORT, supra note 3, at 399-400.

39. Id. at $4 \mathrm{I} 1$.

40. Id. at 403 . 
committee in each chamber. ${ }^{41}$ The Commission also concluded that members on the joint intelligence committee should not have term limits so that they could build expertise. ${ }^{42}$ In short, the Commission called for a fundamental organizational shift in the federal government's national security intelligence work, from multiple, weakly coordinated intelligence bureaucracies and congressional overseers to a largely unified bureaucracy with just one or two congressional overseers.

The 9/11 Commission disbanded on August 2I, 2004. ${ }^{43}$ Commission members then established a private nonprofit organization, the 9/11 Discourse Project, to push for implementation of their recommendations; that Project terminated, by design, at the end of $2005 .{ }^{44}$ It is unusual for an official government commission to transform itself into a private advocacy group ${ }^{45}$ but the Commission's members wield unusual authority. Before the Commission released its report but after its high-profile hearings, its public approval was at $61 \%$ and barely varied by party affiliation. ${ }^{46}$ Nearly a year later, the New York Times editorial page called the Commission "the most effective, and most trusted, voice on national security since Sept. 11, 2001."47

\section{Current Organization of the Intelligence Community}

The Intelligence Reform Act, signed by President Bush approximately five months after the issuance of the 9/11 Commission's Report, made

41. Id. at 420 . The $9 / 11$ Commission made the same recommendation regarding congressional oversight of homeland security, an area this paper does not directly address, except as it relates to intelligence reform. Id. at 421 .

42. Id.

43. 9/11 Public Discourse Project, Overview, available at http://www.9-11pdp.org/ about/index.htm; see also Intelligence Authorization Act for Fiscal Year 2003, Pub. L. No. 107-306, $\S 610(\mathrm{c}), 116$ Stat. 2383, 2413 (2002) (allowing sixty days after issuance of report for Commission to terminate).

44. Philip Shenon, 9/II Panel Members Form Group to Press Recommendations, N.Y. TIMEs, Sept. 19, 2004, at A35; 9/11 Public Discourse Project, supra note 43.

45. The only other example appears to be the Milton S. Eisenhower Foundation, a continuation of the National Advisory Commission on Civil Disorders (the Kerner Riot Commission) and the National Commission on the Causes and Prevention of Violence (the National Violence Commission). See Summary, http://www.eisenhowerfoundation.org/aboutus/mission.html; E-mail from Adam Klein, 9/11 Public Discourse Project, to Casey Roberts (Oct. 19, 2005) (on file with author). Members of federal commissions, however, frequently do continue participating in relevant policy debates after the commissions have ended. Thomas R. Wolanin, Presidential advisory Commissions: Truman to NiXON I83 (1975).

46. Pew Research Center for the People and the Press, $9 / 1$ l Commission has Bipartisan SuPPort (July 20, 2004); Philip Shenon, Sept. 11 Panelists Seeking U.S. Data on Terror Risks, N.Y. Times, June 6, 2005, at Al.

47. Reliable Voices for Reform, N.Y. TIMES, June 9, 2005, at A26; but cf. Douglas Jehl, 9/11 Panel Explains Move on Intelligence Unit, N.Y. TIMEs, Aug. 13, 2005, at A9 (noting criticism of Commission for not reporting that the Defense Department's "Able Danger" program had identified Mohammed Atta as a possible terrorist before the attacks). 
substantial changes to the intelligence community's structure. ${ }^{48}$ The statute did not meaningfully affect congressional committee jurisdictions concerning intelligence. It created a new cabinet-level DNI, who "serve[s] as head of the intelligence community" and "act[s] as the principal adviser to the President, to the National Security Council, and to the Homeland Security Council for intelligence matters." 49 The Director of the CIA may not serve simultaneously as DNI. ${ }^{50}$ Many commentators have called the creation of the DNl the largest organizational change in the intelligence community since the creation of the CIA. ${ }^{51}$

Among other tasks, the DNI must set priorities for existing agencies and "ensure the elimination of waste and unnecessary duplication within the intelligence community." 52 The DNI also must oversee the new National Counterterrorism Center (NCTC), which is to serve as the main agency "for analyzing and integrating all intelligence...pertaining to terrorism and counterterrorism, excepting intelligence pertaining exclusively to domestic terrorists and domestic counterterrorism," and which is " $[\mathrm{t}]$ o conduct strategic operational planning for counterterrorism activities, integrating all instruments of national power, including diplomatic, financial, military, intelligence, homeland security, and law enforcement activities within and among agencies." 53

The Bush Administration seemed to struggle to convince a qualified person to take the DNI job. ${ }^{54}$ It took almost two months after signing the intelligence reform legislation for President Bush to announce that he had selected John Negroponte, ambassador to lraq and former ambassador to the United Nations, as the first DNI. ${ }^{55}$ Nearly two more months passed before the Senate confirmed Negroponte. ${ }^{56}$ Negroponte promised the Senate Intelligence Committee that he would "push the envelope" in interpreting

48. IRA, 1 I 8 Stat. 3638.

49. Id. $\S 10 \mathrm{I}$, I18 Stat. at 3644 .

50. Id.

51. See, e.g., RICHELSON, supra note 17, at 17; BEST, supra note 21 , at 1 .

52. 1RA, § 1011, 118 Stat, at 3649-50.

53. Id. $\S \S 1011,1021,118$ Stat. at 3649,3673 . The NCTC Director "may not direct the execution of counterterrorism operations." Id. $\S 1021$.

54. See Douglas Jehl, C.I.A. Chief Under First Bush Says He Has Declined New Job, N.Y. TImes, Feb. 1, 2005, at A16; Richard A. Posner, Important Job, Impossible Position, N.Y. TImes, Feb. 9, 2005, at A23; Scott Shane \& Elisabeth Bumiller, Delay in Naming of Spy Chief is Said to Hurt Terrorism Fight, N.Y. TiMES, Feb. I7, 2005, at A27.

55. Douglas Jehl \& Elisabeth Bumiller, Bush Picks Longtime Diplomat for New Top Intelligence $J o b$, N.Y. TimEs, Feb. 18, 2005, at A1.

56. Scott Shane, Negroponte Confirmed as Director of National Intelligence, N.Y. TimEs, Apr. 22,2005 , at A19. 
his authority as DNI. ${ }^{57}$ President Bush did not name a Director of the NCTC until June 2005..$^{58}$

The Intelligence Reform Act appears to transfer considerable budgetary and personnel authority from the nation's intelligence agencies to the DNI, but in reality it leaves some of the DNI's powers vague. The intelligence community's budget until recently has been divided into three components: the National Intelligence Program (NIP), the Joint Military Intelligence Program (JMIP), and Tactical Intelligence and Related Activities (TIRA). ${ }^{59}$ The Act mandates that the DNI "develop and determine" the government's annual budget for the NIP and present that budget to the President for approval (along with any dissenting views from specified officials in the intelligence community). The DNI then must direct the allocation of its appropriations through Department leaders who oversee intelligence agencies, including, among others, the Secretaries of Defense, Energy, Treasury, and Homeland Security. ${ }^{60}$ The DNI can transfer funds within the NIP, however, only after obtaining Office of Management and Budget (OMB) approval and consulting with relevant agencies. ${ }^{61}$ The DNI must "participate in the development" of the annual budgets for the JMIP and TIRA, but the Secretary of Defense leads that process. ${ }^{62}$ Furthermore, the DNI has no ability to transfer funds within the JMIP; the Secretary of Defense need only consult the DNI before transferring funds. ${ }^{63}$

The Act similarly appears to have centralized personnel authority in the DNI, but, again, the actual extent of the DNI's authority is unclear. After obtaining approval from the OMB, the DNI can transfer up to 100 intelligence community employees to a new intelligence center (such as the NCTC), and can move employees from one intelligence agency to another for up to two years. ${ }^{64}$ The DNI also has significant appointment power over top intelligence agency officials. He must recommend a candidate to the

57. Douglas Jehl, Nominee Promises Tighter Control Over U.S. Intelligence Agencies, N.Y. Times, Apr. 13, 2005, at A14.

58. Jim VandeHei, Bush Taps Admiral as Chief of Counterterrorism Center, Wash. Post, June 11, 2005, at A4 (retired Vice Admiral and WMD Commission Executive Director John Redd).

59. WMD REPORT, supra note 10, at 349 n.5, 587-88. The intelligence community budget is classified, but it is widely reported that it is approximately $\$ 40$ billion and that the Department of Defense consumes approximately $80 \%$ of it. See, e.g., Douglas Jehl, Debate on Secret Program Bursts into Open, N.Y. TIMES, Dec. 10, 2004, at A24; Douglas Jehl, Nominee Vows Tighter Control Over U.S. Intelligence Agencies, N.Y. TIMES, Apr. 13, 2005, at Al4. In November 2005, a top intelligence official revealed that the community's budget was $\$ 44$ billion. Scott Shane, Official Reveals Budget for U.S. Intelligence, N.Y. TIMES, Nov. 8, 2005, at A18.

60. IRA, $\S 1011,118$ Stat. at $3644-45$.

61. Id. $\S 1011,118$ Stat. at $3646-47$.

62. Id. $\$ 1011,118$ Stat. at 3645 .

63. Id. $\$ 1011,118$ Stat. at 3646 .

64. Id. $\S 1011,118$ Stat. $3647-48$. The DNl must promptly notify certain congressional committees and follow procedures to be developed with relevant agencies. Id. 
President when the Principal Deputy DN1 or CIA Director positions are vacant. For a variety of other positions, the DNI's concurrence is necessary for the responsible cabinet secretary to appoint someone or to recommend a candidate for the President to appoint. ${ }^{65}$

How these budgetary and personnel provisions of the lntelligence Reform Act will actually operate in practice and, particularly, whether they will unify the intelligence community is uncertain. ${ }^{66}$ To garner sufficient support from House Republicans to get the bill out of committee and up for a vote by the entire chamber, a provision was added to protect the Secretary of Defense's ultimate control over intelligence agencies located within the Defense Department, including the DlA, NSA, and NRO. ${ }^{67}$ Specifically, the Act requires the President to promulgate guidelines that constrain the DN1 to act "in a manner that... does not abrogate the statutory responsibilities of the head of the departments of the United States Government concerning such departments . . . "68

DNI Negroponte has built up a large staff that is scheduled to exceed 1500 people, and his office's budget is nearing $\$ 1$ billion-by some calculations, five times what had been spent on management of the intelligence community prior to the Intelligence Reform Act. ${ }^{69}$ In his first annual progress report to Congress in May 2006, Negroponte explained that he had used his NIP budget authority to resolve a long-standing conflict over the acquisition of certain imaging technology; to better assign responsibility for one type of technically derived intelligence, measurement and signature intelligence; and to supervise major purchases by the intelligence community. ${ }^{70}$ Negroponte also endorsed the creation of the Military lntelligence

65. Those positions include: Director of the NSA, Director of the NRO, Director of the NGIA, Assistant Secretary of State for Intelligence and Research, Dircetor of the Office of Intelligence of the Department of Energy, Director of the Office of Counterintelligence of the Department of Energy, Assistant Secretary of the Treasury for Intelligcnce and Analysis, Executive Assistant Director for Intelligence of the FB1, and Assistant Secretary of Homeland Security for Information Analysis. Id. $\S 1014,118$ Stat. at 3664 .

66. See WMD REPORT, supra note 10, at 315; Can spies be made better? EconomisT, Mar. 19, 2005, at 29; Posner, supra note 54, at A23.

67. Some House Rcpublicans expressed concern that the DNI, as created by the Senate, could usurp the Defense Department's authority, resulting in the potential endangerment of soldiers in battle. Phillip Shenon, With Recess Imminent, Intelligence Bill Remains Tied Up, N.Y. TIMEs, Dec. 6, 2004, at A21.

68. IRA, § 1018, I18 Stat. at 3670; see also Philip Shenon, House Approves Broad Overhaul of Intelligence, N.Y. TimEs, Dec. 8, 2004, at A1. As of July 2006, these guidelines had not been drafted. BEST, supra notc 21 , at 8 .

69. Report of Senate Select Committee on Intelligence to Accompany 3237, at $\S 105$; Gail Russell Chaddock, Congress Takes Hard Look at 9/II Reforms, Christian Sci. Monitor, Apr. 28, 2006, at 3; see also David Ignatius, Fix the Intelligence Mess, WASH. PosT, Apr. 21, 2006, at A23. The size has not gone unnoticed by members of Congress who are trying to impose various restrictions on the DNl's growth. Chaddock, supra, at 3.

70. Office of the Director of National Intelligence, Report on the Progress of the Director OF National INTElligence IN IMPLEMENTING THE "1NTELligence Reform and Terrorism Prevention ACt of 2004," at 3 (May 17, 2006) [hereinafter Progress] 
Program, which would combine the JMIP and most of TIRA. ${ }^{71}$ The DNI also reported the transfer of seventy-two analyst positions from various intelligence agencies to the NCTC. ${ }^{72}$

Despite these accomplishments, the DNI has repeatedly clashed with the Defense Department. During his confirmation hearing to become CIA Director, Deputy DNI General Michael Hayden conceded that the DNI and the Defense Department had "skirmishes over staff." November 2005, Secretary of Defense Rumsfeld promulgated a directive that mandates the concurrence of the head of the Department's intelligence efforts before the DNI can transfer any Defense Department personnel. ${ }^{74}$ The Defense Department also has increased its spy missions under the Special Operations Command, which reports to Secretary Rumsfeld and is not under the DNI's control. ${ }^{75}$ The DNI reportedly has also fought with the CIA over personnel transfers. ${ }^{76}$ The House Intelligence Committee's initial assessment of the DNI's work implementing the Intelligence Reform Act was quite critical, finding inadequate prioritization, insufficient coordination with the Committee, problems with information sharing, and unplanned duplication. ${ }^{77}$

The WMD Commission's report, issued after the Intelligence Reform Act was enacted, takes into account the new bureaucratic structures established by the Act. ${ }^{78}$ Of relevance here, the White House endorsed the WMD Commission's recommendation of a National Counterproliferation Center (NCPC) under the DNI to coordinate intelligence collection and analysis concerning proliferation issues such as weapons of mass

71. Id. at 6; BEST, supra note 21, at 7 .

72. Office of the Director of National Intelligence, Progress, supra note 70 , at 8. According to the DNI, he has made "greatest use of [his] authorities in the personnel arena." OFFICE OF the Director of National Intelligence, ODNI Progress Report-WMD Commission Recommendations (Unclassified), at 9 (July 27, 2006) [hereinafter WMD Commission RECOMMENDATIONS]

73. Eric Schmitt, Clash Foreseen Between C.I.A. and Pentagon, N.Y. Times, May I0, 2006, at AI.

74. Id.

75. Id.; see also Thom Shanker \& Scott Shane, Elite Troops Get Expanded Role on Intelligence, N.Y. Trmes, Mar. 8, 2006, at Al.

76. Mark Mazzeti, Exit of Chief Viewed as Move to Revamp C.I.A., N.Y. TIMEs, May 7, 2006, at AI.

77. House Permanent Select Committee on Intelligence Subcommittee on Oversight, Initial Assessment on the Implementation of the Intelligence Reform and Terrorism Prevention ACt of 2004, at 3, 6, 7, I7-I8 (July 27, 2006).

78. Like the 9/I1 Commission's Report, the WMD Commission's Report received national attention. See, e.g., David E. Sanger \& Scott Shane, Panel Criticizes C.I.A. For Failure On Iraq Weapons, N.Y. TIMES, Mar. 29, 2005, at A1. In total, the WMD Commission announced seventy-four recommendations, five of which were classified. See WMD REPORT, supra note 10, at 563, 557-77. After a ninety-day review of the WMD Commission's report, the Bush Administration stated that it accepted almost all of the report's recommendations. Douglas Jehl, Bush to Create New Unit in F.B.I. for Intelligence, N.Y. TIMES, June 30, 2005, at A1. 
destruction and connected delivery systems. ${ }^{79}$ The DNI has since established the NCPC as well as selected "mission managers" for Iran and North Korea. ${ }^{80}$

According to media reports, the White House, however, rejected the Commission's classified recommendation to transfer particular covert functions from the CIA to the NCTC and NCPC, which would have ultimately provided the Defense Department with more authority. ${ }^{81}$ The White House also did not adopt the Commission's recommendation for a human intelligence directorate to coordinate human intelligence efforts, but instead created a new CIA position to resolve conflicts among CIA, Defense Department, and FBI operations. ${ }^{82}$ In addition, the White House announced it would work with Congress to create a new assistant attorney general position at the Department of Justice to consolidate intelligence and national security functions. ${ }^{83}$

Most significant, the President ordered the creation of a National Security Service (NSS) within the FBI, which will combine the agency's national security responsibilities (intelligence collection, counterintelligence, and counterterrorism) and will be "subject to the coordination and budget powers" of the DNI. ${ }^{84}$ The NSS chief will report to the DNI and the Director of the FBI. ${ }^{85}$ These changes generally garnered positive reactions. The New York Times editorial page concluded, "They are a rebuff to Defense Secretary Donald Rumsfeld's attempts to seize control of intelligenee gathering. And they give real power to the new director of national intelligence, John Negroponte." ${ }^{\text {"66 }}$ The American Civil Liberties

79. Jehl, supra note 78 , at Al.

80. Office of the Director of National 1Ntelligence, Progress, supra note 70, at 8; Office of the Director of National Intelligence, WMD Commission Recommendations, supra note 72 , at 1,2 .

81. Jehl, supra note 78, at A1. As part of the DNI restructuring, the CIA and the Defense Department apparently reached a new agreement to avoid conflict and overlap in intelligence collection and analysis. Walter Pincus, CIA, Pentagon Seek to Avoid Overlap, WASH. Post, July 4, 2005, at A2. Growing Defense Department intelligence activity, within the United States and abroad, was seen as creating the need for a new agreement. Id.

82. Jehl, supra note 78, at Al. Aecording to two senior intelligence officials, this ClA office, however, will have only limited power, allowing the Defense Department and the FBI to conduct human intelligence operations without overarching control by the CIA. Douglas Jehl, Little Authority for New Intelligence Post, N.Y. TIMEs, Oct. 14, 2005, at A16. The ClA has also established its National Clandestine Service. Office of the Director of National Intelligence, WMD Commission RECOMMENDATIONS, supra note 72 , at 3.

83. Jehl, supra note 78, at A1. Edgar now works for the DN1 on civil liberties issues. Scott Shane, Watching the Watchers: An Intelligence Official Works to Keep Agencies in Bounds, N.Y. Times, July 25, 2006, at A15.

84. Id.

85. Id. The DNI must approve the FBI's choice for the NSS chief. Dan Eggen \& Walter Pincus, Spy Chief Gets More Authority over FBI, WASH. Post, June 30, 2005, at A1. On August 12, 2005, the FB1 named Gary M. Bald, a senior FBI offieial, as head of the new division. Eric Lichtblau, F.B.I. Picks Chief for New National Security Unit, N.Y. Times, Aug. 13, 2005, at A12.

86. Reforms at the F.B.I. and Justice, N.Y. TIMEs, July 1, 2005, at A16. 
Union (ACLU) has opposed the changes. Timothy Edgar, then Immigration and National Security Legislative Counsel for the ACLU, commented, "The FBI is effectively being taken over by a spymaster who reports directly to the White House. . . It's alarming that the same person who oversees foreign spying will now oversee domestic spying, too."

The significance of these shifts in the structure of the intelligence community is disputed. At least one prominent national security scholar believes that the Intelligence Reform Act has not produced substantial changes desired by the Act's proponents. ${ }^{88}$ In its October 2005 report on the status of the 9/11 Commission's recommendations, the 9/11 Public Discourse Project announced that while Congress had "fulfilled" the DNI and NCTC recommendations, the Executive Branch had made only "some progress" on organizational reform. ${ }^{89}$ In its December 2005 final report, the Project noted that NCTC "does not yet have sufficient resources or personnel to fulfill its intelligence and planning role"; the Commissioners also called for the DNI "to exercise his authorities boldly to smash stovepipes, drive reform, and create a unity of effort."

\section{Current Organization of Congressional Oversight}

While Congress and the Administration have made at least some serious efforts to reorganize the intelligence community, Congress has made little effort to reorganize its overlapping committee oversight of the intelligence community. ${ }^{91}$ Given members' desires to maintain their committee turf, this is not surprising. The one noteworthy attempt at reorganization occurred in October 2004, when the Senate enacted a series of internal changes. The Senate ended its eight-year term limits for members of its Intelligence Committee. It also elevated its Intelligence Committee to category "A" status; generally Senators can serve on no more than two " $A$ " committees. In addition, it voted to create an Oversight Subcommittee of the Intelligence Committee and establish an Intelligence Subcommittee of its Appropriations Committee. Finally, it changed the name of its Governmental Affairs Committee to the Committee on Homeland Security and Governmental Affairs. ${ }^{92}$ The New York Times editorial page dismissed

87. Eggen \& Pincus, supra note 85 , at $\mathrm{A} 7$.

88. Scott Shane, Year Into Revamped Spying, Troubles and Some Progress, N.Y. Times, Feb. 28, 2006, at A12 (quoting Amy Zegart).

89. $9 / 1$ i Public Discourse Project, Final Report on 9/i i Commission Recommendations 2 (Dec. 5, 2005).

90. Id. at 2 .

91. See Unfinished Intelligence Work, N.Y. TIMES, Oct. 11, 2004, at A22.

92. S. Res. 445, 108th Cong. (2004); WMD REPORT, supra note 10, at 338 n.5; PAUL S. Rundquist \& Christopher M. Davis, S.Res. 445: Senate Committee Reorganization for Homeland Security and Intelligence Matters, CRS Report RS2 I955, at 1-2 (Oct. 15, 2004). The House Intelligence Committee still has six-year term limits for its members. Marvin C. Ott, 
these reforms as "cosmetic." 93 As of July 2006, the Appropriations Subcommittee on Intelligence had not been established. ${ }^{94}$

After September 11, 2001, the House created a permanent Homeland Security Committee, but did not provide it exclusive jurisdiction over any issue, including intelligence matters. ${ }^{95}$ The House Intelligence Committee also created a subcommittee devoted to oversight. ${ }^{96}$ In October 2004, Representative Carolyn Maloney (D-NY) proposed that the House make substantial changes to its Intelligence Committee, including shifting its status from a select committee to a standing committee and providing it exclusive jurisdiction over the intelligence community, including components within the Department of Defense. ${ }^{97}$ Representative Maloney's proposal has not been voted out of committee. In contrast, some Representatives want to broaden committee jurisdictions over intelligence. In July 2006, Representatives Jeff Flake (R-AZ) and Adam Schiff (D-CA) introduced a bill that would require the House Intelligence Committee to disclose considerable classified information to at least eight other House committees. ${ }^{98}$

Congress also has not implemented the WMD Commission's suggestions regarding congressional oversight. In its final report, the Commission made several concrete proposals, including a recommendation that Congress establish an intelligence appropriations subcommittee and that the Senate Intelligence Committee be given the same authority over joint military intelligence programs and tactical intelligence programs that the House Intelligence Committee now has. ${ }^{99}$ Others have suggested that Congress create a five-year nonpartisan commission with "continuing review" authority to oversee "extraordinary measures" taken by the intelligence community to protect national security. ${ }^{100}$

Partisanship and the Decline of Intelligence Oversight, 16 INT'L J. INTELLIGENCE \& COUNTERINTELLIGENCE 69, 87 (2003).

93. Unfinished Intelligence Work, supra note 91 , at A22.

94. BEST, supra note 2I, at 8.

95. 9/1 I Public Discourse Project, supra note 89, at 8-9. The Center for Strategic and International Studies and the Business Executives for National Security found that seventy-nine congressional committees and subcommittecs have "some amount of jurisdiction over various aspects of homeland security." CSIS-BENS TASK FORCE ON CONGRESSIONAL OVERSIGHT OF THE Department of Homeland Security, Untangling the Web: Congressional Oversight and the Department of Homeland Security 2 (Dec. 10, 2004).

96. 9/I I Public Discourse Project, supra note 89, at 8.

97. H.R. Res. 837, 108th Cong. (2004).

98. H.R. Res. 5954, 109th Cong. (2006). The eight committees listed are: Appropriations, Armed Services, Energy and Commerce, Financial Services, Govemment Reform, Homeland Security, International Relations, and Judiciary. Id. at $\S 2$. Financial Services is not typically listed as a committee with jurisdiction over intelligence. See supra note 28 and accompanying text.

99. WMD REPORT, supra note 10, at 20.

100. Philip B. Heymann \& Juliette N. Kayyem, Preserving Security and Democratic Freedoms in the War on TERRor 120-21 (2004). 
Before dissolving in late 2005, the 9/1 1 Public Discourse Project lobbied for enactment of its proposals on congressional committee structure. It called for the Intelligence Committees to be given appropriating authority or, in the alternative, for the Appropriations Committees to create subcommittees for intelligence and for the House Intelligence Committee to end the term limits for its members. ${ }^{101}$ In its final "report card," the Project gave Congress a " $\mathrm{D}$," having concluded that the legislative chambers "have taken limited positive steps, including the creation of oversight subcommittees" but that oversight "is still undermined by the power of the Defense Appropriations subcommittees and Armed Services committees." 102

\section{II}

\section{A Framework For Evaluating \\ Proposed Organizational Changes}

Fundamental changes to the structure of the intelligence community and congressional oversight raisc key administrative and constitutional law issues. These structural choices affect national security as well as core democratic values, including civil liberties, transparency, and accountability. The choices involve a public policy area that is, in certain ways, typical and, in other ways, unique. Intelligence work requires great secrecy for its effectiveness, yet occurs within a democratic government. Figure 1 illustrates four combinations of structural choices, which represent poles on two continuums.

Prior to September 11, 2001, the structure of the intelligence community and its congressional overseers could be described as decentralized, redundant agencies and decentralized, redundant oversight (the top left box below). The 9/11 Commission recommended a shift to centralized, unified agencies and centralized, unified oversight (the bottom right box). Judge Posner, by contrast, generally supports decentralized, redundant agencies and centralized, unified oversight (top right box) ${ }^{103}$ After the Intelligence Reform Act, the current structure is more one of centralized, unified agencies and decentralized, redundant oversight (bottom left box). Unification here typically implies nonredundancy; at the least, it implies less

101. 9/1 i Public Discourse Project, supra note 89, at 8.

102. Id. at 3 .

103. PoSNER, supra note 1, at 36, 43, 63, 97, 140. Posner, however, does support restructuring of the FBI; he favors the creation of a. unified domestic intelligence agency with no law-enforcement duties, similar to the United Kingdom's MI5. Id. at 173-80, 206; Garicano \& Posner, supra note 1, at 153, 167. He also favors some coordination by the National Security Adviser, particularly on the budget, "to make sure all bascs are covered." Posner, supra note 1, at 11; see also PoSNER, supra note 1 , at 148 . 
redundancy than a decentralized, redundant structure. ${ }^{104}$ What option (or mixture of options) is optimal?

Figure 1

\section{Congressional oversight}

\begin{tabular}{|c|c|c|c|}
\hline & & $\begin{array}{l}\text { Decentralized/ } \\
\text { redundant (multiple } \\
\text { committees) }\end{array}$ & $\begin{array}{l}\text { Centralized/ } \\
\text { unified (single } \\
\text { committee in } \\
\text { each chamber or } \\
\text { single joint } \\
\text { committee) }\end{array}$ \\
\hline \multirow{2}{*}{$\begin{array}{l}\text { Structure of } \\
\text { intelligence } \\
\text { community }\end{array}$} & $\begin{array}{l}\text { Decentralized/ } \\
\text { redundant } \\
\text { (multiple agencies, } \\
\text { no single executive) }\end{array}$ & $\begin{array}{l}\text { Entirely } \\
\text { decentralized/ } \\
\text { redundant (status } \\
\text { quo before 9/11) }\end{array}$ & $\begin{array}{l}\text { Centralized/ } \\
\text { unified oversight, } \\
\text { decentralized/ } \\
\text { redundant intelli- } \\
\text { gence community } \\
\text { (Posner) }\end{array}$ \\
\hline & $\begin{array}{l}\text { Centralized/ } \\
\text { unified (single } \\
\text { agency or head) }\end{array}$ & $\begin{array}{l}\text { Centralized/unified } \\
\text { intelligence } \\
\text { community, } \\
\text { decentralized/ } \\
\text { redundant oversight } \\
\text { (status quo after the } \\
\text { Intelligence Reform } \\
\text { Act) }\end{array}$ & $\begin{array}{l}\text { Entirely } \\
\text { centralized/ } \\
\text { unified (9/11 } \\
\text { Commission) }\end{array}$ \\
\hline
\end{tabular}

This Part proposes a three-pronged approach for evaluating that question in the intelligence area; this approach can also be applied to any subject of the administrative state. Section II.A examines the effectiveness in enhancing national security (considering both benefits and costs) of redundant and unified structures of the intelligence bureaucracy and congressional oversight. For example, Section II.A considers when redundancy in

104. This Article largely refers to redundancy and decentralization interchangeably. To be certain, it is possible to have decentralized but nonredundant agencies or centralized but redundant agcncies. Assume there are two tasks for an agency to carry out: $x$ and $y$. There could be one agency assigned to perform $x$ and another agency to perform $y$. If those two agencies operate independently of each othcr, we would say that those agencies are decentralized and nonredundant. If the two agencies instead fall under a third agency's control, we would treat the agencies as unified and nonredundant. Alternatively, there could be two scparate agencies, each assigned to perform task $x$. If those agencies operate independently, we would say that the agencies are decentralized and redundant. If a third agency, however, controls thc two agencies, we would treat the two agencies as unified but redundant. Generally, however, decentralized structures display more redundancy than centralized ones. 
bureaucratic delegation and oversight creates optimal outcomes, and when it creates perverse outcomes, in terms of national security. It also considers how the selection of a structure of the intelligence community influences the effectiveness of particular structures of congressional oversight, and vice-versa. Section II.B examines the political and legal feasibility of the options, in terms of structural constitutional law, statutes governing bureaucratic reorganization, and political preferences. Neither intelligence agencies nor congressional committees want to give up power, and even if they can be so convinced, changes to authority of agencies and congressional committees face particular legal constraints. Section II.C analyzes how structural choices regarding the intelligence community and congressional oversight affect core liberal democratic values, including civil liberties, transparency, and accountability.

\section{A. Effectiveness in Enhancing National Security}

In selecting among the structural choices, one consideration is effectiveness in promoting the fundamental goal of enhancing national security. What option or combination of options from Figure 1 would a "national security planner," who cares only about maximizing the protection of national security, net of financial costs for that protection, choose? ${ }^{105} \mathrm{Al}-$ though further theoretical and empirical work must be done, a national security planner likely should prefer a combination of structural choices, redundancy for some tasks and unification for others.

The 9/I I Commission generally took the perspective of a national security planner when calling for more unification and less redundancy in the intelligence community and among the community's congressional overseers. On the benefit side, the Commission contended that unification would improve information sharing and coordination among intelligence agencies, leading to better intelligence. ${ }^{106}$ In addition, the Commission argued that unification would improve the accountability of both the intelligence community and Congress. The Commission believed that, if multiple agencies (or committees) dropped the ball, it would be difficult to hold any one entity accountable. ${ }^{107}$ On the cost side, the Commission argued that redundancy, particularly in the intelligence community, was too expensive to maintain. In its view, removing some of the duplicate "stovepiping," i.e.,

105. I choose to focus on net benefits as a measure of effectiveness because it captures the traditional concept of economic efficiency (i.e., in a perfectly competitive market, the most efficicnt outcome is to produce until the marginal benefit from production equals the marginal cost). To be sure, cost-benefit analysis relies on considerable assumptions. See infra note 192. Subsequent references to maximizing national security incorporate this net benefits meaning.

106. 9/I I COMMission RePORT, supra note 3, at 408-09.

107. Id. at 86, 104-07. 
methods of analyzing or storing intelligence, would free up resources for other tasks. ${ }^{108}$

As a national security planner, the $9 / 11$ Commission, however, may have miscalculated. The proper comparison is not between the benefits of unification and the costs of redundancy, on which the 9/11 Commission focused. Rather, the proper comparison is between the net benefits (benefits minus costs) of unification and the net benefits of redundancy. ${ }^{109}$ Examining only redundancy's costs ignores its significant benefits. ${ }^{110}$

Redundancy has several benefits for achieving an operational goal. First, redundancy may combat "group think." Psychologists have found that "group polarization" increases "if members have a sense of shared identity" and decreases "if members have a degree of flexibility in their views and groups consist of an equal number of people with opposing views." 111 Redundant institutional design may increase diversity in viewpoints if workers identify primarily with their own agency. This could prevent members of the intelligence community from forming a shared identity across agencies, and thereby decrease the risk of "group think."112 This psychological research suggests, for example, that if all members of the intelligence community perceive themselves to be clones of the DNI, deliberation among those members likely will lead to an outcome that is more extreme than the DNI's position because deliberation will not contain any opposing viewpoints.

108. Id. at 401,403 .

109. Redundancy is a broad concept. 1t can describe wholesale duplication (i.e., two entities or individuals perform the same tasks) or partial overlap (i.e., two entities or individuals share at least one task). Allan W. Lcmer, There is More than One Way to Be Redundant, 3 ADMIN \& Soc. 334, 337 (1986). Duplication that does not improve the functioning of the system has been described as "total negative redundancy," duplication that does improve system operability as "total positive redundancy," and overlap as "partial redundancy." Dan S. Felsenthal, Applying the Redundancy Concept to Administrative Organizations, 40 PUB. AdmIN. Rev. 247, 248 (1980). Redundant elements can be used in different ways. Each structure could perform a particular task to completion ("enlightened waste"). Alternatively, each structure could perform a task at a lower level, such that the combination yields a completed task, while having the capacity to perform the entire task alone if the other failed ("stress the survivor"). Or one structure could perform a particular task to completion with the other structure as backup ("mobilizing reserves"). Lerner, supra, at 341-49; see also Felsenthal, supra, at 248. Here, the unit of analysis is an administrative agency or congressional committee, not a group of employees within an agency or members of a Committee, who could also engage in redundant tasks.

110. Martin Landau, Redundancy, Rationality, and the Problem of Duplication and Overlap, 29 Pub. Admin. Rev. 346 (1969) [hereinafter Redundancy]; Martin Landau, On Multiorganizational Systems in Public Administration, 1 J. Pub. AdmIn. Res \& Theory 5 (1991) [hereinafter Public Administration]

111. Cass R. Sunstein, Deliberative Trouble? Why Groups Go to Extremes, 110 YALE L.J. 71,118 (2000).

112. Id. at 105 
Second, redundancy may prevent "capture" of agencies or overseers by particular interest groups, decreasing politicization of intelligence. ${ }^{113}$ If interest groups have objectives that differ from the goal of maximizing national security, capture of agencies or overseers decreases national security effectiveness. One interest group generally will find it more difficult to capture several agencies than a single agency; to wield power over multiple agencies, interest groups may have to work together, which is a costly enterprise for the groups. ${ }^{114}$

Third, if redundancy produces competition, ${ }^{115}$ it may yield better outcomes than coordination. ${ }^{116}$ This is, of course, a fundamental insight of economics: perfect competition produces more socially optimal results than monopolies. Specifically, competitive structures may prevent "pernicious" collusion, particularly when the organizations are similar. ${ }^{17}$ Competition may encourage redundant entities to work harder and more creatively, generating a race to the top in performance; competition may also motivate one entity to correct mistakes made by another entity. ${ }^{118}$ For example, if multiple intelligence agencies are tasked with finding Osama

113. See Bruce D. Berkowitz \& Allan E. Goodman, Best Truth: Intelligence in the INFORMATION AGE 97 (2000); Jean-Jacques Laffont \& David Martimort, Separation of Regulators Against Collusive Behavior, 30 RAND J. Econ. 232, 233-34 (1999).

114. On the other hand, it may be casier for interest groups to capture one large agency than many smaller agencies. See HuLT, supra note 14 , at 8.

115. Although all competitive markets have redundant suppliers, the converse is not necessarily truc: not all redundant structures compete with each other. For example, in the San Francisco Bay area, the Bay Area Rapid Transit (BART) and the Alameda-Contra Costa (AC) Transit District provide some redundant transportation options for commuters: to get from San Francisco to Berkeley, onc can take the BART subway train under the San Francisco Bay or the AC Transit bus over the Bay Bridge. These options also compete with each other; commuters choose between thcm. By contrast, the BART trains themselves havc redundant braking systems, automatic and manual, which do not compete with each other. Cf. Francisco Parisi et al., Two Dimensions of Regulatory Competition, 26 INT'L REV. of L. \& ECON. 55 (2006) (distinguishing overlapping elements that operate concurrently and elements that operate alternatively).

116. Oliver E. Williamson, Corporate Control and Business Behavior 1 10-53 (1970) (comparing "U" and "M" forms of businesses); ElaINE C. KAMARCK, IBM CENTER FOR THE BuSiNESS of Government, Transforming the INTELligence CoMmunity: IMProving the Collection and Management of Information 19 (October 2005) (noting Canon's use of competitive product development teams); Stephanos Bibas, Prosecutorial Regulation, Accountability, and Institutional Design, at 45 (summarizing management literature critical of "excessive corporate hierarchies") (unpublished manuscript on file with author).

117. See Ram T.S. Ramakrishnan \& Anjan V. Thakor, Cooperation versus Competition in Agency, J. L. ECON \& ORG. 248, 249 (1991).

118. See Roberta Romano, Is Regulatory Competition a Problem or Irrelevant for Corporate Governance?, 21 OXFORD REv. ECON. PoL'Y 212, 213 (2005); Andrew B. Whitford, Adapting Agencies: Competition, Imitation, and Punishment in the Design of Bureaucratic Performance, in Politics, Policy, and Organizations: Frontiers in the Scientific Study of Bureaucracy 160, 181-82 (George A. Krause \& Kenneth J. Meier eds., 2003); see also MacKubin Thomas Owens, The Hollow Promise of JCS Reform, 10 INT'L SECURITY 98, 105 (1985) ("Interservice rivalry [in the military] has the beneficial effect of spurring innovation in defense policy and in the development of doctrine and equipment in support of a strategic or tactical approach that may seem irrelevant at the timc."). 
bin Laden, the competition to find him might motivate each agency to achieve more than it would if it were the only agency working to achieve that objective. ${ }^{119}$ In addition, such competition may "make it easier for the organization[s] to adapt to a changing environment." ${ }^{120}$ Alternatively, redundancy may allow for needed cooperation, as certain tasks may require multiple, overlapping entities. ${ }^{121}$

Fourth, redundancy may increase reliability by decreasing the chances of the system failing entirely in certain respects. ${ }^{122}$ Take the classic example of a belt and suspenders for holding up a man's pants. Each accessory independently, with some probability, keeps the pants from falling down. A belt can unlatch or suspenders can snap, however. Together, on average, the accessories should prevent an embarrassing moment more often than either used on its own. For example, if the belt works effectively $90 \%$ of the time, and the suspenders work effectively $75 \%$ of the time, these two devices together should work as well as a system that is effective $97.5 \%$ of the time. ${ }^{123}$ The same reasoning applies to the (far harder) task of finding bin Laden. The more dependent the structures are on each other, the smaller the improvement in reliability; in other words, completely independent but redundant structures yield the greatest increase in reliability. ${ }^{124}$

This reasoning can be applied to administrative agencies: according to bureaucratic redundancy theory, multiple agencies delegated the same task are more likely to complete the task than a single agency. ${ }^{125}$ Examples of such redundant arrangements abound in our governmental system. For example, the federal and state courts are redundant, in that both have jurisdiction over certain claims. ${ }^{126}$ The classic example for the administrative state

119. Further, if each entity faces decreasing returns to scale, i.e., higher average costs for each additional unit of production, then it may be less expensive to split production among several entities than to leave it to one larger entity, depending on the costs of establishing each entity. WILLIAM J. Baumol \& Alan S. Blinder, Economics: Principles and Policy 169 (7th ed. 1997).

120. Garicano \& Posner, supra note 1, at 157.

121. Michael M. Ting, A Strategic Theory of Bureaucratic Redundancy, 47 AM. J. PoL. SCl. 274, 287 (2003).

122. C.F. Larry Heimann, Acceptable Risks: Politics, Policy, and Risky Technologies 9 (1998); Charles Perrow, Normal Accidents: Living with High-Risk Technologies 332 (1999); Betts, Analysis, War, and Decision, supra note 15, at 79; Landau, Public Administration, supra note 110, at 12, 15; Landau, Redundancy, supra note 110, at 350; Todd R. Laporte, High Reliability Organizations: Unlikely, Demanding, and at Risk, 4 J. ContINGENCIES \& CRISIS MGMT 60, 63-64 (1996). Empirical work supports this theory. See, e.g., Jonathan B. Bendor, Parallel Systems: Redundancy IN Government 244-45 (1985); Dan S. Felsenthal \& Eliezer Fuchs, Experimental Evaluation of Five Designs of Redundant Organizational Systems, 21 ADMIN. SCI. Q. 474, 474 (1976); Rowan Miranda \& Allan Lemer, Bureaucracy, Organizational Redundancy, and the Privatization of Public Services, 55 PuB. AdmIN. Rev, 193, 193 (1995).

123. The chance of at least one device working is 0.975 . This is the reciprocal of the chance of both clothing devices failing, which is 0.025 , the product of each device's chance of failure, $(0.1)(0.25)$.

124. See BENDOR, supra note 122 , at 47 .

125. Ting, supra note 121 , at 274 .

126. Cf. Hunter v. Martin's Lessee, 14 U.S. 304, 349-50 (1816) (Story, J.). 
is that each military service employs its own "air force," though any one air force could protect troops on the ground. ${ }^{127}$ Although each air force has been tailored to its service's needs, each likely could be reconfigured to provide much of the same protection as any other. Other agency examples exist. The Federal Trade Commission, an independent regulatory commission, and the Antitrust Division of the United States Department of Justice, a cabinet department, both have authority to enforce antitrust laws. ${ }^{128}$ The Department of Interior's Bureau of Reclamation and the Army Corps of Engineers both have authority over federal water policy. ${ }^{129}$

This reliability advantage has limits, however. The direct extension of logic from engineering to political science is problematic. It ignores "strategic interdependencies" among political agents. ${ }^{130}$ For example, the suspenders do not moderate their effectiveness level based on the actions of the belt-each accessory holds up the pants with the same probability whether the other item worked or failed. Political agents often choose their effort levels strategically, moderating their effort based on the actions of others. ${ }^{131}$ Collective action problems are especially acute when agents have goals similar to those of their principal, the institution delegating work to them. ${ }^{132}$ Thus, in considering how to structure the bureaucracy, one must determine how the organizational benefits as well as the potential costs of redundancy interact with its strategic effects. To the extent that redundant structures foster effort (typically through competition), rather than freeriding, reliability likely is increased, but to the extent that redundant structures permit free-riding, reliability typically is decreased. ${ }^{133}$

Redundant structures have disadvantages as well. First of all, redundancy adds costs. ${ }^{134}$ Classic organizational theory emphasizes this argument. ${ }^{135}$ Martin Landau, a proponent of redundancy in bureaucracy as a

127. Ting, supra note 121, at 275. Cf. id. ("Each service has a somewhat differentiated role; for example, only the Air Force has long-range bombers."). See also Carl H. Bullder, The Masks of War: American Military Styles in Strategy and Analysis (1989).

128. Kylie Cooper \& Adrienne C. Dedjinou, Antitrust Violations, 42 Am. Crim. L. Rev. 179, 208 (2005).

129. BENDOR, supra note 122, at 9-15. See also Duplication, Overlap, and Fragmentation in Government Programs: Hearing Before Senate Comm. on Governmental Affairs, 104th Cong. (1995) (detailing agency overlap in national statistics, food safety, employment training, income support, and early childhood programs).

130. Ting, supra note 121 , at 275 .

131. Id.

132. Id. at 276 .

133. C.F. Larry Heimann, Different Paths to Success: A Theory of Organizational Decision Making and Administrative Reliability, 5 J. PuB. AdmIN. Res. \& TheORY 45, 46, 70 (1995) (arguing that reliability can be increased through changes to an entire system or to components of that system); Miranda \& Lerner, supra note 122, at 194.

134. BENDOR, supra note 122 , at 29 ; Hammond, supra note 16 , at 15; Miranda \& Lemer, supra note 122 , at 196 .

135. Craig W. Thomas, Reorganizing Public Organizations: Alternatives, Objectives, and Evidence, 3 J. Pub. Admin. Research \& Theory 457, 460 (1993). 
means to increase reliability, acknowledges that the costs of redundancy might be "prohibitive" but argues that because the "probability of failure in a system decreases exponentially as redundancy factors are increased," costs likely will be "quite manageable." ${ }^{136}$ Landau does not, however, consider that redundant agencies may act strategically, shirking their duties but still requiring substantial funds.

There is also a subtler version of this efficiency argument: if there are increasing returns to scale (i.e., the average cost of each additional unit is decreasing), ${ }^{137}$ or if the fixed costs of establishing additional entities are sufficiently high, combining functions in one entity is more efficient. ${ }^{138}$ For example, assume that satellite imaging has increasing returns to scale: the average cost of each additional image declines as the number of images increases (perhaps because the fixed cost of equipment gets divided over a greater number of images, while the marginal cost of producing each additional image is constant). It is better for one agency to invest in and maintain satellite equipment for images than for multiple agencies to do so. Costs for redundant structures also represent lost funds for other tasks. ${ }^{139}$ In other words, if resources are fixed, redundant structures impose additional opportunity costs..$^{140}$

Second, redundancy may actually decrease reliability in some cases. As suggested above, redundant entities may "shirk off unpleasant duties because it is assumed that someone else will take care of the problem."141 Knowing that others are working on the same problem, each actor may expend less effort or attention on it. Even a partial reduction in attention or effort by each redundant entity may result in lower reliability than that would exist with a single entity. This argument presumes that entities do not suffer sufficiently adverse consequences from free-riding. If only one entity is tasked with preventing a catastrophic but low-probability event, that entity generally faces greater consequences for failing than if more than one agency has the same task.

Third, redundancy may undermine the quality of agency or committee products or decisions in a variety of ways. To start, in contrast to the argument that redundancy can produce more moderate positions, redundant structures may actually increase group polarization within each structure; a unified, more heterogeneous structure may produce more moderate

\footnotetext{
136. Landau, Redundancy, supra note 110 , at 350.

137. BAUMOL \& BLINDER, supra note 119 , at 169.

138. BENDOR, supra note 122, at 29; Hammond, supra note 16, at 15-16 n.14; but cf. PoSNER, supra note 1 , at 138 .

139. BENDOR, supra note 122 , at 30 .

140. Id.

141. Scott D. Sagan, The Problem of Redundancy Problem: Why More Nuclear Security Forces May Produce Less Nuclear Security, 24 Risk ANALYSIS 935, 939 (2004) (describing how more witnesses to a crime could result in a lower probability that the police are notified if witnesses think the chance that someone else will report the crime increases with the number of witnesses).
} 
positions. ${ }^{142}$ Imagine that each intelligence agency has a strong culture. If each agency works alone on a problem, agencies may produce quite polarized decisions; if members from disparate intelligence cultures join together on a particular problem, they may produce better decisions. Further, redundant elements may "race to the bottom" in terms of the quality of their outputs, so that all elements operate at the lowest "level" of any the elements. ${ }^{143}$

Fourth, competition among agencies or committees may prevent critical cooperation among entities. In fighting for resources, for example, each redundant element presumably puts its own interests before the larger goal of protecting national security. ${ }^{144}$ Further, competing entities may create undesired interference. For example, if two agencies are conducting covert operations in the same place without coordinating with each other, one agency's efforts may harm the other's if they are going after the same confidential sources. Redundant elements also may hide their data from their competitors. ${ }^{145}$ But if sharing produces positive externalities, coordination and consolidation may produce better performance than competition (where no entity has an incentive to share). ${ }^{146}$ If elements do not compete against each other, but instead unite to achieve the same goal, they likely will cooperate more. ${ }^{147}$

Fifth, redundancy may increase decision-making and monitoring costs. ${ }^{148}$ With regard to decision making, "consumers" of intelligence will have more analyses to process and coordinate; decisions therefore may take

142. See supra notes 111-1 12 and accompanying text.

I43. In one manifestation, called "adverse reputational herding," "the initial agency will perform at the level of the redundant agency, and ... the entrance of the redundant agency fails to improve upon task performance compared to when such duplication did not occur." George A. Krause \& James W. Douglas, Are Two Heads Always Better than One? Redundancy, Competition, and Task Performance Quality in Public Bureaus 7 (Aug. 27, 2003) (unpublished manuscript on file with author); see also Abhijit Banerjee, A Simple Model of Herd Behavior, 107 Q.J. EcoN. 797 (1992). Krause and Douglas find that the OMB's tax revenue projections have become less accurate since the Congressional Budget Office, which produces similar projections, was established. Krause \& Douglas, supra, at 25.

144. See id.

145. Thomas H. Hammond et al., Intelligence Organizations and the Organization of Intelligence 41 (May 13, 2003) (unpublished manuscript on file with author); see also Garicano \& Posner, supra note 1 , at 163 (acknowledging that information exchange is easier when agencies are centralized).

146. See Edward T. Jennings, Jr. \& Jo Ann G. Ewalt, Interorganizational Coordination, Administrative Consolidation, and Policy Performance, 58 PUB. ADMIN. REv. 417, 425 (1998) (examining the delivery of job training services and concluding that coordination and, particularly, consolidation of organizations with overlapping missions yield better program outcomes).

147. See Gus C. Lee, The Organization for National Security, 9 Pub. Admin. Rev. 36, 43 (1949).

148. Betts, Analysis, War, and Decision, supra note 15, at 78; Whitford, supra note 118, at 160 , I64. But see Gary J. Miller \& Terry M. Moe, Bureaucrats, Legislators, and the Size of Government, 77 AM. PoL. SCI. Rev. 297, 310 (1983) (competition among agencies increases power of congressional monitor); William A. Niskanen, Bureaucrats and Politicians, 18 J. L. \& EcoN. 617, 637 (1975) (competition decreases cost of monitoring). 
longer to make. ${ }^{149}$ Consumers may have to make a tradeoff between quality of intelligence and speed of decision making. ${ }^{150} \mathrm{With}$ regard to monitoring, if agencies are competing for resources and are not producing easily comparable products, their overseers may have to devote far greater resources to monitoring and evaluating their effectiveness. Further, with redundant structures, it may be hard to affix blame or credit because it is hard to determine which entity is responsible for a particular success or failure. ${ }^{151}$

Sixth, redundancy may produce what engineers refer to as "Type I" and "Type II" errors. Type I errors result from the failure to stop an undesired event. Type II errors occur when there is a failure to produce a desired event. ${ }^{152}$ In the intelligence community a Type I error occurs when an agency fails to issue a needed warning and therefore fails to stop a tragic event (a false negative); a Type II error occurs when an agency issues an unneeded warning and therefore creates unnecessary action (a false positive). ${ }^{153}$ Serial structures, with each consecutive entity capable of issuing a given warning, can decrease Type I crrors. With serial structures in place, a Type I error occurs only if every unit fails to issue the needed warning. The more units, the more likely the proper warning will issue. However, since there are more agents to issue a false positive warning, Type II errors increase. ${ }^{154}$ Conversely, parallel structures, with any structure capable of stopping a warning from issuing, can decrease Type II errors because any entity can stop the issuance of a warning. ${ }^{155}$ Type I errors increase, however, because more entities can stop a warning that should issue.

In addition to the tradeoff between Type I and Type II errors, there also may be an interaction effect: a system designed to minimize Type I error may lead to an increase in Type II error, which may then lead to an increase in Type I error. ${ }^{156}$ Redundancy may also increase the probability of a "catastrophic common-mode error," i.e., a mistake that makes all

149. Williamson, supra note 116, at 123; Laffont \& Martimort, supra note 113, at 257. In the intelligence context, see Cynthia M. Grabo, Anticipating Surprise: Analysis for Strategic WARNING 144 (2002) (discussing advantages and disadvantages of unanimity for decision making).

150. Betts, Analysis, War, and Decision, supra note 15, at 78 .

151. BENDOR, supra note 122 , at 30 .

152. Id. at 50; see also Heimann, supra note 133, at 46; C.F. Larry Hcimann, Understanding the Challenger Disaster: Organizational Structure and the Design of Reliable Systems, 87 AM. PoL. ScI. REv. 421, 422 (1993). For example, for the National Aeronautics and Space Administration (NASA), if the proper policy is to abort a launch and NASA decides to launch, the agency has committed a Type 1 error (i.e., implementing the wrong policy); if the proper policy is to launch and NASA decides to abort, the agency has committed a Type II error (i.e., failing to implement the right policy). Id.

153. Hammond, supra note 16, at 39-40.

154. See Garicano \& Posner, supra note I, at 158 (noting that false positives "lull decisionmakers into ignoring future wamings that may be accurate").

155. Heimann, supra note 152, at 427.

156. Hammond, supra note 16 , at $40-41$. 
components fail. ${ }^{157}$ For example, each redundant airplane engine "both increases the likelihood that the redundant engine will keep the plane in the air if all others fail in flight and increases the probability that a single engine will cause an accident, by blowing up or starting a fire that destroys all the other engines and the aircraft itself."158

How these advantages and disadvantages of redundancy (and conversely, in most circumstances, of unification) apply to any particular area of government organization is complex. Each situation requires considerable investigation. To determine, in fact, whether redundant or unified structures are more effective, policymakers must analyze and compare their benefits and costs. ${ }^{159}$ This analysis generally must consider the following criteria: "[p]robability of error and of error detection"; "[c]ost of error"; "[e]ost of redundancy versus cost of monopoly"; "[i]nteraction between type one and type two errors"; and "[s]earch behavior and the possibility of significant innovation." 160 To be certain, these factors are tremendously difficult to calculate. Such calculations depend on assumptions concerning bureaucratic behavior. For example, do organizations act rationally and hence strategically? Alternatively, do they act randomly? ${ }^{161}$ Even if agencies and congressional committees "adapt to their surroundings in an imprecise way," 162 they presumably act to further particular goals, given any constraints. Then, of course, articulating those objectives and constraints becomes a challenging task.

Despite these difficulties, it is dangerous to think only about a particular issue - for example, the lack of information sharing or the costs of duplicate structures - and ignore how all of these factors interact. ${ }^{163}$ Before a branch of government undergoes major restructuring, decision makers

157. C.F. LaRry Heimann, ACCEPTABle RISKs supra note 122, at 10; Sagan, supra note 141, at 937. This potential failure of a complex and often redundant system is termed "normal accidents" theory. Scott D. Sagan, The Limits of Safety: Organizations, accidents, and Nuclear WEAPONS 44 (1993) (contrasting "normal accidents" theory and "high reliability" theory to explain effects of redundant structures).

158. Sagan, supra note 141 , at 937.

159. See Felsenthal, supra note 109, at 250 ("To evaluate the desired amount of backup redundancy, three considerations must be taken into account: (1) the probability of different types of system failure or overload occurring over a specified time period which a backup unit, if installed, can correct; (2) the cost of installing and maintaining the redundant backup components; and (3) the costs associated with different lengths of time elapsing until a failure can be corrected.").

160. BENDOR, supra note 122 , at $248-51$.

161. Some scholars contend that a "garbage can" theory best explains organizational behavior: "[The theory] holds that in some organizations ... the connections between problems and solutions, between decision makers and choices, and between intentions and outcomes are loosely coupled and, indeed, may vary in an almost random fashion.” LEE Clarke, ACCEPTABle RisK? Making Decisions in a Toxic Environment 26-27 (1989); see also Michael D. Cohen et al., $A$ Garbage Can Model of Organizational Choice, 17 Admin. Sci. Q. 1 (1972).

162. Whitford, supra note 118 , at 161.

163. Cf. Henry Petroski, Design Paradigms: Case Histories of Error and Judgment in ENGINEERING 115,119 (1994) (discussing the problem of tunnel vision in designing bridges). 
should explicitly consider whether unification or redundancy is more likely to achieve a particular goal, in this case, better national security. The next two Sections analyze these factors more carefully as applied first to the intelligence community and then to its congressional overseers.

\section{Organization of the Intelligence Community}

This Section considers some of the advantagcs and disadvantages of redundancy and unification for the intelligence community. lt assumes that agencies are strategic, that there are costs of delegating work to that community, and that Congress is motivated solely by maximizing effectiveness for enhancing national security, net of its financial costs. ${ }^{164}$ Depending on the circumstances, Congress should delegate to multiple, redundant agencies that are not unified (decentralized, redundant delegation), to only one agency (unified, nonredundant delegation), or to unified, multiple agencies (unified, less redundant delegation). These circumstances are determined by comparing the net benefits of all possible structural arrangements. The 9/11 Commission did not ask Congress to delegate intelligence work to fewer agencies, but rather proposed that the agencies tasked with intelligence functions report, in essence, to one boss, and that agencies use joint intelligence resources instead of relying entirely or predominantly on their own resources. When is such partial consolidation of agencies beneficial?

The Appendix describes a simple game theory model for thinking about these issues for the intelligence community and its congressional overseers. As the difference in cost between delegating to decentralized agencies and delegating to a unified intelligence community grows, all else being equal, the payoff to a unified intelligence community also grows. On the one hand, a unified structure likely eliminates some redundancy. The 9/11 Commission believed that the federal government "cannot afford so much duplication of effort" and that such duplication "places extra demands on already hard-pressed single-source national technical intelligence collectors like the [NSA]." ${ }^{\text {165 }}$ Specifically, the Commission called for the ClA's paramilitary functions to be placed under the Department of Defense, in order to eliminate the redundancy of both

I64. Sections II.B and II.C do not make the same assumptions.

165. 9/I I COMMISSION REPORT, supra note 3, at 401. The Commission posited that without unified authority over intelligence agencies, duplication (presumably unnecessary duplication) could not be eliminated: "Lines of operational authority run to the expanding executive departments, and they are guarded for understandable reasons: the DCI commands the ClA's personnel overseas; the [S]ecretary of [D]efense will not yield to others in conveying commands to military forces; the Justice Department will not give up the responsibility of deciding whether to seek arrest warrants. But the result is that each agency or department needs its own intelligence apparatus to support the performance of its duties. It is hard to 'break down stovepipes' when there are so many stoves that are legally and politically entitled to have cast-iron pipes of their own." Id. at 403 . 
agencies maintaining such capabilities. ${ }^{166}$ The WMD Commission seemed slightly less concerned about duplication costs. ${ }^{167}$ DNI Negroponte has indicated that "[i]n some instances, the overlap adds value," but that in other cases "it consumes resources more appropriately directed to the intelligence community member having the mission at its core, or to emerging national security threats." 168

On the other hand, unification imposes costs of its own, including those of coordination. ${ }^{169}$ In an already hierarchical system, adding a DNI, yet another government agent who monitors other government agents in the intelligence community, "lengthen[s] the time it takes for intelligence analyses to reach the president." 170

By contrast, as the difference in benefits from delegating to multiple agencies and delegating to a unified intelligence community grows, all else being equal, the payoff to a redundant, nonunified intelligence community also grows. For example, multiple agencies that do not report to the same boss may be more likely to foil a terrorist plot because the decentralized structure may promote innovation and competition. ${ }^{171}$ According to the Center for Strategic and International Studies, coordination "is likely to mean fewer opposing views, just when you want to encourage those rare souls who got Iraq right." 172 Moreover, as the 9/1 I Commission acknowledged, "[t]he struggle against Islamist terrorism is so important that any clear-cut centralization of authority to manage and be accountable for it may concentrate too much power in one place."173

166. Id. at 415 ("Whether the price is measured in either money or people, the United States cannot afford to build two separate capabilities for carrying out secret military operations, secretly operating standoff missiles, and secretly training foreign military or paramilitary forces.").

167. WMD REPORT, supra note 10, at 288, 292-94.

168. Office of the Director of National Intelligence, The National Intelligence Strategy of The United States of AMERICa 18 (Oct. 2005). OfFice of The Director of National Intelligence, Progress, supra note 70, at 5 (reporting "using [authority under the Intelligence Reform Act] to push the intelligence community to operate as an integrated enterprise and eliminate duplication").

169. See David L. Boren, The Winds of Change at the CIA, 101 YALE L.J. 853, 864 (1992).

170. Posner, supra note 1, at 11 ; see also Thomas, supra note 135, at 472 (noting that it is hard for one government agency to manage another).

171. See In defense of the intelligence services, Economist, July 31, 2004, at 21, 23.

172. Centralised intelligence? Intelligence Reform, EconomisT, Dec. 11, 2004, at 33. See also Betts, New Politics, supra note 15, at 6 ("[T] he message of dismay over mistaken estimates of Iraqi WMD is that analysis must be more careful and avoid jumping to conclusions-which implies more checks, balances, and deliberation, along with the personnel and organizational complexity that will naturally accompany them."). On the other hand, "[t]o the extent that multiple advocacy works, and succeeds in maximizing the number of views promulgated and in supporting the argumentative resources of all contending analysts, it may simply highlight ambiguity rather than resolve it." Betts, Analysis, War, and Decision, supra note 15, at 76. Furthermore, "in the context of data overload, uncertainty, and time constraints, multiple advocacy may in effect give all of the various viewpoints an aura of empirical respectability and allow a leader to choose whichever accords with his predisposition." Id. In other words, multiple viewpoints may not improve national security.

173. 9/I I COMMISSION RePORT, supra note 3, at 406. 
To the extent that the country faces multiple threats aside from terrorism, redundant structures may help diminish the possibility that the intelligence community will be unable to respond to a particular threat because each entity has invested its resources in other matters. Thus, redundant structures may make it more likely that at least one agency is up to speed on any given threat. ${ }^{174}$ Further, the events of September 11, 2001 themselves may have encouraged intelligence agencies to share information; ${ }^{175}$ thus, collaborative work may occur even without structural reform. ${ }^{176}$ Advocates of redundant, decentralized agencies essentially see decentralization of the intelligence community as promoting necessary competition among agencies. ${ }^{177}$

Despite these benefits of a decentralized system, a unified structure also has some advantages. A unified structure encourages agency collaboration, increasing the likelihood of a positive outcome. ${ }^{178} \mathrm{~A}$ coordinator of agencies, with real authority, could force needed cooperation. ${ }^{179}$ The $9 / 11$ Commission focused on this potential benefit: "The importance of integrated, all-source analysis cannot be overstated. Without it, it is not possible to 'connect the dots.' No one component holds all the relevant information." "180 Before the 1ntelligence Reform Act, intelligence agencies "ke[pt] much of the immediate results of their intelligence collection activities within their own institutional structure."181 The agencies shared

174. See George F. Treverton, Reshaping National Intelligence for an Age of INFORMATION 2 (2003); Felsenthal, supra note 109, at 251; Hammond, supra note 16, at 46; Posner, supra note 1 , at 11 .

175. 9/I I CoMmission RePORT, supra note 3, at 400; see also Posner, supra note 1 , at 11 ("Indeed, the [9/1 I Commission] [R]eport suggests no current impediments to the flow of information within and among intelligence ageneies concerning lslamist terrorism.").

176. Nevertheless, sharing of information is likely greater in a unified structure where such sharing can be encouraged, but also required. This Article focuses on the structure of organizations, but the structure of tasks (e.g., collection of information, analysis of information, etc.) could also be the primary unit of analysis. Would redundant information collectors be likely to horde information and to refuse to turn it over to a centralized database for storage?

177. BeRKowITz \& GoODMAN, supra note 113, at 122 ("A flexible, decentralized intelligence community managed through market-like mechanisms is better suited to the new environment."); Sherman Kent, Strategic Intelligence for American World Policy 76 (1996) ("Intelligence organizations are in competition with each other. They must study the market and develop its unexploited interstices.").

178. See Philip Shenon, Rumsfeld Wary About Shuffling Spy Duties, N.Y. TImES, Aug. 18, 2004, at A10 (noting that Secretary of Defense Rumsfeld conceded that the creation of a National Intelligence Director position "could conceivably lead to some efficieneies in some aspects of intelligence collection") (internal quotation marks omitted). This argument does not assume that ageneies intentionally will not share information without unified authority. Rather, the argument assumes that agencies acting in good faith still may fail to share necessary information, perhaps because they do not realize the value of particular information. See 9/1I COMmission REPORT, supra note 3, at 267 (describing gap in the sharing of information even "when there is mutual goodwill").

179. See Intelligence Shuffle, WASH. Post, July 4, 2005, at A16.

180. 9/1 1 COMMISsION REPORT, supra note 3, at 408.

181. Ronald D. Lee \& Paul M. Schwartz, Beyond the "War" on Terrorism: Towards the New Intelligence Network, 103 MiCH. L. Rev. 1446, 1473 (2005). 
reports but did not share "the raw intelligence underlying factual assertions and analytic conclusions set forth in their reports with outside agencies."182 In its call for organizational change, the 9/11 Commission singled out for criticism this norm of protecting information. ${ }^{183}$ The WMD Commission agreed, concluding that inadequate sharing of information contributed to the intelligence failure concerning WMDs in Iraq. ${ }^{184}$ Moreover, even if unification produces "more imperfect decisions than a more decentralized and competitive process," the difference may be "more than offset by improvements in operational coherence." 185

To reiterate, a unified agency structure does not necessarily mean there is no redundancy, though a unified structure of multiple agencies generally contains less redundancy than a nonunified structure of those same agencies. For example, the WMD Commission recommended that the DNI be given funds to sponsor research into new technology that "might be neglected by individual collection agencies." 186 Without a central coordinator, however, redundant structures may interfere with each other's efforts. For example, CIA paramilitary and Defense Department Special Forces units engaging in similar covert operations in the same small village in Afghanistan could produce a worse outcome than either operating alone. ${ }^{187}$

In addition to the costs and benefits of redundancy, where the agency is in the Executive Branch may provide an additional dimension for analysis. An independent agency that does not fall under the direct control of the President may be more or less effective at protecting national security than an executive agency. Thus, agency independence may substitute for the benefits or costs of agency redundancy. In the intelligence community, the CIA is arguably the most independent member, as a free-standing agency within the Executive Office of the President, though it is not as independent as an independent regulatory commission can be, ${ }^{188}$ the other agencies

182. Id. Agencies did not release the "raw intelligence" due to "concerns that releasing this information would compromise intelligence sources and methods; the difficulties of constructing secure means of access and distribution for data that are held in many different forms in many different locations; and perhaps an almost proprietary feeling that other agencies would not have the appropriate expertise to interpret the raw intelligence and should reply upon the originating agency's reports and interpretations." Id. at 1446. Bureaucratic rivalry also played a part, with "each [agency] concerned that another agency's access to its investigative materials or raw intelligence might enable the second agency to use that information and thereby either get the credit for producing a vital intelligence insight or inadvertently interfere with an ongoing intelligence operation being conducted by the agency that originated the information." Id. at 1474. See also TREVERTON, supra note 174, at 215.

183. 9/1 I COMMISSION REPORT, supra note 3, at 417.

184. WMD REPORT, supra note 10, at 14.

185. Eugene Bardach, How Do They Stack Up? The 9/II Commission Report and the Management Literature, 8 INT'L PUB. MGMT J. 351, 357 (2005).

186. Id. at 326.

187. There is some concern this is happening, though officials deny it. See BEST, supra note 21, at 16; cf. Karen DeYoung, A Fight Against Terrorism-and Disorganization, WASH. Post, Aug. 9, 2006, at Al.

188. See Richelson, supra note 17 , at 17 . 
such as the NSA and DIA are traditional executive agencies that sit within a cabinet department. The DNI also is not independent of the President. ${ }^{189}$ Thus, when considering the net benefits of a decentralized intelligence community and the net benefits of a unified community under the DNI, agency type does not seem to play a role. But agency type could play an important role in other possible reorganizations of the intelligence community-for example, if the DNI were modeled after the Federal Reserve Chairman. ${ }^{190}$

This Section has shown that simple rules of thumb - always delegate the same task to multiple agencies, never delegate the same task to multiple agencies, always place related agencies under the same boss, never unify competing agencies-ignore important lessons from theoretical and empirical research on bureaucratic organization. To maximize national security effectiveness, the $9 / 11$ Commission's proposal to unify intelligence agencies should only have been adopted if the net benefits of having unified bureaucracies with decreased redundancy were greater than the net benefits of decentralized, redundant delegation. Whether that condition holds in reality here or in any other policy area requires further empirical investigation. ${ }^{191}$

That empirical investigation should answer at least the following questions:

(1) Do multiple, decentralized intelligence agencies free-ride off each other's efforts? Or do they provide additional reliability?

(2) What are the costs of having multiple, decentralized intelligence agencies? What, if any, negative externalities are produced by decentralized, redundant organizations? What are the costs of having centralized, less redundant intelligence agencies? What, if any, negative externalities are produced in a unified system?

(3) What are the benefits of having multiple, decentralized intelligence agencies? Do such agencies produce positive externalities? What are the benefits of having centralized, less redundant intelligence agencies? Does unification produce positive externalities?

As noted previously, the 9/11 Commission's proposals seem to emphasize the costs of decentralization and the benefits of unification, but those two factors will not necessarily maximize national security effectiveness.

189. Cf. Review of the $9 / 11$ Commission's Intelligence Recommendations: Hearings Before the Senate Committee on Appropriations, 108th Cong. 48 (2004) (statement of Dr. John J. Hamre, President and CEO of the Center of Strategic and Interpational Studies) (noting that there are risks, in terms of national security effectiveness, with having the' DNI report directly to the White House).

190. See Paul R. Pillar, Intelligence, Policy, and the War in Iraq, Foreign AfF., Mar./Apr. 2006 at $15,27$.

191. Cf. Thomas, supra note 135, at 458 (noting paucity of work evaluating bureaucratic reorganization). 
Policymakers must also consider the benefits of decentralized agencies and the costs of unification. By weighing the net benefits of decentralization, unification, and various combinations of the two poles, policymakers can make decisions that truly maximize national security effectiveness. ${ }^{192}$

The ideal structure of the intelligence community, considering only national security, likely is neither completely decentralized, with some redundancy, nor entirely centralized, with no redundancy. ${ }^{193}$ Rather, the most effective structure probably would have redundant components as well as components that coordinate and centralize certain efforts. ${ }^{194}$ For example, certain intelligence functions, such as establishing targets for information gathering or processing and analyzing information, could be redundant but coordinated in some way, while other functions such as information collection, were centralized with little redundancy. ${ }^{195}$ Analysis of collected information seems the most competitive of the community's tasks and prone to group-think. ${ }^{196}$ Risk of interference is low. The cost of additional

192. Measuring these benefits and costs may be difficult, and some may be impossible to assess. See, e.g., Sidney A. Shapiro \& Robert Glicksman, Risk Regulation at Risk: Restoring a Pragmatic Approach (2003); Frank Ackerman et al., Applying Cost-Benefit to Past Decisions: Was Environmental Protection Ever a Good Idea?, 57 ADMiN. L. REV. 155 (2005). The 9/11 Commission may well be right that its proposed changcs will yield net benefits for national security, but other reforms may yield greater net gains. Cf. Betts, Analysis, War, and Decision, supra note 15, at 86 ("Few of the changes in structure and process [of the intelligence community] have generated more costs than benefits. . . But it is difficult to prove that they have significantly reduced the incidence of intelligence failure."). For an example of a similar framework (costs and benefits to specialization and coordination in tax and spending programs), see Weisbach \& Nussim, supra note 14.

193. See TREVERTON, supra note 174, at 15, 242-43 (calling for decentralization in the intelligence community but some coordination of agencies); Lee \& Schwartz, supra note 181, at 1477 ("The hope is that, in the best of all possible intelligence worlds, this model [for building intelligence networks for data] will permit both decentralized and centralized analysis."); $c f$. Jody Freeman \& Daniel A. Farber, Modular Environmental Regulation, 54 DUKE L.J. 795, 891-94 (2005) (advancing normative framework for coordinating a variety of regulatory decisions and tools in environmental law and natural resource management).

194. The military is an example of such a structure. It has four individual services, with some overlapping and some nonredundant capabilities, and the Joint Chiefs of Staff, who perform certain coordinating functions for the Secretary of Defense and the President. Whether this structure is the most effective for the military is an open question. Its formation in 1947 and its subsequent major reform in 1986, which, inter alia, strengthened the JCS Chairman, was contested. See, e.g., АMY B, Zegart, Flawed by Design: The Evolution of the CIA, JCS, and NSC 11, 140 (1999); Elias Huzar, Notes on the Unification Controversy, 4 Pub. Admin. Rev. 297, 300-01 (1946). The 9/11 Commission did point to the military's unified joint commands when calling for the establishment of the NCTC. 9/I I COMMission REPORT, supra note 3, at 403.

195. This proposal has analogies in other areas. The semiconductor industry established a unified generic research and development program due to its high costs but then competitive firms try to apply that information for commercial profit. Semiconductor Research Corporation, SRC: The Early Years, available at http://www.src.org/member/about/history.asp; cf. Thomas A. Piraino, Jr., Reconciling Competition and Cooperation: A New Antitrust Standard for Joint Ventures, 35 WM. \& MARY L. REv. 871, 912-13 (1994).

196. Cf. Michael Herman, Intelligence Power in Peace and War 227-28 (1996) (noting worry about group think); RiCHELSON, supra note 17, at 315, 455 (listing agencies that analyze information and remarking on danger of centralization in this area). 
analysts presumably is lower than the cost of duplicate satellite technology, though redundancy in analysis does produce higher decision-making costs for the policy maker who must wade through more material. By contrast, redundancy in information collection has, in certain areas, more risk of interference and high costs. ${ }^{197}$ There may even be increasing returns to scale for some collection. Cooperation in the gathering and sharing of information also is critical for national security. Such a mixed organizational structure could also emphasize selection of targets for information collection and analysis over the actual collection of particular types of intelligence. ${ }^{198}$

One assumption and one caveat deserve mention. This Article assumes, based on considerable research in the social sciences, that organizational structure can have significant effects and is indeed likely to have considerable effects (relative to other factors) on how agencies perform tasks delegated to them and hence on national security. ${ }^{199}$ In other words, organizational ehange is often necessary, although rarely sufficient, for operational change, and therefore for changes in national security. ${ }^{200}$ "[O]rganizational routines and cultures" also matter, ${ }^{201}$ as do policymakers' use of intelligence products. ${ }^{202}$

197. See John Hamre, A Better Way to Improve Intelligence: The National Director Should Oversee Only the Agencies that Gather Data, WASH. Post, Aug. 9, 2004, at A15.

198. See TREVERTON, supra note 174, at 227 (calling for the emphasis in intelligence to shift from collection to processing and analysis); cf. Herman, supra note 196, at 39 (most intelligence work involves information collection). By some accounts, intelligence ageneies analyze only five percent of the data collected. Tim Weiner, Langley, We Have a Problem, N.Y. Times, May 14, 2006, at 1, 3 (Week in Review).

199. HeimanN, supra note 122, at 176; cf. Hult, supra note 14 , at $184-85$ (examining the factors for operational suceess of agency mergers, including "background factors," "characteristics of merger decision," "implementation characteristics" and "agency permeability").

200. 9/I I COMmission RePORT, supra note 3, at 399; Hammond, supra note 16, at 49; Hammond et al., supra note 145, at 11-12; cf. Betts, New Politics, supra note 15, at 6 ("In the 1960s, for example, the Secretary of Defense tried to rationalize and consolidate military intelligence by transferring duplicative activities of the Army, Navy, and Air Force intelligence agencies to the newly created Defense Intelligence Agency. But the result was more redundancy rather than less, since the services soon regenerated most of what they had lost."); but see POSNER, supra note 1, at 157 ("The startling implication ... is that the performance of a nation's intelligence system is probably, within a broad range, insensitive to how it is organized."); Christopher Brady, Intelligence Failures: Plus Ca Change ..., 8 INTElLIGENCE \& NAT'L SeCURITY 86, 87 (Oct. 1993) ("Nevertheless, as important as structural or organizational factors might be, they can only be seen as second-order explanations when compared with the psychological and cultural barriers which are at the very core of the decision-making process."); John Deutch, Exiting Iraq, HarVARD MAG., Sept./Oct. 2005, at 32, 33 ("No one should imagine that the deficiencies in intelligence responsible for these two failures $[9 / 11$ and estimate of WMDs in Iraq] could be remedied entirely, or even primarily, by reorganization.").

201. Zegart, supra note 14 , at 110 ; see also James Q. Wilson, Bureaucracy: What Government Agencies Do and Why They Do It 267-68 (I989) (arguing that reorganizations that shift boxes on an organization chart but do not redefine agencies' functions may result in little change); Bibas, supra note 116 , at $39-40$ (summarizing management and organizational literature on the importance of office cultures and personnel).

202. Betts, Analysis, War, and Decision, supra note 15, at 71-72 ("Disasters always stimulate organizational changc designed to avert the same failures in the future... In many instances, however, the changes persist formally but erode substantively .... Organizational innovations will not 
The caveat is that the investigation this Article outlines does not explicitly analyze the costs of reorganizing institutions, but the framework could easily incorporate such costs. Commissions and policymakers are not creating an intelligence community from scratch; they are trying to reorganize a bureaucracy that already exists. Shifting structures creates transition costs, both anticipated and unforeseen, that may affect reform choices. ${ }^{203}$ For example, if unification has only slightly higher net benefits than the system in place prior to September 11,2001 , then the costs of reforming the system under the 1ntelligence Reform Act likely outweigh the benefits. $^{204}$

\section{Organization of Congressional Oversight}

This Section considers the advantages and disadvantages of redundancy as well as unification of congressional oversight of the intelligence community. Some congressional oversight is warranted to maximize national security effectiveness, both to encourage intelligence agencies to work diligently, rather than to free-ride off efforts of others, and to improve the quality of agency work. But more oversight is not necessarily better than less, if the one concern is the quality of intelligence outcomes and the enhancement of national security. Furthermore, unified oversight may not be better than fragmented or overlapping oversight. To the extent that the structure of oversight is tied to the amount or quality of oversight, reform efforts should target oversight structure. This Section examines how redundancy (or unification) in oversight can help or hinder agencies tasked with obtaining critical information, and how it can motivate them to work most energetically and effectively. ${ }^{205}$

Consider first how redundancy in oversight could produce benefits for enhancing national security. To begin, much like bureaucratic redundancy, oversight redundancy may yield a higher chance of success in achieving a particular goal because different committees may have different expertise or "approach questions from entirely different viewpoints." 206 For example, the House Armed Services Committee might have a critical insight that the

improve the role of intelligence in policy unless they flow from the decision makers' views of their own needs and unless they provide frequent practical benefits.").

203. See William J. Lynn \& Barry R. Posen, The Case for JCS Reform, 10 INT'L SEC. 69, 96 (1985) ("[T]o reduce the opportunities for unintended consequences, organizational reforms should follow the least disruptive route.").

204. See Garicano \& Posner, supra note 1, at 167. This outcome depends on how costs and benefits are diseounted.

205. For congressional organization, unification almost always implies lack of redundancy. One could build in redundancy into a particular committee by giving the ranking minority member the same powers as the chairman.

206. Walter J. Oleszek, Integration and Fragmentation: Key Themes of Congressional Change, 466 Annals of The AM. ACAD. Pol. \& Soc. SCI. 193, 196 (1983) (internal quotation marks omitted); see also Staudt, supra note 14, at 1220. 
House Homeland Security Committee does not. ${ }^{207}$ On the other hand, the model in the Appendix shows that where redundancy in delegation exists, "beneficial oversight," that is, oversight that increases the chance of a nonfree-riding agency succeeding at its task, may make it more likely that redundant agencies will free-ride. This occurs because agencies recognize that their redundant action is less likely to make a difference. ${ }^{208}$ This result derives from the assumption that redundant agencies are strategic actors and make decisions about what to do by considering what other agencies are likely to do. Where more ovcrsight leads to more agencies free-riding, the net effect of more oversight may be that the intelligence community is less effective at promoting national security.

Redundancy also may reduce the chances of congressional overseers being "captured" by the agencies they ovcrsee-that is, developing cozy relationships of mutual interest or comfort. Without redundancy in oversight, one committee with exclusive jurisdiction may develop an overly "close and supportive relationship with the executive entities it oversees, rather than a neutral and critical one."209 In other words, redundant congressional committees may improve national security by making oversight less conducive to capture by interests that care about objectives other than national security. ${ }^{210}$ This may be especially important during periods of united government, when the same party controls the White House and both chambers of Congress. ${ }^{211}$ In addition, if more members of Congress sit on committees with authority to oversee the intelligence community, it is more likely that the overseers, on average, better represent the interests of all members of Congress. ${ }^{212}$ Having multiple oversight committees will not provide these benefits, however, if each committee oversees a clearly distinct portion of the intelligence community (for example, particular

207. KAISER, supra note 15 , at 11 . The committees do not need to be simultaneously active. The redundancy could be dormant: one committee could do nothing unless the other committee ignores its oversight duties.

208. Also, the complexity of the intelligence community's work makes oversight costly. DENIS McDonough et al., Center for american Progress, No Mere Oversight: Congressional OVERSIGHT OF INTELLIGENCE IS BROKEN 27 (June 2006) (“[1]t is extremely difficult for already busy committee members to master the intricacies of l the intelligence community'sl programs ....")

209. KaISER, supra note 15, at 10; see also Loch K. Johnson, America's Secret Power: The CIA IN A Democratic Society 222 (1989); Ransom, supra note 24, at 159-60; Treverton, supra note 33 , at 102 .

210. See David C. King, Turf Wars: How Congressional Committees Claim Jurisdiction 144 (1997); cf. Ott, supra note 92, at 79.

211. Unified government often prevents effective oversight of the Executive Branch. See Daryl Levinson \& Richard H. Pildes, Separation of Parties, Not Powers, 119 HARv. L. Rev. 2311 (2006); Dana Milbank, Bush's Fumbles Spur New Talk of Oversight on Hill, WASH. PosT, Dec. 18, 2005, at A7.

212. KING, supra note 210 , at 139. If overseers are "outlier" members, oversight may not be "efficient" or, more likely, may not be perceived as democratically legitimate. See J.R. DeShazo \& Jody Freeman, The Congressional Competition to Control Delegated Power, 81 TEx. L. REv. 1443, 1445 (2003). 
agencies or intelligence tasks). Such specialization could deepen committee members' knowledge of their particular area and their connections with relevant interest groups. ${ }^{213}$ Such specialization could also increase the likelihood of capture. ${ }^{214}$

Redundancy in the committee system may, moreover, increase the number of members of Congress with knowledge about the intelligence community. ${ }^{215}$ To the extent that particular committee members drive oversight, organizational redundancy may mitigate the effects of those members' retirement, electoral defeat, or diminishing energy. ${ }^{216}$ Finally, redundancy may "foste[r] communication and consensus within the legislature prior to the time an initiative reaches the floor, making it easier to pass worthwhile legislation." "217 If more committees consider and approve an initiative, those committee members who favored the initiative are likely to support the bill when it comes up for a vote on the floor.

Redundancy in oversight also has potential costs. Multiple committees with the same jurisdiction typically consume more resources than one larger committee with exclusive jurisdiction. ${ }^{218}$ These committees may fail to provide oversight, instead focusing on other topics in their exclusive jurisdiction, free-riding off the efforts of others, and facing little accountability for shirking. ${ }^{219}$ Members of Congress "have multiple committee assignments and, under the best of circumstances, have difficulty giving adequate time and attention to any one of them." 220 Often only a few committee members attend hearings in their entirety. ${ }^{221}$ Alternatively, multiple committees may engage in too much oversight. For example, if officials are constantly testifying to congressional committees, producing written reports for them, or responding to their requests for information, those officials may have insufficient time to actually run their agencies. ${ }^{222}$

213. Cf. Huzar, supra note 194, at 312.

214. See infra text accompanying note 223.

215. KAISER, supra note 15 , at 14 .

216. Cf. Loch Johnson, The U.S. Congress and the CIA: Monitoring the Dark Side of Government, 4 LEG. STUD. Q. 477, 481, 492 (1980) (stressing importance of individual members).

217. Staudt, supra note 14, at 1219-20; see also KING, supra note 210, at 144.

218. See KING, supra note 210, at 9; KAISER, supra note 15 , at 10.

219. Because the political benefits to some amount of oversight likely outweigh its costs, congressional committees probably will not shirk their oversight duties completely. Committees, however, may focus on activities that are more conducive to media coverage than to improvement of agency outcomes. 9/1 I COMMISSION REPORT, supra note 3, at 106.

220. Ott, supra note 92, at 87; see also Frank J. SMIST, JR., Congress Oversees the UnIted STATES INTELLIGENCE COMMUNiTy, 1947-1989, at 223 (1990).

221. See JoHnson, supra note 24 , at 97 (noting that a majority of members on the lntelligence Committecs attended only $35 \%$ of public hearings from 1975 to 1990 and that Senators, despite more committee assignments, had better attendance records than Representatives).

222. Cf. SMIST, supra note 220 , at 13 ("[C]ongressional overseers in the intelligence area must walk a fine line to avoid conducting oversight that will either irreparably damage a vital governmental function or be so weak that it is meaningless."); Treverton, supra note 33, at 104 ("Like other committees, [the Intelligence Committees] have also been tempted to 'micromanage'; the line between 
In addition, redundancy may foster specialization and intimate relationships that undermine national security effectiveness if "[s]weetheart alliances" arise between committees, the agencies administering their programs, and various interest groups. ${ }^{223}$ With multiple committees, the public may devote less attention to any particular one, allowing interest groups to co-opt particular committee agendas. If that occurs, intelligence agcncies may politicize their analyses, telling certain overseers what they want to hear. ${ }^{224}$

Even without the influence of interest groups, committees may protect the agencies they oversee once they have formed close relationships with those agencies. In the absence of "concrete allegations of fraud or mismanagement," committees may be less likely to thoroughly evaluate and reassess agency programs. ${ }^{225}$ With relatively few interest groups following the intelligence community and with the issues often technical or veiled by secrecy, intelligence-related committees will rarely face headline-grabbing calls by interest groups for congressional action. ${ }^{226}$

Similar to bureaucratic redundancy, oversight redundancy also may prevent cooperation and sharing of expertise that is needed for national security. ${ }^{227}$ This occurs because the committee structure impedes coordinated policies. ${ }^{228}$ Further, if Congress needs to develop specialization, it can do so within a committee, through subcommittees, rather than establishing multiple committees. ${ }^{229}$ Finally, in a policy area dependent on secrecy, redundancy increases the risk of inadvertent or intentional disclosure of classified information. ${ }^{230}$

A single joint House-Senate committee with exclusive jurisdiction over the intelligence community, in particular, has certain benefits and

oversight and management can blur, especially perhaps if the subject to be managed is exciting."); Eric Lichtblau, Complaints Signal Tension Between F.B.I. and Congress, N.Y. TImES, Aug. 15, 2005, at A13 ("Some officials say they have felt besieged by demands from Congress for information that is voluminous and at times highly sensitive.").

223. DAVIDSON \& OlesZEK, supra note 27, at 342.

224. TREVERTON, supra note 174 , at 198.

225. DAVIDSON \& OLESZEK, supra note 27, at 342.

226. Loch K. Johnson, Congressional Supervision of America's Secret Agencies: The Experience and Legacy of the Church Committee, in STRATEgic InTElligence: Windows INTO A SECRET World 414, 415 (Loch K. Johnson \& James J. Wirtz eds., 2004); cf. Mathew McCubbins and Thomas Schwartz, Congressional Oversight Overlooked: Police Patrols versus Fire Alarms, 28 AM. J. PoL. ScI. 165 (1984).

227. Cf. Treverton, supra note 33, at 107 (noting problem of miscommunication).

228. Oleszek, supra note 206, at 196 (internal quotation marks omitted); see also KING, supra note 210 , at 139 .

229. Cf. Huzar, supra note 194 , at 312 . House committees generally cannot create more than five subcommittees (six if one is an oversight subcommittee). House Rule X, cl. 5(d).

230. KAISER, supra note 15 , at 10 . In light of this concern, covert operations currently are diselosed to only two committees. Id. at 11. But see Ott, supra note 92, at 78 (arguing that the sources of most "leaks" in the 1980s were "predominantly, if not overwhelmingly, in the Executive Branchincluding the Intelligence Community itself, not the oversight committees"). 
costs. The Congressional Research Service has identified four main justifications for such a committee. First, the Executive Branch "would be more open and forthright with a single, small oversight body than with two with a larger combined membership." ${ }^{231}$ Second, "the legislators and staff on [a joint intelligence committee], recognizing that there is no other authorizing panel to conduct oversight, would attach a greater importance to this responsibility." 32 Third, "a committee composed of legislators from both chambers could better integrate and take advantage of congressional expertise and experience in the field." Finally, a joint committee "could be established with fewer restraints and restrictions than the separate select committees now have. ${ }^{.233}$ On the other hand, a joint committee may not have as much credibility in each chamber as the chamber's own committees, and may be especially prone to "cheerleading at best, sycophancy at worst.",234

The 9/11 Commission concluded that the system of redundant oversight failed because it neglected to perform sufficient oversight. ${ }^{235}$ In supporting its conclusion, the Commission found that congressional committees had conducted approximately three dozen hearings concerning terrorism from January I998 to September 2001, a low number in the Commission's view. ${ }^{236}$ By proposing the unification of congressional oversight, the 9/11 Commission appears to have believed that more hearings (and thus better oversight, in its view) would have taken place during that same period if there were only one committee in each chamber, or one joint committee across both chambers. ${ }^{237}$ To justify this counterfactual assumption, the Commission argued that a select group of members of Congress would master the subject and those members would oversee the intelligence establishment, and thus would be accountable for their work. ${ }^{238}$ The Commission's logic implies that it felt the committees did not produce sufficient oversight because their members lacked expertise and were not held accountable for their lack of oversight.

\footnotetext{
231. KAISER, supra note 15 , at 9.

232. Id.

233. Id.

234. SMIST, supra note 220 , at 277 ; Treverton, supra note 33 , at 107 .

235. 9/1 I COMMISSION REPORT, supra note 3, at 104-07. Ott agrees that since 1990, congressional oversight of the intelligence community has not been effective, but he eontends that oversight was effective during the 1980 s. Ott, supra note 92 , at $80-81$.

236. 9/I I COMMISSION REPORT, supra note 3, at 106-07; see also JoHNSON, supra note 24, at 96, 114 (noting that Intelligenee Committees held, on average, only 1.6 public hearings per year from 1975 to 1990 but that congressional oversight had increased during that time period).

237. Posner is not convinced that the 9/11 Commission's recommendation to reduce redundancy in congressional oversight came from a desire to "improve oversight." Rather, Posner suggests that a reduction in committees would "make it easier for the intelligence 'czar' recommended by the commission to control the intelligence system ...." POSNER, supra note 1, at 36 .

238. 9/I I COMMISsION REPORT, supra note 3, at 420.
} 
After September 11, 2001, even with no substantial changes in structure, some contend that congressional committees may have shifted from providing too little oversight to providing too much. Under this view, agency officials may be called to testify so frequently in front of congressional committees that the work of the agency suffers. ${ }^{239}$ Others, including the Center for American Progress, argue that congressional committees still do not perform sufficient oversight. ${ }^{240}$ The Agendas Project Hearings Dataset provides information on the number of national security related hearings before and after September 11, 2001. ${ }^{241}$ Figure 2 breaks down the two major relevant categories of hearings for the House and Senate. Hearings concerning terrorism and hijacking jumped between 1999-2000 and 2001-2002; hearings concerning intelligence dropped. Overall, these data show that national security hearings increased, ${ }^{242}$ but do not tell us the optimal amount of oversight for national security. ${ }^{243}$

Figure 2

\section{Military Intelligence, CIA, Espionage} House of

\begin{tabular}{|c|c|c|c|c|}
\hline & Representatives & Senate & Representatives & Senate \\
\hline $1999-2000$ & 8 & 14 & 10 & 7 \\
\hline $200 \mathrm{I}-2002$ & 7 & 4 & 48 & 34 \\
\hline
\end{tabular}

\section{Terrorism, Hijacking}

House of
Hearings are, of course, just one method of oversight. Committee members can also make inquires and requests for information via telephone calls, email messages, letters, and informal meetings. They can require more formal written reports at periodic intervals. They can undertake major investigations themselves, or ask the Government Accountability Office (GAO) to investigate. Finally, committees can limit agencies' activities by restricting appropriations, often an extreme form of oversight. ${ }^{244}$

239. KAISER, supra note 15 , at 10; Posner, supra note 1 , at 11. Fragmentation of oversight of the DHS "preserves the rivalries and cultural barriers that the creation of the Department was intended to eliminate; and it prevents DHS from acting as a single, well-coordinated team." CSIS-BENS TASK ForCE, supra note 95, at 2. Apparently, all Senators and over 400 Representatives exercise "some degree of oversight over DHS." Id.

240. MCDonOugh ET AL., supra note 208, at 7, 30 .

241. This dataset is maintained by the Policy Agendas Project run by Washington University and Pennsylvania State University, available at www.policyagendas.org.

242. Figure 2 reports the total number of hearings for issue eodes 1603 (Military 1ntelligence, C1A, Espionage) and 1927 (Terrorism, Hijacking) by each chamber of Congress for 1999-2000 and 2001-2002.

243. Mark M. Lowenthal, Intelligence: From Secrets to Policy 142 (2000) ('There is no objective way to determine the 'proper' level of oversight.").

244. See DAvidson \& OLESZEK, supra note 27, at 339; LowenthAL, supra note 243, at 136-41. 
Congressional oversight can occur ex ante (for example, through appropriations or structural or procedural controls governing agency action) or ex post (for example, through hearings or investigations). Redundant committees may affect the use of each oversight tool differently: for example, such a structure may produce free-riding on hearings because members do not want to invest time in listening to testimony but force agencies to complete more required reports for Congress because such reports may be more attractive for members. ${ }^{245}$

Oversight is also not limited to members of Congress. For example, within the Executive Branch, the OMB, Inspectors General, and the President's Foreign Intelligence Advisory Board can oversee intelligence agencies. ${ }^{246}$ Within the Legislative Branch, as mentioned previously, the GAO engages in oversight activities. ${ }^{247}$ The administration can establish special independent commissions "when the task is too much or too prolonged for more familiar committee hearings and when it requires unusual assurance of nonpartisanship." ${ }^{248}$ Such commissions can exist for short periods, like the 9/1 I Commission and WMD Commission, or for longer periods, with regular congressional review. ${ }^{249}$ Finally, interest groups and others can oversee intelligence agencies by attempting to sue them in the courts. ${ }^{250}$

245. Cf. KING, supra note 210 , at 142 (noting overlapping committee report requirements).

246. Lowenthal, supra note 243, at 134; HeymanN \& KAYyem, supra note 100, at 125-28. The lnspectors General have varying authority in the intelligence community. The ClA and all the cabinet departments have an IG appointed by the President and confirmed by the Senate with considerable authority; the NRO, DIA, NSA, NGIA, and DNI have administrative Inspectors General, selected by the agency head, who have less power. Report of Senate Select Committee on Intelligence to Accompany 3237, at $\S \S 408,433$.

247. The GAO has complained that the intelligence community rarely cooperates with its investigations. See Government accountability Office, DoD Personnel Clearances: Questions and answers for the Record Following the Second in a Series of Hearings on Fixing the Security Clearance Process, GAO-06-693R, at 1 n.l (June 14, 2006) ("While we have the authority to [oversee the intelligence community], we lack the cooperation we need to get out job done in that area. As a result, unless and until we receive such cooperation, and given GAO's limited recourse, we will continue our long-standing policy of not doing work that relates directly to intelligence matters unless requested to do so by one of the select intelligence committees."); KaISER, supra note 15 , at 14 n.20 (The GAO "is limited in its independent authority to audit and investigate the CIA, which apparently is off-limits to the [GAO] because of provisions in public law and congressional rules."); see also Frederick M. Kaiser, GAO Versus the CIA: Uphill Battles Against an Overpowering Force, 15 InT'L J. INTELLIGENCE \& CounterintelligenCE 330, 331, 337, 341, 350 (2002) (the CIA generally wins disputes with the GAO). Congress could write legislation requiring the $\mathrm{CIA}$ and other intelligence agencies to respond to GAO's requests for information but has not done so. Id. at $332,342,362,373$.

248. HEYMANN \& KAYYEM, supra note 100 , at 119.

249. See id. at 120-21.

250. Such plaintiffs, if contesting effectiveness of agency actions, would, however, be hard pressed to show standing. See, e.g., Lujan v. Defenders of Wildlife, 504 U.S. 555 (1992) (rejecting standing where the alleged injury was not sufficiently concrete or particularized). Moreover, the Administrative Procedure Act generally excludes review of military actions and exempts foreign affairs related rulemaking from notice and comment requirements. 5 U.S.C. $\$ \S 551$ (1)(G), 553 (a)(1) (2006). 
Congressional oversight, though, is still immensely important. Like the previous Section, this analytical framework presumes that structure influences, to some degree, oversight operations and therefore national security. Composition of committees or of committee staff may, however, be more important than the number of committees for national security effectiveness. ${ }^{251}$ Studies on group polarization suggest that congressional oversight would be more effective if committees were evenly balanced in terms of party membership and if the committee staff were nonpartisan. ${ }^{252} \mathrm{Stag}$ gering the terms of committee members may best balance the need for expertise and the need to incorporate different perspectives. The level of secrecy imposed on committees also may be more critical than the number of committees. According to the 9/11 Commission, "[s]ecrecy stifles oversight, accountability, and information sharing. ${ }^{253}$ If committee work concerning intelligence were more transparent to the public, members might be more accountable. ${ }^{254}$ This analysis also presumes that congressional committees, if they so choose, can obtain sufficient information from particular intelligence agencies to engage in at least some oversight. ${ }^{255}$ After September 11, 2001, however, committees complained that they were not receiving all of the information they believed they needed from particular agencies. ${ }^{256}$

The 9/11 Commission's proposal to restructure congressional oversight, like its proposal on intelligence agencies, should be analyzed by comparing the net benefits to unified oversight with the net benefits of decentralized, overlapping oversight. This Section has suggested various

Finally, the govcrnment can try to dismiss cases on the state secrets privilege. See, e.g., United States v. Reynolds, 345 U.S. 1 (1953).

251. See JohNSON, supra note 209, at 211 ("The motivations of members are more central to oversight efforts than are structural factors.").

252. Sunstein, supra note 111, at 103-04 ("If Republicans are speaking mostly with Republicans, and if Democrats are speaking mostly with Democrats, one should expect a hardening of views toward the more extreme points."). Committees typically have partisan staffs, i.e., each party or committee member chooses its own staff, but may have nonpartisan staffs. See House Rule X, cl. 9; Senate Rule XXVIl; KAISER, supra note 15, at 7-8. Senate Resolution 445 formally distributed the Senate Intelligence Committee's staff at a $3: 2$ ratio between the two parties, not including staff members appointed by individual Senators. RUNDQUIST \& DAvIS, supra note 92, at 2.

253. 9/1 I COMMISSION REPORT, supra note 3, at 24.

254. Cf. KAISER, supra note 15 , at 18; but see Ott, supra note 92 , at 79-80.

255. See MCDonough ET AL., supra note 208, at 27 ("Congressional overseers-members and staff alike-do not know what they do not know."); Eric Lichtblau \& Scott Shane, Congressman Says Program Was Disclosed by Informant, N.Y. Times, July 10, 2006, at All (reporting letter by Chairman of the House Intelligence Committee to the White House complaining of the White House's failure to inform the Committee about particular intelligence activities); cf. Ransom, supra note 24, at 165 ("Congress has uneven access to the product of the intelligence system.").

256. Phillip B. Heymann, Terrorism, Freedom, and Security: Winning Without War $152-$ 56 (2003); Douglas Jehl, White House Has Tightly Restricted Oversight of C.I.A. Detentions, Officials Say, N.Y. TIMES, April 6, 2005, at A21 (noting that only the chairmen and ranking minority members of the House and Senate Intelligence Committees have been briefed on CIA detentions of allcged al Qaeda members). 
costs and benefits of particular committee structures, but further research must be done. The most effective committee structure likely is neither entirely unified nor entirely decentralized, but rather has a mixture of exclusive and shared committee jurisdiction. ${ }^{257}$

\section{Interaction Between Organization of Intelligence Community and Congressional Oversight}

Although delegation to the intelligence community generally precedes congressional oversight, Congress's decisions on what and how to delegate, and how to oversee agencies, do and should influence each other. This interaction of institutional design is critical to consider but is almost always neglected. One study by scholars interested in both preserving national security and protecting civil liberties concluded that the decentralization of counterterrorism functions prior to the Intelligence Reform Act had prevented the emergence of a "single oversight structure, not simply in Congress, but also within the executive branch."258 By contrast, if agencies are consolidated (or managed centrally) within the Executive Branch, they may require fewer congressional committees to oversee them. ${ }^{259}$ Members of Congress could focus on the consolidated or coordinating entity. On the other hand, if unified agencies are more likely to fail at their mission than redundant agencies, a redundant oversight structure where committees do not free-ride off efforts of other committees may get better work out of a unified intelligence community than a single committee could.

Because the structure of the intelligence community at least somewhat affects the effectiveness of congressional oversight, and vice versa, a national security planner should consider the structure of the intelligence community and its congressional overseers simultaneously. One way to think about the problem is as follows: assume the planner can choose decentralized or centralized intelligence agencies and decentralized or centralized oversight, as Figure 1 illustrates. The planner should determine the net benefits of each combination (and options in between the two poles) and choose the combination with the highest net benefits. That combination should provide net benefits at least as great as the net benefits obtained if the structural choice of one component (agencies or committees) were

257. This framework does not explicitly address transition costs in restructuring congressional oversight. See supra notes 203-204 and accompanying text.

258. HEYMANN \& KAYYem, supra note 100 , at 128.

259. Bendor, supra note 122, at 256; cf. Kenneth A. Shepsle \& Mark S. Bonchek, ANAlyzing Politics: RATIONAlity, Behavior, AND INSTitutions 359 (1997) ("Although there are bound to be occasions in which a bureau chief pulls the wool over a legislator's eyes, and there are surely times in which a department's budget people use 'blue smoke and mirrors' to misdirect congressional inspectors, it is unlikely... for these abuses to persist for very long-certainly not without the implicit approval of congressional players in the bureau's jurisdiction."). With the creation of the DNI, an enactment he opposed, Posner argues that unified congressional oversight probably would "strengthen the DNI's hand." PoSNER, supra note 1, at 63. 
set, and the planner could choose the structure of only the other component.

\section{B. Political Feasibility and Legal Constraints}

A second consideration in choosing among possible structures for the intelligence community and congressional oversight is their political and legal feasibility. Although intelligence has certain unique features as a policy area, it shares many attributes with other policy areas. ${ }^{260}$ Certain reforms might have a powerful impact on enhancing national security or advancing core liberal democratic values, but are incapable of drawing sufficient political support or precluded by law. ${ }^{261}$ Reform of the intelligence community and its congressional overseers "must come to terms with the political ambitions and motives of the actors involved, and with the institutional contexts in which these ambitions and motives get played out." ${ }^{, 62}$ What option or combination of options from Figure 1 is politically and legally viable in this country? Redundant structures are the most viable, at least for congressional oversight. Some unification has been possible for agencies, but redundancy remains and likely will continue to do so.

In many circumstances intelligence agencies and congressional committees would prefer to have exclusive authority over particular tasks. ${ }^{263}$ Having a monopoly in government confers certain benefits, just as it does in business. Agencies and committees typically do not want to give up power. ${ }^{264}$ This instinct to defend "turf" motivates much opposition to reforms. ${ }^{265}$ Nevertheless, political "entrepreneurs" may be able to use

260. See Stafford T. Thomas, Intelligence and the American Political System, in Controlling INTELLIGENCE 23, 44 (Glenn P. Hastedt ed., 1990). Like many other policy areas, intelligence can be considered a public good, which economists define as a good that is both non-rivalrous as well as nonexclusive, i.e., "a commodity or service whose benefits are not depleted by an additional user and for which it is generally difficult or impossible to exclude people from its benefits, even if the people are unwilling to pay for them." BAumol \& BLINDER, supra note 119, at G-8; see also Herman, supra note 196, at 313; Henry S. Rowen, Reforming Intelligence: A Market Approach, in U.S. INTELLIGENCE AT The Crossroads: Agendas for ReForm 232, 234 (Roy Godson et al. eds., 1995).

261. See Bruce D. Berkowitz \& Allan E. Goodman, Strategic Intelligence for American National Security xii (1989) ("Like it or not, the effectiveness of U.S. intelligence depends on how it is treated by the American political process.").

262. Shepsle \& BoncheK, supra note 259, at 296; see also David E. Lewis, Presidents and the Politics of Agency Design 6-7 (2003).

263. See James Q. Wilson, The Investigators: Managing FBI and Narcotics Agents 170 (1978) ("[FBI Director J. Edgar] Hoover knew instinctively what every natural executive knows: having a monopoly position on even a small piece of turf is better than having a competitive position on a large one.").

264. 9/I I Commission Report, supra note 3, at 403; see also Edward T. Jennings, Jr. \& Jo Ann G. Ewalt, Interorganizational Coordination, Administrative Consolidation, and Policy Performance, 58 Pub. Admin. Rev. 417, 418 (1998).

265. To be certain, political actors do not always seek more turf; additional authority may bring liabilities such as the potential for blame if that authority is not used well. See Daryl J. Levinson, Empire-Building Government in Constitutional Law, 118 HARv. L. REv. 916, 935 (2005). 
particular events, such as September 11, 2001, to garner support for shifting jurisdictional boundaries, despite agencies' and committees' vested interests. ${ }^{266}$ Further, the President and members of Congress may be willing to take away power from agencies because "cutting duplication" plays well to constituents. On the other hand, they may prefer agency duplication to consolidation if redundancy provides them with particular benefits. ${ }^{267}$ Even if structural changes to agencies and congressional committees have sufficient political support, they face certain legal constraints. These legal constraints are often minimal in practice. But, in certain circumstances, they may not only be more restrictive than the limits of political feasibility, but may also infringe upon organizational effectiveness in promoting national security and liberal democratic values.

Intelligence may be more isolated than other policy areas from some of these political and legal forces, ${ }^{268}$ but it is not completely divorced from them. ${ }^{269}$ The $9 / 11$ Commission recognized that there are political constraints on reorganizing the intelligence community and its congressional overseers. The Commission did not, however, explicitly address in meaningful detail how those constraints operated; rather, it seems to have assumed that such constraints would not be binding because of the perceived importance of national security. ${ }^{270}$ But the struggles over the Intelligence Reform Act show that even reforms proposed by a bipartisan, broadly legitimate body in the wake of a major national trauma can be difficult to enact. The most effective organization plan, in terms of national security, is useless unless it is legally and politically feasible.

This Section provides analytical tools for considering the political and legal feasibility of organizational change in the intelligence community and its congressional overseers; these tools can also apply to reorganizations of other areas of the administrative state. As in the previous discussion of national security effectiveness, the political and legal feasibility of a proposed structure of the intelligence community depends, at least to some degree, on the political and legal feasibility of any proposed reforms to the

266. Cf. Nelson W. Polsby, Political Innovation in america: the Politics of Policy INITIATION 67 (1984) (noting entrepreneurs' ability to take advantage of particular events to enact policy changes); Adam D. Sheingate, Political Entrepreneurship, Institutional Change, and American Political Development, 17 STudies IN AM. PoL. DEv. 185, 198 (2003) ("entrepreneurial innovation is a speculative act of creative recombination that, when successful, transforms the institutional boundaries of authority").

267. Agencies, of course, cannot take away congressional jurisdiction, at least formally, but functionally could do so by refusing to provide necessary information or to testify in front of particular committees.

268. SHEPSLE \& BONCHEK, supra note 259, at 375.

269. See ZEGART, supra note 194, at 7-9; 9/1 1 COMMISsION REPORT, supra note 3, at 403, 406.

270. See $9 /$ I I COMMISSION REPORT, supra note 3 , at 406,419 . 
structure of congressional oversight, and vice-versa. After all, Congress creates the bureaucracy, and largely oversees it. ${ }^{271}$

\section{Organization of the Intelligence Community}

To consider the political feasibility of various structures of the intelligence community, I build on the bureaucratic delegation model proposed by Mathew McCubbins, Roger Noll, and Barry Weingast. ${ }^{272}$ Figure 3 illustrates this model. The model examines a two-dimensional policy space. One axis represents a civil liberties dimension (less to more protection), while the other axis represents breadth of targets for intelligence collection (narrower to broader scope). In this policy space, the President, House, Senate, and an Agency (Agency 1) each have different ideal points. That is, each actor prefers a different combination of the two policy dimensions (for example, high civil liberties protection and wide breadth of intelligence targets). The triangle formed by the ideal points of the President, House, and Senate represents the "pareto set" of policies for those institutions. In other words, all players can realize an outcome closer to their ideal points by moving a policy outcome from outside to inside the triangle. Conversely, at least one player will be made worse off by moving a policy outcome from inside to outside the triangle.

The President and Congress establish a policy which is to be carried out by the Agency, inside the pareto set determined by their ideal points. Assume that after bargaining among themselves, the President and Congress choose policy $x$ for the Agency to enact. But the Agency will implement $x^{\prime}$, rather than $x$, because $x^{\prime}$ is the closest policy to the Agency's ideal point that is still within the triangle (this is called "bureaucratic drift"). The other actors permit this because correcting it would require them to take concerted action, and two of them-the President and the Senate-actually prefer $x^{\prime}$ to $x$. This is because in this model, ex post punishments must be unanimously imposed. This unanimity requirement derives from constitutional requirements: barring a presidential veto and necessary congressional override, any new legislation must pass both the House of Representatives and the Senate and be signed by the President. ${ }^{273}$ If the Agency implements a policy outside the triangle, however, all three players will want to move the policy to some point on or inside the triangle so they will take action together to move the agency back into line.

271. SHEPSLE \& BONCHEK, supra note 259 , at 359.

272. Mathew D. McCubbins et al., Structure and Process, Politics and Policy: Administrative Arrangements and the Political Control of Agencies, 75 VA. L. REv. 431 (1989).

273. U.S. CONST. art. I, $\S 7$. This assumption is a simplication of bureaucratic politics. Each actor has some ability to influence the agency on its own; for example, the President can fire many agency leaders without cause. 
Figure 3

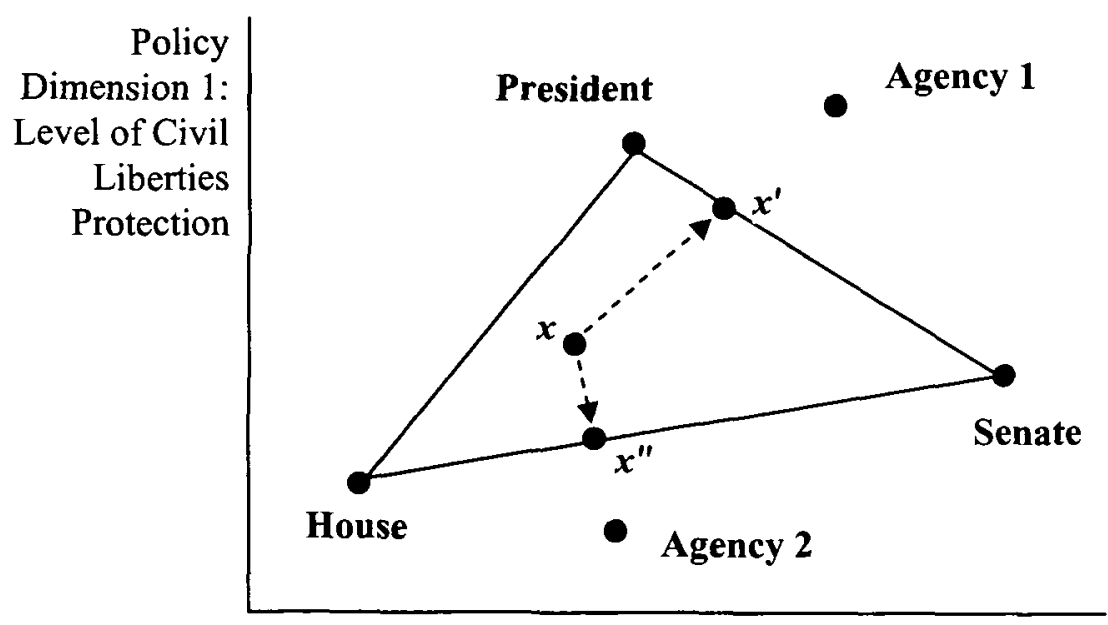

Policy Dimension 2: Breadth of Targets for Intelligence Collection

Within this model, the problem of bureaucratic organization (or reorganization) can be thought of as a two-part question: first, where should policymakers put one or more agencies in this policy space (in other words, how should they design an agency so that it has particular policy preferences, which determine the direction of bureaucratic drift), and second, to which agencies should policymakers delegate a particular task, if any? ${ }^{274}$ If there were no agency to implement the specific policy $x$, the House, Senate, and President likely would not create a new agency with the same ideal point as Agency 1. ${ }^{275}$ Instead, they would create an agency with policy preferences that placed it at point $x$ so it would implement exactly the

274. There is a vast literature in political science and economics about decisions to delegate to political agencies. See, e.g., David Epstein \& Sharyn O'Halloran, Delegating Powers: A Transaction Cost Politics Approach to Policy Making under Separate Powers (1999). The literature on agency creation is much smaller. See LEwIS, supra note 262, at 14; Moe, supra note 13, at 268; Terry M. Moe \& Scott A. Wilson, Presidents and the Politics of Structure, 57 L. \& ConTEMP. ProBs. 1 (1994).

275. See Richard W. Waterman, Presidential Influence and the Administrative State 40 (1989) ("Organizational structure is not neutral. The manner in which an agency or department is organized can have a major impact on policy outcomes."); Jonathan R. Macey, Organizational Design and Political Control of Administrative Agencies, 8 J. L. ECON. \& ORG. 93, 108 (1992) ("Agency structure and design reduce bureaucratic drift by ensuring that the interests of the agency reflect the interests of the members of the enacting coalition. Structure and design mitigate legislative drift by strengthening the groups that form the initial political coalition and weakening the groups outside the original compromise."). 
policy they had chosen with no bureaucratic drift. Why, then, is Agency 1 's ideal point in its current location? The model assumes that a previous political configuration established Agency 1, and that it is not politically feasible to restructure Agency 1 so that its ideal point for this policy moves.

Imagine that a second agency, Agency 2, exists and could implement the policy under consideration. Its policy preferences place it on the policy space as shown in Figure 3. Only the House prefers to delegate to Agency 2, rather than Agency 1, because the ultimate policy enacted by Agency 1 is closer to the ideal points of the President and Senate than is the ultimate policy enacted by Agency 2 , which is $x^{\prime \prime}$. All three may prefer, however, to delegate to both Agency I and Agency 2, if the ultimate outcome would fall between the outcomes of each agency acting alone, because that point would actually fall quite close to $x .^{276}$

But what drives the creation of agency structures? According to most political scientists, politicians' 'calculations about the 'proper' design of administrative agencies are shaped less by concerns for efficiency and effectiveness than by concerns about reelection, political control, and, ultimately, policy outcomes." ${ }^{277}$ Calculations by Presidents and members of Congress differ in fundamental ways. Presidents "seek control of the bureaucracy not only to influence public policy and meet public expectations but also because presidents are held accountable for their performance as managers." 278 All modern Presidents, in an effort to increase control over agencies, "ha[ve] attempted to reshape the bureaucracy by eliminating overlapping jurisdictions, duplication of administrative functions, and fragmented political control. ${ }^{279}$ Presidents also usually fight "attempts to insulate" agencies from their control, preferring to have agencies under their direct control. ${ }^{280}$ Nevertheless, although Presidents may be motivated to make agencies more effective, they often do not have or care to devote sufficient political resources to make necessary organizational changes. ${ }^{281}$

For example, President Bush initially opposed efforts to unify the intelligence community under a DNI, who is directly under his control. ${ }^{282} \mathrm{He}$ did this arguably because he wanted to protect the Defense Department's

\footnotetext{
276. See Macey, supra note 275, at 104.

277. LeWIS, supra note 262 , at 3 .

278. Id. at 4.

279. Id. (citing Peri E. Arnold, Making the Managerial Presidency: Comprehensive Reorganization Planning, I905-I996 (1998) and Herbert Emmerich, Federal Organization ANd Administrative Management (1971)); see also Niskanen, supra note 148, at 640 .

280. LEWIS, supra note 262, at 15.

281. Zegart, supra note 14, at 97 ("Tax cuts and Social Security lockboxes win votes but no [P]resident ever won a landslide election by changing the CIA's personnel system.").

282. Helen Fessenden, The Limits of Intelligence Reform, For. AFFalRs, Nov. /Dec. 2005, at 106,
} 110 . 
authority against incursions by the DNI and other intelligence agencies, at least one of which, the CIA, has more independence than other executive agencies. Perhaps President Bush feared that he would give up control of the intelligence community under the new system, or at least control about which he cared.

By contrast, members of Congress choose "redundant structures...more often as agency preferences coincide less with Congress" to prevent one less friendly agency from wielding too much control over policy decisions. ${ }^{283}$ In addition, Congress tends to create new agencies or split existing agencies when agencies demand more "bureaucratically provided services" than Congress. ${ }^{284}$ Conversely, Congress generally wants to give additional tasks to existing agencies or merge agencies if agencies demand fewer such services than Congress. ${ }^{285}$ Congress often uses "duplication, fragmentation, and overlap in the administrative state ... not ... to take auxiliary precautions or improve effectiveness via competition.... [but rather] to remove certain policies from presidential political influence." 286

Major restructuring of the intelligence community is hard to implement politically for a variety of reasons. First, and most critical, structural decisions "have important consequences for the content and direction of policy, and political actors know it." ${ }^{287}$ Members of the dominant party, if uncertain about their status in future years, likely will work to create structures that are insulated from future change. Members of the minority party will fight such insulation. ${ }^{288}$ Presidency scholars often contend that Presidents are less susceptible to these narrow, political interests and more drawn to "what is best for society." ${ }^{289}$ This seems questionable, as a general matter and also in the intelligence area. Intelligence agencies primarily serve the President, in that national security is a core area of presidential power. Cozy relationships between the agencies and top Executive Branch political appointees may form easily, and the President will find it particularly difficult politically to disrupt those relationships. ${ }^{290}$ Indeed, the

283. Ting, supra note 121 , at 286.

284. Michael M. Ting, A Theory of Jurisdictional Assignments in Bureaucracies, 46 AM. J. PoL. SCI. 364, 374 (2002).

285. Id.

286. LEWIS, supra note 262, at 7; see also id. at 11,164 .

287. Id. at 268; see also Heimann, supra note 152, at 433; Avery Leiserson, Political Limitations on Executive Reorganization, 41 AM. Pol. ScI. Rev. 68 (1947).

288. Moe, supra note 13 , at 277.

289. Id. at 279; see also LEWIS, supra note 262 , at 22,160 .

290. Presidents appear to prefer having access to multiple sources of information. See RiCHARD E. Neustadt, Presidential Power and the Modern Presidents 132 (1990) (noting that Franklin D. Roosevelt relied on competing sources of information to be effective); but cf. PosNer, supra note 1, at 116 ("Under the new system, with its concentration of unprecedented power in the [DNl], the other senior intelligence officials will be less influential; the President will have only one mind in the intelligence community to bend to his will."). 
intelligence agencies themselves, like all bureaucracies, are powerful opposition players in reorganization attempts. ${ }^{291}$ Thus, members of Congress, the President, and bureaucratic employees fight to advance particular political interests.

Second, reorganization presents a collective action problem. ${ }^{292}$ Members of Congress and the President answer to voters whose concerns are not limited to maximizing agency effectiveness. For example, the public rewards members of Congress partly for bringing funding to their districts. ${ }^{293}$ Members may decline to eliminate redundancy in the administrative state in order to retain "pork" for which they can claim credit, though this motivation seems less compelling for intelligence agencies whose many projects are kept secret. Members may refuse to support streamlining efforts by characterizing them as threatening national security, even if such efforts could in fact improve national security effectiveness. Members may also want to maintain their ability to influence particular policy outcomes, even if those outcomes do not yield financial benefits to their constituents. ${ }^{294}$ The President can, in some ways, take advantage of the inability of members to work collectively; he can create certain agencies on his own. ${ }^{295}$ The President, however, cannot terminate or significantly modify on his own an agency that Congress created. ${ }^{296}$ In any event, "[i]nertia of mature organizations is powerful ...."297 At certain times, such as after September 11, 2001, members of Congress and the President have acknowledged the collective action problem, by appointing commissions with mandates that include examining bureaucratic reorganization. ${ }^{298}$

Third, reorganization that increases redundancy is often not politically feasible. ${ }^{299}$ Because voters dislike "waste," policymakers typically see redundancy in government as undesirable, ${ }^{300}$ perhaps because they perceive

291. Bardach, supra note 185, at 352 .

292. See ZEGART, supra note 194, at 155.

293. John A. Ferejohn, Pork Barrel Politics; Rivers and Harbors Legislation, i947-ig68

(1974); David R. Mayhew, Congress: The Electoral Connection (1974).

294. See Merrill \& Francer, supra note 14, at 167.

295. LEWIS, supra note 262, at 15.

296. Cf. INS v. Chadha, 462 U.S. 919 (1983).

297. TREVERTON, supra note 174 , at 249.

298. See LEWIS, supra note 262, at 9. In cases of agency reform that affect large numbers of interest groups, the difficulty in forming coalitions may present an additional collective action problem. Larger coalitions are harder to form and to hold together. Sheingate, supra note 266, at 201. Interest groups, however, seem to be weaker in intelligence and national security matters than in other areas of government policy. See ZEGART, supra note 194.

299. Landau, Public Administration, supra note 110, at 11 ("That duplication and overlap are wasteful is a cardinal doctrine in public administration. If TWA and United Airlines duplicate each other, that is sound public policy. But if [public agencies] AC [Transit] and BART do so, something is wrong.").

300. BENDOR, supra note 122, at 236 (arguing that "anything that increases [redundancy's] visibility decreascs its viability"); Statement of Chairman William V. Roth, Jr., Duplication, Overlap, 
government services to be products of a natural monopoly, produced most efficiently by one supplier. The political branches sometimes terminate agencies to eliminate costs. ${ }^{301}$ Some commentators contend, however, that the events of September 11,2001 and the WMD intelligence failure in Iraq have provided public support for "maximiz[ing] coverage of problems." To the extent that voters perceive that there are multiple potential threats, they may be more likely to support redundancy in the intelligence community if such redundancy maximizes protection against attacks. ${ }^{303}$ In light of this public support, redundancy in the form of overlapping task delegation with different technologies - that is, assigning the same task to several agencies but having them employ different methods-may be more politically palatable than redundancy in the form of complete duplication. ${ }^{304}$

Fourth, to the extent that political actors will work together to implement structural change, such change will likely be, or be portrayed as, "dramatic," not "among the shades of gray," because "[p]olitical points are scored by painting issues in broad swaths of black and white." 305 Under this reasoning, larger reorganizations may be more plausible than "fine-tuning" of agencies because such fine-tuning does not generate a sufficiently large political payoff.

The 9/I I Commission implicitly incorporated some of these political constraints when it recommended that the deputies to its proposed National Intelligence Director (NID) be dual-hatted-working for both the NID and one of the intelligence agencies (the CIA, Defense Department, and FBI). ${ }^{306} \mathrm{Had}$ this recommendation been implemented, such dual-hatting might have mollified opposition somewhat by those three agencies and their supporters, because those agencies' interests would have been represented at the very top layer of the new organizational structure. The Commission did not, however, justify this proposal in political terms.

The President and Congress also face particular legal constraints in reorganizing the administrative state. These legal constraints can be broken down into constitutional and statutory requirements. The Constitution constrains administrative reorganization only minimally, almost entirely through the Appointments Clause and separation of powers principles. ${ }^{307}$ The Constitution "neither describ[es] nor empower[s] the administrative

and Fragmentation in Government Programs: Hearing Before Senate Comm. On Governmental Affairs, 104th Cong. (1995).

301. LEWIS, supra note 262, at 139-40.

302. Betts, New Politics, supra note 15 , at 6.

303. Cf. TREVERTON, supra note 174, at 225 (noting the "multiplicity of targets for intelligence").

304. Cf. BENDOR, supra note 122 , at 279 .

305. Betts, New Politics, supra note 15, at 2.

306. 9/11 COMMISSION REPORT, supra note 3, at 412 ("The National Intelligence Director would manage this national effort with the help of three deputies, each of whom would also hold a key position in one of the component agencies.").

307. U.S. ConsT. art 11, $\S 2$, cl. 2. 
state." 308 It largely leaves agency design decisions to the two political branches, through the Necessary and Proper Clause and the Take Care Clause, with limited judicial review. ${ }^{309}$ At the structural level, the Constitution appears to promote institutional redundancy. ${ }^{310} \mathrm{But}$ in the national security area, the Constitution may impose more constraints on how political branches organize and reorganize the nation's national security apparatus. Under a pro-Executive theory, one could argue that the Take Care Clause and the President's national security powers severely restrict Congress's power to reorganize the intelligence community. ${ }^{311}$ On the other hand, few commentators believe that Congress's reorganization of the military after World War II was unconstitutional. ${ }^{312}$ It is not clear, however, that intelligence agencies could be structured as independent agencies, such as the Federal Communications Commission.

The statutory requirements include both general limits on bureaucratic reorganization and specific limits related to intelligence. Under the Reorganization Act of 1977, as amended, the President may reorganize the bureaucracy in the following ways, so long as Congress approves his plan:

(1) the transfer of the whole or a part of an agency, or of the whole or a part of the functions thereof, to the jurisdiction and control of another agency;

(2) the abolition of all or a part of the functions of an agency, except that no enforcement function or statutory program shall be abolished by the plan;

(3) the consolidation or coordination of the whole or a part of an agency, or of the whole or a part of the functions thereof, with the whole or a part of another agency or the functions thereof;

308. LEwIS, supra note 262, at 167.

309. U.S. Const. art. I, $\S ~ 8$, cl. 18; art. 1I, § 3. See StePhen G. Breyer ET AL., Administrative LAW ANd Regulatory Policy 31-139 (6th ed. 2006). Most legal scholars contend that Congress has immense authority to design agencies. See, e.g., William F. Fox, JR., Understanding Administrative Law (1997). By contrast, some political scientists argue that the President wields considerable power. See, e.g., LEWIS, supra note 262; Moe, supra note 13. Intelligence reform may be somewhat unique as a constitutional matter. Because of its connection to national security, the President presumably has more power over the design of the intclligcnce community than over telecommunications regulators.

310. Landau, Redundancy, supra note 110, at 351 ("Look at it: separation of powers, federalism, checks and balances, concurrent powers, double legislatures, overlapping terms of office, the Bill of Rights, the veto, the override, judicial review, and a host of similar arrangements.").

311. See Russell J. Bruemmer, Intelligence Community Reorganization: Declining the Invitation to Struggle, 10I YALE L.J. 867, 884 (1992) ("The President might assert that any Intelligence Community reorganization could, and should, be effected solely through Executive order or other Presidential directive."); $c f$. Youngstown Sheet \& Tube Co. v. Sawyer, 343 U.S. 579 (1952).

312. Neal Kumar Katyal, Internal Separation of Powers: Checking Today's Most Dangerous Branch from Within, 115 YALE L.J. 2314, 2322-23 (2006) ("No one seriously suggests that Congress's division of the military into four separate services . . . is unconstitutional-despite the fact that the 1947 Act was passed because of a fear that a President might consolidate or eliminate one or more of the four."). 
(4) the consolidation or coordination of part of an agency or the functions thereof with another part of the same agency or the functions thereof;

(5) the authorization of an officer to delegate any of his functions; or

(6) the abolition of the whole or a part of an agency which agency or part does not have, or on the taking effect of the reorganization plan will not have, any functions. ${ }^{313}$

Subject to congressional approval, the President can eliminate or consolidate agencies, though he can neither abolish an executive department or independent regulatory agency nor combine departments or regulatory agencies. ${ }^{314}$ In addition, the President cannot create departments or freestanding agencies, or give new authority to an existing agency. ${ }^{315}$ Congress cannot amend the President's plans, which makes the process preferable (at least for the President) to the normal lawmaking process. ${ }^{316}$

The Reorganization Act reflects potentially conflicting purposes, including "to reduce expenditures and promote economy to the fullest extent consistent with the efficient operation of the Government," "to increase the efficiency of the operations of the Government to the fullest extent practicable," and "to eliminate overlapping and duplication of effort." ${ }^{917}$ As discussed in the previous Section, bureaucratic efficiency may, however, require redundancy of effort. Other statutes specific to intelligence also may constrain reorganization in this area. For example, statutes preclude the complete merging of foreign and domestic intelligence because this distinction is perceived as important for protecting civil liberties within our borders. ${ }^{318}$

Despite these political and legal constraints, however, agency jurisdictions do change. Agencies are created, modified, and eliminated, ${ }^{319}$ and the intelligence community has been reorganized, albeit rarely. The

313. 5 U.S.C. $\$ 903(\mathrm{a})(1)-(6)$ (2006). The Reorganization Act was amended in 1984 to eliminate its one-chamber legislative veto provision. See EEOC v. Westinghouse Electric Corp., 765 F.2d 389, 391 (3d Cir. 1985). The President now submits a reorganization plan to Congress, which takes effect once Congress passes a joint resolution; under the Act, the joint resolution receives "expedited consideration." Elizabeth Garrett, The Purposes of Framework Legislation, 14 J. ConTEMP. LEGAL 1ssUes $717,728 \&$ n.38 (2005).

314. 5 U.S.C. $\$ 905(\mathrm{a})(1)(2006)$.

315. Id. $\S 905(\mathrm{a})(4)-(5)$ (2006). The President can, however, create nonindependent agencies that do not have cabinet status to perform new functions by Executive Order. To be certain, another President could revoke the Executive Order, or Congress could refuse to fund such an agency. President Truman established the National Security Agency by a classified memorandum. RICHELSON, supra note 17, at 30-31.

316. See 5 U.S.C. $\$ \$ 903(c), 909$ (2006).

317. 5 U.S.C. $\S 901(a)(2),(3),(6)$ (2006). Presidential reorganizations do not appear to save significant amounts of money. See Louis Fisher \& Ronald C. Moe, Presidential Reorganization Authority: Is it Worth the Cost?, 96 PoL. ScI. Q. 301, 306 (1981).

318. TREVERTON, supra note 174, at 225; Lee \& Schwartz, supra note 181, at 1459, 1473.

319. LEWIS, supra note 262. 
Intelligence Reform Act, signed by President Bush in December 2004, brought considerable change. Such change was possible because of a confluence of factors. Most important, members of Congress faced political rewards for enacting a major recommendation of the 9/11 Commissionand likely faced political punishment for opposing change. The events of September I1, 2001 and the 9/11 Commission together helped members act collectively by providing the impetus to act and by recommending a reorganization plan to implement, respectively. ${ }^{320}$ As the next Section explains, this impetus did not extend to reorganization of congressional oversight.

\section{Organization of Congressional Oversight}

To analyze the political and legal feasibility of various structures for congressional oversight, one must carefully examine congressional committees. Committees that have "jurisdiction over issues have significant leverage over their resolution." 321 The Executive Branch operates in a wide range of policy areas. If Congress wants to influence and oversee the work of executive agencies, its members have to specialize; otherwise, members of Congress will "find themselves outmaneuvered at every turn by the executive branch." 322 Specialization occurs through the committee system. Congressional committees thus can be regarded as components of an institutional structure, that of Congress, which designs its internal governance to serve both individual members' interests and the structure's larger objectives. ${ }^{323}$

Political scientists have proposed three major theories of congressional committees. ${ }^{324}$ Some scholars consider congressional committees to be the result of a distributive system of spoils, serving to reelect members of Congress. ${ }^{325}$ Others view congressional committees as the result of an institution in need of information, serving to decrease uncertainty in the

\footnotetext{
320. Posner contends that it was politically necessary for President Bush to support the Commission's reorganization proposal because his opponent in the 2004 election, John Kerry, had endorsed it. PosNER, supra note 1, at 55. Zegart argues that CIA Director George Tenet's resignation, the Senate Intelligence Committee's report criticizing Iraq-related intelligence assessment, and the 9/1 1 Commission Report "converge[d] to make modest changes possible." Zegart, supra note 14, at 105.

321. SHEPSLE \& BONCHEK, supra note 259 , at 325.

322. Id. at 308 .

323. See id. at 311 .

324. See David Epstein \& Sharyn O'Halloran, Legislative Organization Under Separate Powers, 17 J.L. ECON. \& ORG. 373, 373-74 (2001) (summarizing scholarship). "All [of the theories] begin with a specification of members' core reelection needs and somc collective action problem they face in achieving these aims: majority cycling on distributive issues, informational asymmetries, or team production problems within parties. Each then derives an explanation of how the prevailing set of institutional arrangements, namely the system of strong committees, satisfies these needs by solving the particular problem at hand." Id. at 374.
}

325. Id. 
legislative process. ${ }^{326} \mathrm{~A}$ third view is that congressional committees are tools of the party system, working to advance the political parties' goals. ${ }^{327}$ Although legal scholars tend to emphasize the first, ${ }^{328}$ this Article does not choose among these positions concerning why Congress, as an institution, sets up committees; it focuses instead on why committee structure is so difficult to change.

Under any of these theories, changing committee structures is difficult for a variety of reasons, including that transaction costs of change are high. ${ }^{329}$ Committees become "equilibrium institutions," stable outcomes of political games, that are quite impervious to change. ${ }^{330}$ To assess the political feasibility of changes to committee structure, therefore, one must study historical and current committee organization. To change committee jurisdictions, the House and Senate typically must change their internal rules or pass free-standing resolutions that function as "standing orders." 331

None of the committees with jurisdiction over intelligence issues is likely to give up its turf easily. ${ }^{332}$ Each is more likely to try to expand its authority, for example, to get jurisdiction over more high-profile areas. ${ }^{33}$ In response, other committees that exercise similar jurisdiction are likely to contest these attempts at expansion. ${ }^{334}$ As a political matter, members of Congress typically find it harder to agree to change their own jurisdictional boundaries than to change those of administrative agencies. ${ }^{335}$ The 9/1 I Commission recommended that many committees relinquish jurisdiction, which means that many members have an incentive to block the proposal. The Commission partially acknowledged this political difficulty when it recommended that its proposed unified intelligence committee(s) not have power to fund intelligence agencies (i.e., appropriations authority), but rather that a new intelligence subcommittee be formed within the

326. Id.

327. $I d$.

328. See, e.g., Lawrence Lessig \& Cass R. Sunstein, The President and the Administration, 94 Colum. L. Rev. 1, 105-06 (1994); Mark Seidenfeld, A Big Picture Approach to Presidential Influence on Agency Policymaking, 80 IowA L. Rev. 1, 11-12 (1994); Peter Strauss, The Place of Agencies in Government: Scparation of Powers and the Fourth Branch, 84 ColuM. L. Rev. 573, 650 (1984).

329. E. Scott Adler, Why Congressional Reforms fail: Reelection and the House COMmitTeE SYSTEM 24 (2002). For example, it takes considerable resources to negotiate new structures.

330. Kenneth A. Shepsle, Institutional Equilibrium and Equilibrium Institutions, in POLITICAL Science: The Science of Politics 51, 51 (Herbert Weisberg ed., 1986).

331. See RUNDQUIST \& DAvIs, supra note 92, at 5.

332. See David C. King, The Nature of Congressional Committee Jurisdictions, 88 AM. PoL. SCI. REV. 48, 48 (1994).

333. See KING, supra note 210 , at 105-20

334. Id.

335. See Oleszek, supra note 206, at 197; see also Energizer Bunnies, N.Y. Times, Dec. 31, 2004, at A26 ("The main recommendation [of the 9/11 Commission], for fewer committees and a more focused panel with hands-on power over intelligence budgeting, clearly lies beyond the present level of selfishness bristling among traditional committee leaders."). 
Appropriations Committee in each chamber. ${ }^{336}$ Such an arrangement would likely garner more support from members than complete consolidation, as it would require less shifting of committees' current jurisdictions.

In addition to political constraints, changes in congressional oversight must also satisfy legal requirements. Congressional committees have a statutory obligation to "review and study" intelligence agencies. ${ }^{337}$ Committees, however, cannot exercise this oversight mandate in a way that violates constitutional separation of power principles. Then-Senator David Boren (D-OK) warned that the "activities of the [intelligence] oversight committees.... are inherently controversial; the mere existence of the committees in some ways circumscribes the power of the Presidency." 338 Intelligence officials could refuse to submit to congressional oversight in certain circumstances, asserting that the need to preserve secrecy in national security matters or that the President's powers as Commander in Chief trumped the legislature's powers under Article I. ${ }^{339}$ Nevertheless, there are few explicit legal constraints on congressional committee structure. ${ }^{340}$

Committee jurisdictions do change, but rarely without a major outside event such as September 11, 2001. ${ }^{341}$ Under the Legislative Reorganization

336. See 9/I I COMMISsion RePORT, supra note 3, at 421 .

337. Legislative Reorganization Act of 1970, 2 U.S.C. $\$ 190 \mathrm{~d}$; see also Legislative Reorganization Act of 1946, 60 Stat. 837 (duty of "continuous watchfulness").

338. Boren, supra note 169 , at 858 .

339. In Watkins v. United States, the Supreme Court discussed the limits of congressional oversight:

There is no general authority to expose the private affairs of individuals without justification in terms of the functions of Congress.... Nor is the Congress a law enforcement or trial agcncy. These arc the functions of the executive and judicial departments of government. No inquiry is an end in itself; it must be related to, and in furtherance of, a legitimate task of Congress.

354 U.S. 178, 187 (1957). See also Philip P. Frickey, Getting from Joe to Gene (McCarthy): The Avoidance Canon, Legal Process Theory, and Narrowing Statutory Interpretation in the Early Warren Court, 93 CALIF. L. REv. 397, 422-23, 455-56 (2005). In intelligenee, congressional oversight is mainly governed by the National Seeurity Act, as amended by the Intelligence Authorization Act for Fiscal Year 199I. Specifically, the "President shall cnsure that the intelligence committees are kept fully and currently informed of the intelligence activities of the United States," except to protect covert operations in extraordinary circumstances and "sensitive sources and methods." 50 U.S.C. $\S 413$ (2006); Bruemmer, supra note 311, at 874-76; see also JoHNSON, supra note 14, at 112-13 (discussing ability of President to report to eight members of Congress, the "Gang of Eight," instead of the Intelligence committees); Seymour M. Hersh, The Iran Plans, New Yorker, Apr. I7, 2006, at 30, 33 (citing apparent ability of military to engage in covert operations without reporting to anyone in Congress, including the "Gang of Eight").

340. SHEPSLE \& BONCHEK, supra note 259, at 181 ("A political executive may complain of the impossibility of simultaneously satisfying so many masters, but to no avail; the system works this way, not merely because legislators like it, but because that is how the framers of the Constitution designed it.").

341. See Ransom, supra note 24 , at 162. 
Act of 1946, Congress significantly consolidated its committees. ${ }^{342}$ Members of Congress supported the changes so that they would bc less likely to be placed on "inactive and irrelcvant panels" and more likely to have committee assignments that "would help to ensure their effectiveness in managing policy development." ${ }^{343}$ 1n the early 1970s, the House extensively considered major proposed reforms to its committee structure. ${ }^{344}$ Concern for jurisdictional turf, however, was unavoidable. The House ultimately implemented only a few reforms, such as the consolidation of many transportation matters under the Public Works Committee. ${ }^{345}$ In 1994, Republicans campaigned on promises that they would eliminate wasteful redundancy in the government, including redundancy in the congressional committee system. Only modest changes, however, occurred once they swept into office. ${ }^{346}$ In the end, they eliminated only three standing committees; ironically, the jurisdictions of the eliminatcd committees had not overlapped significantly with those of other committees. ${ }^{347}$

This brief history demonstrates that proposed reform to the committee structure may improve effectiveness, but it must garner political support to be enacted. In the intelligence area, members of Congress introduced over 200 bills between the creation of the CIA in 1947 and 1975 to "expand the system for congressional supervision of the intelligence community." 348 Only one was enacted. ${ }^{349}$ Subsequently, the Intelligence Committees were established in the late 1970s.

The Senate did modify its committee structure in several ways after the $9 / 11$ Commission's report. ${ }^{350}$ It moved its Intelligence Committee to

342. King, supra note 332 , at 55; Huzar, supra note 194, at 303 . The House reduced its standing committees from forty-eight to nineteen; the Senate similarly downsized, from thirty-three to fourteen standing committees. ADLER, supra note 329, at 118. This consolidation was a less impressive political feat than the numbers may suggest, however. $I d$. ("Many of the committees whose policy purviews were merged into larger committees with broader jurisdictions were almost completely inactive and frequently described as 'hangovers of lively legislative issues long since settled' or 'ornamental barnacles on the ship of state."').

343. ADLER, supra note 329 , at 123.

344. Id. at 144. These reforms were driven by some members' belief that the committee system was inefficient and needcd to be changed. $I d$. at 147 . One leading proponent of reform, Richard Bolling (D-MO), "went to great effort to rcmove constituency or reelection considerations from decision making concerning committee reforms proposals." Id.

345. Id. at 157.

346. These included eliminating a handful of committces, establishing caps on the number of subcommittees, and imposing term limits for committee chairs. Id. at 187. They were unable to implement fully the promise in their "Contract with America" to cut the number of House committees by one-third. Id. at 182; Ed Gillespie \& Bob Schellhas, Contract with AMerica 8 (1994).

347. ADLER, supra note 329, at 2, 191. The District of Columbia, Merchant Marine and Fisheries, and the Post Office and Civil Service Committees were eliminated. Id. at 191.

348. Ransom, supra note 24 , at 162.

349. Id.

350. See supra notes $92-94$ and accompanying text. S. Res. 445 did not, however, formally amend the Senate's Rules, which would have required a higher number of Senators to invoke cloture. RuNDQUIST \& DAvIS, supra note 92, at 5. 
category "A" status; Senators can serve usually on no more than two "A" committees. ${ }^{351}$ It also voted to create an Oversight Subcommittee of the Intelligence Committee, establish an Intelligence Subcommittee of its Appropriations Committee, and change the name of its Govcrnmental Affairs Committee to the Committee on Homeland Security and Governmental Affairs. ${ }^{352}$ Although these modifications are relatively small, the Congressional Rescarch Serviee called them "the most significant changc in Senate [Intelligence] [C]ommittee operations since 1977." "353 Senators, however, protected some committees' turf by explicitly not placing agencies such as the Secret Service, the Transportation Security Agency and the Coast Guard under the new Homcland Security and Governmental Affairs Committee. ${ }^{354}$

Will there be more change to committees with jurisdiction over intelligence? The 9/11 Discourse Project's final report card or a future terrorist attack may motivate members of Congress on various committees to relinquish jurisdiction over the intelligence community, so that intelligence oversight can be consolidated into fewer committees. Alternatively, if members of Congress perceive proposed reforms as necessary if they are to oversee and sometimes confront the Executive Branch, future divided government might help majority party leaders to reform committee jurisdictions. ${ }^{355}$ The collective action problem preventing organizational change may also be eased by compensating members who stand to lose committee seats in some way. ${ }^{356}$

This discussion presumes that members want to serve on committees overseeing the intelligence community. That may or may not be a correct assumption. ${ }^{357}$ The public may punish members for intelligence failures but not reward them for intelligence successes, because failures get more press and public attention than successes, which often remain secret. ${ }^{358}$ Members,

351. S. Res. 445, 108th Cong. (2004); RUNDQUIST \& DAvis, supra note 92, at 1-2.

352. S. Res. 445, 108th Cong. (2004); WMD REPORT, supra note 10, at 338 n.5; RuNDQUIST \& DAvis, supra note 92, at 1-2. The House Intelligence Committee still has six-year term limits for its members. 9/I i Public Discourse Project, supra note 89, at 8.

353. RUNDQUIST \& DAVIS, supra note 92 , at 5.

354. S. Res. 445, 108th Cong. (2004).

355. ADLER, supra note 329 , at 31 .

356. Id. at 222 (" $[\mathrm{R}]$ eformers must be able [to] convince their colleagues that changes will either enhance their abilities at representation or will come with some kind of concessions or offsets that can provide assistance in their reelection strategy."); cf. King, supra note 332, at 55 (noting that some committee members who lost seats in the 1946 reform were promised seats on more prestigious panels).

357. See Ott, supra note 92 , at 89.

358. See Treverton, supra note 33, at 88; cf. JoHnson, supra note 24, at 109 (finding better attendance at public intelligence hearings than private hearings but little difference in the styles of questions); John Ward Anderson \& Karen DeYoung, Plot to Bomb U.S.-Bound Jets Is Foiled, WAsH. Post, Aug. 11, 2006, at A1; David E. Sanger, 10 Plots Foiled Since Sept. Il, Bush Declares, N.Y. Times, Oct. 7,2005 , at A1. 
however, may want to serve on intelligence-related committees for a variety of reasons. ${ }^{359}$ Such service provides foreign policy or other credentials or an aura of seriousness to members seeking higher office. ${ }^{360}$ In addition, if members' districts include military or intelligence installations, then members' participation on committees with jurisdiction over the intelligence community, such as the Armed Services and Intelligence Committees, may bring some "pork" or other benefits to those members" districts. $^{361}$ At the least, such committee assignments provide "opportunities for national press coverage on high-profile issues about which very few people will be conversant." ${ }^{1362}$ Even if participation does not bring financial or electoral benefits, it may still bring psychological benefits of knowledge, power, and prestige to members and of safety and security to constituents. ${ }^{363}$ If members on intelligence-related committees did not care about maintaining their committee jurisdictions, presumably they would have adopted the $9 / 11$ Commission's recommendations for reform, earning praise from the 9/I I Public Discourse Project, national newspaper editorial pages, and others. Because they have not adopted the Commission's recommendations concerning congressional oversight, it is reasonable to infer that members benefit significantly from the existing committee structure.

\section{Interaction Between Organization of Intelligence Community and Congressional Oversight}

The political feasibility and the legality of changes in the structure of the intelligence community depend to some degree on the political and legal realities of changes to congressional oversight, and vice versa. If many congressional committees have some jurisdiction over the intelligence community, it will be hard to get members of Congress to agree to consolidation in the intelligence community because they will have formed close relationships with individual components through their oversight functions. Or if the intelligence community is made up of many decentralized components, Congress's watchfulness duty under the Legislative Reorganization Act may require it to assign multiple congressional committees intelligence jurisdiction, so that they can conduct adequate

359. See Lowenthal, supra note 243, at 148; Tim Groseclose \& Charles Stewart III, The Value of Committee Seats in the House, 1947-91, 42 AM. J. PoL. SCr. 453, 463 (1998) (determining that among standing committees Armed Services and Foreign Affairs rank highly as desired committee assignments).

360. In the 1980s, moderate Senate Democrats apparently sought spots on the Intelligence Committee "as a way to become active in foreign affairs without acquiring the liberal taint of the Foreign Relations Committee." Treverton, supra note 33, at 80.

361. See ADLER, supra note 329, at 66-67.

362. LOWENTHAL, supra note 243 , at 148.

363. See KING, supra note 2 I0, at 2; LowENTHAL, supra note 243 , at 148 ; SMIST, supra note 220 , at 273; Treverton, supra note 33 , at 88 . 
oversight. To some degree, ex ante constraints on delegation and ex post monitoring devices serve as substitutes; as oversight becomes more effective in meeting legislators' objectives, the design of agencies becomes less important. $^{364}$

Policymakers cannot consider the organization of these components in a vacuum. Change to any component will be politically difficult, because of the desire of bureaucrats and political actors to cling to their turf. Nevertheless, Congress unified the intelligence community through the Intelligence Reform Act, meaning that this reform was politically feasible, at least in the light of September 11, 2001 and other factors. Will change to congressional committees follow? The preceding analysis suggests that such change will be considerably harder to enact than the Intelligence Reform Act.

\section{Core Liberal Democratic Values}

Protecting important values fundamental to our society is a third consideration for choosing among organizational structures. What are the implications of the possible combinations of redundancy and unification illustrated in Figure 1 for such values as civil liberties, transparency, and accountability? This is a vital question for, at the extreme, " $[t]$ he threat that the intelligence state poses, at the end of the day, is to democracy itself." 365 This third perspective tracks the first perspective analyzed in Section II.A in that both consider the effectiveness of particular structures. The first perspective considered the effectiveness of structural choices for national security; this third perspective assesses the effectiveness of these choices in preserving critical constitutional and democratic values and any dangers these options pose to them. It appears that a more redundant system, at least for congressional oversight, may best protect core liberal principles.

The structure and oversight of the intelligence community affects at least three categories of core values: civil liberties, transparency, and accountability. These sets of values overlap. For example, transparency may help improve accountability, which may help preserve important civil liberties. Addressing each category separately, however, clarifies potential effects of structural choices.

Civil liberties encompass a set of constitutional and normative democratic concerns. One key principle in this category is due process: that individuals should not suffer deprivations without adequate process of law. This principle, enshrined in, but not limited to, the Fifth and Fourteenth

364. See Kathleen Bawn, Choosing Strategies to Control the Bureaucracy: Statutory Constraints, Oversight, and the Committee System, 13 J.L. ECON. \& ORG. 101 (1997).

365. Lee \& Schwartz, supra note 181 , at 1456. 
Amendments, helps prevent arbitrary governmental action. ${ }^{366}$ In addition, individuals may not be treated differently based on particular characteristics unless such different treatment is justified in certain, important ways. ${ }^{367}$ This equal protection value, also rooted in the Fifth and Fourteenth Amendments, works to combat discrimination.

The First Amendment also protects important civil liberties, including freedom of expression and belief, especially political and religious. In almost all circumstances individuals should be able to hold and express nearly any view and petition the government on the basis of it without fear of repercussions. They must have similarly broad freedom to practice their religion, or abstain from religious practice. These principles help prevent government policy that would chill expression, lessen the diversity of voices in the polity, and undermine citizens' control of their government. ${ }^{368}$

Respect for individual privacy from government intrusion protects against specific infringements in the criminal context and more broadly. This protection, expressed in the First, Third, Fourth, Fifth, and Ninth Amendments and their penumbras, carves out aspects of life that remain free of government intrusion. ${ }^{369}$ In sum, as civil liberties advocates argue, "In responding to terrorism, ... . we must adhere to the principles of political freedom, due process, and the protections of privacy that constitute the core of a free and democratic society." $" 370$

A second core democratic value is transparency. Transparency refers to the availability of information about government policies, structures, and actions. ${ }^{371}$ This information helps citizens (and others) assess and attempt to change their government's performance. ${ }^{372}$ One prominent theory of government expresses the relationship between those who govern and

366. Hamdi v. Rumsfeld, 542 U.S. 507, 528-37 (2004); see Mathews v. Eldridge, 424 U. S. 319, 332 (1976).

367. See, e.g., United States v. Virginia, 518 U.S. 515 (1996); Romer v. Evans, 517 U.S. 620 (1996); Loving v. Virginia, 388 U.S. 1 (1967).

368. See, e.g., McIntyre v. Ohio Election Comm'n, 514 U.S. 334 (1995); New York Times v. United States, 403 U.S. 713 (1971).

369. See, e.g., Griswold v. Connecticut, 381 U.S. 479, 482-86 (1965).

370. David Cole \& James X. Dempsey, Terrorism and the Constitution: Sacrificing Civil Liberties IN THE NAME of National SECuRity 1 (2002).

371. Ana Bellver \& Daniel Kaufmann, Transparenting Transparency, at 4 (Aug. 2005) (unpublished manuscript on file with author), available at http://papers.ssm.com/sol3/ papers.cfm?abstract_id=808664 (citing the following definitions of transparency: "increased flow of timely and reliable economic, social and political information which is accessible to all relevant stakeholders" and "release of information by institutions that is relevant to evaluating those institutions") (internal quotation marks ounitted); see also Mark Fenster, The Opacity of Transparency, 91 IOWA L. REv. 885, 888 (2006) (defining transparency as "a governing institution's openness to the gaze of others").

372. See Meredith Fuchs, Judging Secrets: The Role Courts Should Play in Preventing Unnecessary Secrecy, 58 ADMiN. L. REV. 131, 140-41; cf. Bellver \& Kaufmann, supra note 371, at 2 (transparency "not only increases the efficiency in the allocation of resources but also ... may help in ensuring that the benefits of growth are redistributed and not captured by the political elite"). 
those who are governed as one between agents and principals. Much like shareholders in a corporation, citizens elect representatives to govern as their agents. Citizens need information about their agents' actions to ensure that those agents follow their preferences. ${ }^{373}$ In addition, with increasing globalization and interdependence among countries, a democratic government's actions arguably should be transparent not only to voters, but also to noncitizen residents and people in other countries affected by those actions. $^{374}$

The value of transparency is enshrined in the Constitution and federal law. Article I requires that the House and Senate keep and publish journals of their proceedings, record their members' votes in certain circumstances, and publish information on appropriations. ${ }^{375}$ Article II mandates that the President "from time to time give to the Congress Information of the State of the Union," 376 and empowers him to require opinions from his principal officers. ${ }^{377}$ The Fourth Amendment requires particular warrants; ${ }^{378}$ the Sixth Amendment requires that criminal trials be open to the public. ${ }^{379}$ Laws such as the Freedom of Information Act, ${ }^{380}$ the Government in the Sunshine Act, ${ }^{381}$ and the Administrative Procedure Act $^{382}$ provide access to government policies and actions and manifest the importance of transparency in the federal government.

Intelligence is inherently a secretive policy area. Nevertheless, not all government action related to intelligence needs to be completely hidden. Democracy "requires accountability with full disclosure at least to representative groups in Congress." ${ }^{383}$ The government may need to restrict the dissemination of particular details, but it should withhold only information that must be kept secret for specific, articulable reasons. The intelligence community and its congressional overseers should be organized in ways that enable citizens and others affected to know about intelligence actions. For example, the $9 / 11$ Commission and others have called for the budgets of intelligence agencies to be made public. ${ }^{384}$ It is difficult to imagine how the disclosure of such aggregate information could endanger national security or interfere with the agencies' work except by subjecting them to an

373. Id. at 12 (transparency "allow[s] different social groups to participate in the decision-making process”); $c f$. New York Times Co. v. Sullivan, 376 U.S. 254, 305 (1964) (Goldberg, J., concurring) (quoting Louis Brandeis's comment that "sunlight is the most powerful of all disinfectants").

374. Fenster, supra note 371 , at 901 .

375. U.S. Const. art. $1, \S \S 5,9$.

376. Id. art. $1 \mathrm{I}, \S 3$.

377. Id. art II, $\$ 2$.

378. Id. amend. IV.

379. Id. amend. Vl.

380. 5 U.S.C. $\$ 552(2006)$.

381. 5 U.S.C. $\$ 552 \mathrm{~b}$ (2006); see also BERKOWITZ \& GOODMAN, supra note 261, at xi.

382. 5 U.S.C. $\$ \S 551$ et seq. (2006).

383. Ransom, supra note 24 , at 165 .

384. 9/I 1 CommisSION RePORT, supra note 3, at 4l6; Treverton, supra note 174, at 253. 
evaluation of their cost effectiveness that seems entirely appropriate in a democratic society.

There are other limits to transparency. It may "unduly empower [interest groups] representing minority interests at the expense of overall welfare" because such groups are more organized. ${ }^{385}$ For example, the availability of details of agency budgets may encourage rent-seeking behavior by powerful groups. ${ }^{386}$ Transparency also may inhibit full deliberations within the government because officials may fear that their frank discussions, if released, would generate negative repercussions. ${ }^{387}$ Finally, transparency about intelligence failures may sometimes produce public anxiety that can lead to support for constraints on civil liberties. Thus, complete transparency is not necessarily beneficial for democratic governance.

A third core value is democratic accountability. Democratic accountability addresses the repercussions of government action: government officials must answer for their actions and may suffer penalties for "misbehavior" or receive rewards for "good behavior," both genuine and perceived. ${ }^{388}$ Accountability guarantees responsiveness, although not necessarily effectiveness. ${ }^{389}$ This core value is embedded in both the Constitution and liberal democratic theory. The Constitution creates accountability structures internal to the federal government. It establishes a system of separate powers that check and balance each other. The impeachment provision enables the removal of government officers. ${ }^{390}$ The Constitution also makes government officials accountable to external groups. The most important group is the electorate: leaders of the Executive and Legislative Branches face regular elections. ${ }^{391}$ In addition,

385. Elizabeth Garrett \& Adrian Vermeule, Transparency in the Budget Process, at 1 (Feb. 2006) (unpublished manuscript on file with author), available at http:/papers.ssrn.com/ sol3/papers.cfm?abstract_id $=877951$.

386. Id.

387. The "deliberative process" privilege, which applies only to the government, protects predecisional agency communications (i.e., "antecedent to the adoption of an agency policy," Jordan v. United States Dep't of Justice, 591 F.2d 753, 774 (D.C. Cir. 1978) (en banc)) that are "a direct part of the deliberative process in that [they] mak[e] recommendations or expres[s] opinions on legal or policy matters." Vaughn v. Rosen, 523 F.2d 1136, 1143-44 (D.C. Cir. 1975).

388. See Edward Rubin, The Myth of Accountability and the Anti-Administrative Impulse, 103 MiCh. L. REv. 2073, 2119 (2005).

389. Cf. SHEPSLE \& BoNCHEK, supra note 259, at 213. Mashaw draws on Gunther Teubner's categories of "efficacy, responsiveness, and coherence" to identify the following six features of his "accountability regime": "who, to whom, about what, through what processes, by what standards and with what effects." Jerry L. Mashaw, Structuring a "Dense Complexity": Accountability and the Project of Administrative Law, 2005 Issues In Legal SchOlarship, Article 4, at 13, 17 (2005).

390. U.S. ConsT. art. $1, \S 3$.

391. Id. art. 1, $\S \S 2,3$, art. II, \& I; Richard H. Pildes, Competitive, Deliberative, and RightsOriented Democracy, 3 Election L.J. 685, 686 (2004) (reviewing Richard A. Posner, LaW, Pragmatism, and Democracy (2003)) ("Elections tie, however loosely, the exercise of public power 
the First Amendment protects freedom of the press and the right to petition the government, facilitating accountability outside the electoral process. Various tools governing the administrative state, such as the Administrative Procedure Act, also help hold agencies accountable. ${ }^{392}$ Accountability is also a construct of democratic theory, of course: government officials ultimately are responsible to those they represent, the citizenry. ${ }^{393}$

In analyzing the various options for the structure of the intelligence community and its congressional overseers, policymakers must consider their impact on at least these three categories of liberal democratic values-civil liberties, transparency, and accountability. The following two Sections consider the complexities of this analysis.

\section{Organization of the Intelligence Community}

Structural choices of the intelligence community interact with these core constitutional and democratic values in complicated ways. Policymakers have considered civil liberties to varying degrees during each restructuring of the intelligence community. At times, Congress has used civil liberties concerns to limit agency authority. The National Security Act of 1947 created the CIA, but prohibited it from exercising any "police, subpoena, or law enforcement powers or internal security functions." 394 Other times, Congress has largely ignored civil liberties concerns. The USA PATRIOT Act almost completely erased the line between intelligence gathering and law enforcement. ${ }^{395}$ And, sometimes, Congress pays mixed attention. The Intelligence Reform Act created a Privacy and Civil Liberties Oversight Board, as the 9/1 I Commission recommended. ${ }^{396}$

to the interests and values of citizens.... At a minimum, elections make the identity of those who wield public power accountable to the vote of citizens.").

392. Rubin, supra note 388, at 2129-30.

393. Mashaw, supra note 389 , at 4.

394. 50 U.S.C. $\$ 403-3(d)(1)(2006)$.

395. See U.S. DeP't OF Justice, RePort fRom THE FIELd: The USA PATRIOT ACT AT Work 25 (2004). Strong proponents of civil liberties generally oppose the elimination of a barrier between intelligence investigations and criminal investigations. See, e.g., COLE \& DEMPSEY, supra note 370, at 165; HeYMANN, supra note 256, at 140.

396. IRA, § 1061, 118 Stat. at 3684-85; 9/I I CommIssion, supra note 3, at 395. Civil liberties advoeates have called the Board "a toothless panel." Reforms at the F.B.I. and Justice, supra note 86, at A16. President Bush named its members in June 2005, and waited three more months to send the nominations of the chair and vice chair to the Senate for confirmation. See Press Release, Office of the Press Secretary, The White House, Nominations Sent to the Senate, (Sept. 28, 2005), available at http://www.whitehouse.gov/news/releases/2005/09/20050928-6.html; Press Release, Office of the Press Secretary, The White House, Personnel Announcement, (June 10, 2005), available at http://www.whitehouse.gov/news/releases/2005/06/20050610.html. The Board met for the first time in March 2006. White House Privacy and Civil Liberties Oversight Board, http://www.whitehouse.gov/privacyboard; Shane, supra note 83. The Board's ordinary members do not require Senate confirmation. IRA $\S 1061$ (e), 118 Stat. at 3686-87. The President appointed the DNI's Civil Liberties Protection Officer, mandated by the Intelligence Reform Act, in December 2005. HouSE Permanent Select Committee on Intelligence Subcommittee on Oversight, supra note 77, at 2I. 
The 9/11 Commission's structural recommendations for the intelligence community, as largely enacted by the Intelligence Reform Act, likely affect civil liberties, but exactly how is uncertain. On the one hand, redundant structures may promote civil liberties, and unified structures may undermine them. In Federalist No. 10, Madison warus against one faction garnering so much power that it threatens the liberal democratic system. ${ }^{397}$ Multiple agencies may prevent a culture hostile to civil liberties from taking hold in the intelligence community. If each agency wants to be seen as the most respectful of civil liberties, the agencies may "race to the top," ratcheting up their respect for civil liberties in competition with each other. If intelligence agencies are unified, with much redundancy eliminated, the resulting consolidated agency would wield great power. The ACLU has argued that centralization of power in the intelligence community "risks a re-run of the abuses that led to Watergate," including "widespread spying on ordinary Americans and illegal covert operations." ${ }^{3398}$ The ACLU also contends that the National Counterterrorism Center's authority to plan intelligence operations risks undermining First Amendment and other protections if these operations take place within the United States. ${ }^{399}$ The ACLU does not, however, oppose all centralization within the intelligence community; it endorsed an independent National Intelligence Director who would not report directly to the White House. ${ }^{400}$

On the other hand, redundant structures may undermine civil liberties, and unified structures may promote them. Redundant intelligence agencies could "race to the bottom" in their respect of civil liberties, increasingly sacrificing such values as they compete to achieve particular intelligence goals and to receive budgetary and other rewards. More agencies conducting intelligence work that can easily infringe on civil liberties may create more opportunities for abuse. Finally, uniform treatment is important in the area of civil liberties. Redundant agencies are more likely to develop different policies related to civil liberties than a single unified agency, risking inconsistent treatment of individuals. ${ }^{401}$

397. The Federalist No. Io (James Madison). See also Thomas, supra note 135, at 469 (prescribing wide distribution of power within the federal government to ensure against dominance by any single faction and noting that "[t]hus, organizational structures which protect personal liberty necessarily create impediments to coherent and coordinated national policy").

398. Timothy H. Edgar, ACLU Analysis of the 9-11 Commission's Recommendations for Intelligence Reform (July 30, 2004), available at http://www.aclu.org/natsec/emergpowers/ 14501 leg20040730.html; cf. PoSNER, supra note 1, at 57 ("lt is odd ... that liberals would favor a measure intended to make the intelligence system more of a monolith; one would think they' $d$ want to preserve some internal checks and balances by keeping the system decentralized and in particular that they would want to keep domestic and foreign intelligence separate.").

399. Edgar, supra note 398.

400. Id. The ACLU and other civil liberties advocates oppose the creation of a National Security Service within the FB1. See Eggen \& Pincus, supra note 85, at A1, A7; Intelligence Shuffle, WASH. Post, July 4, 2005, at A1; Reforms at the F.B.I. and Justice, supra note 86, at A16.

401. Cf. Robert A. Kagan, Adversarial Legalism: The American Way of Law 9 (2002). 
These competing theories make it difficult to reach any strong conclusions. The ACLU seems right to emphasize the type of centralization. Consolidation of the intelligence community that maintains certain independence from the White House or from Congress may be most protective of civil liberties, though such independence may also promote abuse. In addition, the division of power among the branches of government likely affects agency conduct. Because united government may produce less meaningful oversight, ${ }^{402}$ redundancy may be more necessary to promote democratic values if the same party controls Congress and the White House. ${ }^{403}$

The effects of structural choices on transparency are likewise uncertain but potentially serious. ${ }^{404}$ Redundant structures could increase the intelligence community's transparency. With more agencies tasked with particular intelligence functions, more information should be available to the public. For example, more Inspectors General will look at how agencies carry out these functions. If agency whistleblowers are any more likely to reveal abuses by agencies other than their own, then an intelligence community with multiple agencies will see more whistle-blowing than an intelligence community consisting of one organization. ${ }^{405}$ Further, if multiple agencies hold particular information, it may be more likely to come out through a leak or official action, such as a response to a Freedom of Information Act request. ${ }^{406}$

Redundant structures could, however, decrease the transparency of intelligence agencies. Additional organizations may increase the amount of information held by the intelligence community and make it more time consuming for reporters, members of Congress, and citizens to understand the activities or status of the intelligence community as a whole. For example, a citizen or policymaker wondering whether any government agency holds particular information may have a harder time accessing information if there are more possible custodians. Also, any single agency in a redundant structure may not have the necessary information about the entire community's activities. Each agency's Inspector General has "the ability to

402. See Levinson \& Pildes, supra note 211.

403. See Katyal, supra note 312 , at 2321.

404. No matter what the structure of the intelligence community, elassification of information may play a large role in the transparency of the intelligence community. Edgar, supra note 398 (calling for establishment of "a bipartisan board, appointed by the President and members of Congress, to review and reform classification rules," revival of the presumption against classification, and broader sharing of "relevant information with the public"). If the Executive Branch adopts a narrow interpretation of the Freedom of Information Act, even if there are more agencies with information, activities of the government will not be transparent. See COLE \& DEMPSEY, supra note 370, at 78; 9/I I Commission REPORT, supra note 3, at 416.

405. Cf. Lowenthal, supra note 243, at 198 (discussing Intelligence Community Whistleblower Act).

406. But cf. 5 U.S.C. $\$ 552$ (b)(1) (2006) (exemption for classified matters that are "to be kept secret in the interest of national defense or foreign policy"). 
obtain any and all records only from... [her own] agencies without a subpoena"; in certain contexts, "it is not entirely clear that a single agency has jurisdiction over a specific substantive power that may affect individual rights and privacy." 407

In sum, as with the civil liberties discussion, it is hard to reach any definitive conclusions concerning which structure of agencies would best promote transparency. Redundant agencies may create more places for information to be hidden, but it seems that, on balance, such an institutional design should often be more transparent than a single agency or unified structure because such duplication should present more opportunities for disclosure.

Likewise, the structure of the intelligence community may enhance or reduce accountability. Decentralized agencies often provide the public, especially organized groups, more opportunities to participate in agency decision making than centralized bureaucracies. ${ }^{408}$ Such participation may improve or undermine accountability. ${ }^{409}$ Redundant structures may increase accountability by making it easier to identify misbehaving agencies. A unified structure may be so powerful that it cannot be held accountable because no institution can challenge it. By contrast, redundant structures may decrease accountability because the public cannot call upon any single agency to account for the failure of the entire community. ${ }^{410} \mathrm{~A}$ unified structure is accountable for all successes and failures and therefore might make officials more vigilant.

The ACLU opposed the 9/11 Commission's recommendation for a NID because of perceived problems with accountability. The 9/II Commission's proposed NID, enacted in the Intelligence Reform Act as the DNI, is to report directly to the White House. According to the ACLU, a unified structure that reports to the President undermines accountability because it serves the political objectives of the President's party. ${ }^{411}$ In the ACLU's view, an independent NID, whom the President could remove only for cause, by contrast, would foster accountability, especially to Congress. ${ }^{412}$

As with the previous two categories, civil liberties and transparency, the relationship between redundancy and unification, on one hand, and accountability, on the other, may be complicated. Answers depend on analyzing the relationship, along with substantive and procedural protections of democratic values. We need empirical evaluation of the interaction of

\footnotetext{
407. Heymann \& Kay yem, supra note 100, at 127.

408. See Thomas, supra note 135, at 464.

409. See supra note 385 and accompanying text.

410. Cf. Freeman \& Farber, supra note 193, at 904-05 (suggesting that accountability could result from answering to other entities within a particular structure).

411. Edgar, supra note 398, at 1 .

412. Id
} 
redundant and unified structures with democratic values to learn which of the effects identified above predominate. Some redundancy within the intelligence community or, alternatively, some independence from the White House could prevent significant abuses that would result from placing too much authority in any one place in the Executive Branch, but that intuition needs support.

\section{Organization of Congressional Oversight}

Congress created the House and Senate Intelligence Committees in reaction to intelligence agencies' violations of core constitutional and democratic values. ${ }^{413}$ As with the intelligence community, the organization of the intelligence community's congressional overseers interacts with these values in complex ways.

Redundant congressional committees could help or hurt civil liberties. More congressional committees with jurisdiction over intelligence matters may be more likely than a single committee to uncover violations of civil liberties or express concern about particular practices. For example, only party leaders and top members of the Intelligence Committees appear to have been informed of the NSA's program to eavesdrop without warrants on international communications with people inside the United States. ${ }^{414}$ After the program was publicly disclosed, the Senate Judiciary Committee conducted hearings on the eavesdropping efforts. ${ }^{415}$ This argument relies, like the parallel argument about effectiveness in promoting national security, ${ }^{416}$ on the capacity of redundancy to increase reliability or operational success. The difference is that, here, operational success is defined in terms of protection of civil liberties.

Furthermore, consolidation of committees could encourage the development of a cozy relationship between congressional overseers and the intelligence community, in which overseers were insufficiently critical of the intelligence agencies' impacts on civil liberties. The ACLU has called for both the House and Senate Judiciary Committees to "retain jurisdiction over intelligence matters affecting legal and constitutional rights," rather than have their responsibilities consolidated under the Intelligence Committees. ${ }^{417}$

Alternatively, more congressional committees with overlapping jurisdiction over the intelligence community may protect civil liberties less than a consolidated committee structure would. Redundancy in oversight may

413. See KAISER, supra note 15 , at 2 .

414. Douglas Jehl, Among Those Told of Program, Few Objected, N.Y. TimEs, Dec. 23, 2005, at A19.

415. See Charles Babington \& Dan Eggen, Gonzales Seeks to Clarify Testimony on Spying, WASH. Post, Mar. 1, 2006, at A8.

416. See supra Section I1.A

417. Edgar, supra note 398. 
lead to free-riding, with no committee adequately protecting civil liberties. If multiple committees oversee intelligence agencies then each committee may havc other responsibilities that compete with intelligence oversight (particularly concerning civil liberties) for committee members' attention. Finally, redundancy may splinter Congress's political authority, leaving no committee with enough power to command protection of civil liberties.

These competing views largely come down to capacity and whether redundancy increases free-riding among committees, assuming that committees that do exercise their authority can protect, to some degree, civil liberties. As with the structure of the intelligence community, redundancy likely is more necessary if the same party controls Congress and the White House.

Like civil liberties, government transparency too may benefit or suffer from redundancy in congressional oversight. ${ }^{418}$ More congressional committees may result in more hearings, requests for information, and other opportunities for members of Congress and the public to learn about intelligence activities. ${ }^{419}$ On the other hand, multiple committees may have a harder time getting a complete picture of the intelligence community's activities, either because they specialize in different aspects of intelligence work or because each committee spends less time studying the entire community than a single, unified committee would. In addition, committees may free-ride, leading to suboptimal levels of oversight and disclosure. A unified committee may be able to coordinate oversight such that more disclosure actually occurs.

As before, these conflicting views do not produce a clear answer. Perhaps, the best structure for promoting transparency values would be a dominant committee in each chamber with sufficient formal and functional authority to obtain necessary disclosures from agencies along with additional, more auxiliary committees to push agencies and the dominant committee to be more forthcoming. Intelligence disclosure laws could be

418. Access to information may be more important than the structure of congressional committees. Cf. supra note 404 and accompanying text. If intelligence hearings are always closed to the public, whether there are more hearings or fewer hearings does not change how transparent the intelligence community is to the public. See Edgar, supra note 398 (calling for committees to "hold far more open hearings"); cf. Eric Lichtblau, Little Progress in Bid to Extend Patriot Act, N.Y. Times, May 27, 2005, at A17 (noting that Senate Intelligencc Committee had met in private to discuss expansions to the Patriot Act); William Safire, Steamroller Out of Steam, N.Y. TimES, Nov. 24, 2004, at A23 (noting that the Senate Intelligence Committee has not released its own report on the U.S.S. Cole terrorist attack). Currently, information on covert operations is reported only to the House and Senatc Intelligence Committees; in exceptional circumstances, such information is disclosed only to the Chairpersons and Ranking Minority Members of those committees and each party's leaders in Congress. See 9/II COMmission RePORT, supra note 3, at 416; Seymour M. Hersh, Get Out the Vote, New Yorker, July 25,2005 , at 52,55 .

419. Transparency has benefits, such as exposing the strengths and weaknesses of agencies, but it also has costs, such as providing details that undermine national security. SMIST, supra note 220, at 275 . 
revised to require the intelligence community to notify the top members on these auxiliary committees-expanding the "Gang of Eight" to a "Gang of Twelve" or "Gang of Sixteen"-about the community's most secretive activities. ${ }^{420}$

Finally, the structure of congressional oversight may influence the accountability of the intelligence community, at least to Congress and perhaps ultimately to the public. As with agency design, redundant committees, if seen as "interlocking constraints," may increase accountability by making it easier to identify misbehaving agencies. ${ }^{421}$ As the ACLU explains,

Limiting the number of committees with jurisdiction over the intelligence community may frustrate oversight instead of enhancing it. If the single committee with jurisdiction over intelligence does not ask probing questions concerning a given program or policy, there will no longer be the potential for another committee to fill the void. ${ }^{422}$

Furthermore, if multiple committees prevented coziness between congressional overseers and agencies, this would enhance accountability. Finally, redundant committees should make it less likely that particular outlying members of Congress will push agency decisions away from the median preferences of all legislators. ${ }^{423}$

On the other hand, redundant committees would decrease accountability if each committee took less or no responsibility for oversight. Critics of congressional oversight of intelligence contend that the current redundant committees "just as often serve as defenders and promoters of the agencies they are supposed to be controlling." 424 A unified structure may make it easier for citizens to assign some blame for intelligence failures to the oversight committees (as well as to the intelligence agencies themselves) and therefore may motivate the members of Congress on those committees to be more vigilant. ${ }^{425}$

As with the previous two categories, the structure of congressional overseers is just one factor in promoting accountability of the intelligence community. Some redundancy in congressional oversight seems desirable, assuming that such overlap promotes vigilance in this important area. At first glance, structural decisions concerning the intelligence community or its congressional overseers may seem quite distant from the protection of core democratic values. These structural choices do not determine the

\footnotetext{
420. Cf. supra note 339 and accompanying text.

421. Cf. COLE \& DEMPSEY, supra note 370 , at 65 .

422. Edgar, supra note 398 , at 9.

423. See supra note 212 and accompanying text.

424. COLE \& DEMPSEY, supra note 370, at 67; see also Ransom, supra note 24, at 165.

425. See Ransom, supra note 24, at 165 ("Accountability in a democratic government applies not only to the executive. It should also apply to Congress.").
} 
scope of civil liberties, government transparency, or agency accountability, but the choices are an important factor to consider to promote these values.

\section{Interaction Between Organization of Intelligence Community and Congressional Oversight}

Like the analysis of the other two perspectives, national security effectiveness and political and legal feasibility, the analysis of constitutional and democratie values must consider how the organization of the intelligence community and the organization of its congressional overseers interact. Because of this interaction, a "democratic values planner" seeking to maximize liberal democratic values should consider both simultaneously when choosing between decentralized (often redundant) and centralized (often nonredundant) intelligence agencies (or some option in between) and between decentralized and centralized oversight (or some option in between). This planner should determine the benefits for civil liberties, transparency, and accountability of various structural combinations, and choose the combination that maximizes these benefits net of their financial and democratic costs. This is a difficult task: these core values may trade off in complex ways. For example, having only one agency monitor email traffic may promote civil liberties but undermine transparency.

The structure of congressional committees probably affects core liberal democratic values more than the structure of the intelligence community does. Historically, oversight has been critical to discovering and correcting violations of these values. It is less clear that the intelligence community's organization has shaped the agencies' respect for these values. Nevertheless, the success of congressional oversight depends on how forthcoming the intelligence community is. A committee structure designed to maximize protection of civil liberties, transparency, and accountability depends on the intelligence community answering, at least to some degree, to Congress. If the intelligence community refuses to answer to Congress, or minimizes the information it discloses, then congressional oversight, no matter how committees are structured, will largely be ineffective. ${ }^{426}$

\section{III}

Combining Perspectives

and the Broader Problem of Agency Design

Each of the three considerations described above-national security effectiveness, political and legal feasibility, and protection of core democratic values-provides a lens through which to view organizational change of the intelligence community and of the community's congressional

426. See Cole \& DempSey, supra note 370, at 47; HeymanN, supra note 256, at 154-56. 
overseers. Commentators and scholars have considered how to combine the first and third issues, examining the balance between national security and democratic values. ${ }^{427}$ An explicit and thorough discussion of political and legal feasibility, however, is also necessary if recommendations for reform are to have any chance of being enacted. ${ }^{428}$

How should policymakers treat these three perspectives, which combine descriptive, causal, and normative elements? This Article proposes that a democratic society should want to maximize national security, net of its financial costs, subject to two constraints. First, any institutional arrangement must be politically and legally feasible. ${ }^{429}$ Second, any organizational change must sufficiently protect critical democratic values (including civil liberties, transparency, and accountability). ${ }^{430}$ The first constraint disposes of utopian or wildly ambitious proposals. The second constraint upholds central governance principles. This formulation may suggest that national security effectiveness is always in tension with core democratic values. But this is not necessarily the case. ${ }^{431}$ Intelligence policy that undermines these core values may also undermine national security. ${ }^{432}$ For example, a policy to monitor all Muslims "encourages stereotyping that not only stigmatizes the innocent but may lull security services into ignoring genuine threats that do not fit an ideological or ethnic pattern." ${ }^{\$ 33}$ In some

427. See, e.g., Amital Etzioni, How Patriotic is the Patriot Act (2004); Heymann, supra note 256; HeymanN \& Kayyem, supra note 100; Posner, supra note 1; Civil Liberties vs. National Security in a Post-9/i i World (M. Katherine B. Darmer, Robert M. Baird, \& Stuart E. Rosenbaum, eds. 2004); Lee \& Schwartz, supra note 181. The 9/11 Commission also recognized there may be a tradeoff. 9/1 I COMMISsion REPORT, supra note 3, at 394-95.

428. Public administration scholars have recognized the need to consider explicitly multiple objectives when analyzing bureaucratic organization, but have not assessed how to balance these objectives. See, e.g., Thomas, supra note 135 , at 484 . Furthermore, 1 know of no work that applies the three objectives 1 have identified in a rigorous manner to the intelligence community and its congressional overseers. Cf. HeYMANN, supra note 256, at 88 (examining briefly "[s]teps useful to reduce the chance and harms of terrorism," "[s]teps dangerous to democratic liberty or national unity," and "[s]teps that reduce public fear and anger").

429. See Thomas, supra note 135, at 467 ("Though largely rejected as an official basis for reorganization, awareness of political constraints makes it possible to achieve limited changes in organizational structure.").

430. One can imagine other ways to combine these perspectives. For example, a democratic society could permit any organizational change with positive net benefits for national security that is politically feasible and that preserves particular democratic values. Or a society could accept an organizational change that is the easiest to adopt politically but that also has positive net benefits for national security and that preserves particular values. Or a society could accept an organizational change that maximizes particular democratic values but that also has positive net benefits for national security and that is politically feasible. And so on. My proposal emphasizes policy effectiveness, within particular constraints, because policy effectiveness is a critical component of institutional design of the administrative state.

431. Edgar, supra note 398 ("Securing the nation's freedom depends not on making a choice between security and liberty, but in designing and implementing policies that allow the American people to be both safe and free.").

432. COLE \& DEMPSEY, supra note 370 , at 178.

433. Id. at 1 . 
instances, however, national security and core democratic values are in tension. ${ }^{434}$ Then it is imperative that policymakers explicitly discuss the tradeoffs and look for alternative mechanisms that achieve the same or a similar level of national security without sacrificing our core values. ${ }^{435}$

In other words, policymakers face what economists would term a constrained optimization problem: policymakers seek to maximize something, here national security effectiveness, but subject to binding restrictions. Establishing the analytical framework is easier than applying it. For the main optimization problem, policymakers must determine the costs and benefits of particular organizational structures for national security. For the first constraint, they must assess political and legal realities. And for the second constraint, they must agree on the scope of particular values and what, in practice, respecting those values means.

The framework proposed here can assist policymakers in identifying, framing, and evaluating the combinations of structures that they may impose on the intelligence community and congressional oversight of it. Figure 1 illustrates these structural choices between decentralization and centralization (alternatively, largely between redundancy and nonredundancy). Further analysis, theoretical and empirical, likely will conclude that some combination of (redundant) decentralization and (nonredundant) unification in both the intelligence community and congressional oversight best promotes national security effectiveness, while being feasible to implement and preserving important democratic values.

This proposed framework applies to structural choices regarding agencies and their congressional overseers in almost any policy area, not just intelligence. To be certain, policymakers will contest what needs to be maximized in a particular arca, and the framework may require some modifications. In the intelligence context, the policy goal is to maximize national security effectiveness. But in other contexts, the aim would be to maximize some other goal (net of its financial costs). Policymakers should adopt structures that maximize that goal subject to political, legal, and democratic legitimacy constraints. Figure 4 summarizes the important factors to consider in this analysis.

434. See Hamdi v. Rumsfeld, 542 U.S. 507 (2004) (Souter, J., concurring in part and dissenting in part and concurring in the judgment) ("The defining character of American constitutional government is its constant tension between security and liberty, serving both by partial helpings of each."); $i d$. (Scalia, J., dissenting) ("The Founders well understood the difficult tradeoff between safety and freedom."); HeYMANN, supra note 256, at 87-88.

435. See HEYMANN \& KAYYEM, supra note 100, at 14 ("It is not possible to have minimal risk from terrorism and absolutely maximally protected freedoms, but we can preserve 90 percent of what concerns each camp. It is possible for legislation to strike a detailed and thoughtful balance between these unattainable absolutes that will endure over the decades ahead."); GEOFFrEY R. STONE, Perilous Times: Free Speech in Wartime from the Sedition Act of 1798 to the War on Terrorism 557 (2004) ("Freedom can endanger security, but it is also the fundamental source of American strength."). 
Figure 4

Maximization Problem:
Effectiveness
(cost-benefit calculation)

Constraint 1:

Political and Legal Feasibility

Constraint 2:

Democratic Legitimacy

\section{Interaction:}

Agency Design and Oversight quality of decision making

group-think

intcrest group capture

competition or cooperation

reliability or free-riding

maintenance costs and returns to scale

policymakers' decision-making costs

monitoring costs

political feasibility

constitutional constraints

statutory constraints

civil liberties

government transparency

accountability

simultaneous choice or consecutive decisions

Consider an example outside of intelligence and national security. How should policymakers structure administrative agencies and congressional oversight to maximize environmental protection, net of its financial costs? Should there be an Environmental Protection Agency with sole jurisdiction over environmental issues? Or should there be multiple agencies with overlapping jurisdictions? If so, should there be a Director of Environmental Protection with authority over all agencies with any environmental authority? Should there be only one committee in each chamber of Congress to oversee any environmental agency? Or should there be multiple committees for oversight? These are just some of the questions that policymakers applying the analytical framework developed in Part II should consider in assessing institutional design for environmental policy.

IV

\section{Proposals}

The 9/11 Commission called for dramatic change in the organization of the intelligence system, from the agencies themselves to their congressional overseers. And some of that change has occurred. The Intelligence Reform Act created a new leader of the intelligence community, the DNI, in the hope that this leader would force agencies to work together to 
prevent future terrorist attacks. The creation of a new box on an organization chart, however, does not guarantee improvement in the operation of a complex community of agencies. DNI Negroponte and his successors face great challenges in the months and years ahead.

Using the framework developed in Parts II and III, I offer four politically feasible and legal proposals for action derived from the above analysis. Two would improve the national security effectiveness of the intelligence community; one would improve the national security effectiveness of congressional overseers; and the last would better protect core democratic values. ${ }^{436}$

First, the DNI should take full advantage of the Intelligence Reform Act's provision for an important redundancy: alternative analysis of intelligence data and conclusions. The Intelligence Reform Act requires that the DNI "establish a process and assign an individual or entity the responsibility for ensuring that, as appropriate, elements of the intelligence community conduct alternative analysis (commonly referred to as 'red-team analysis') of the information and conclusions in intelligence products." ${ }^{437}$ The DNI must report to the House and Senate Intelligence Committees on the implementation of this mandate. ${ }^{438}$ Alternative analysis means more than duplication in analysis. Eight intelligence agencies separately assessed the potential for a terrorist attack during the 2006 Winter Olympic Games in Turin, Italy. ${ }^{439}$ Alternative analysis would require at least one agency to evaluate the work of another agency. This required consideration of alternative analysis easily could become superficial in practice, yielding little or no benefit to intelligence gathering and interpretation. ${ }^{440}$ For example, the DNI could assign an agency to perform this analysis, but if the agency free-rode off of the primary analysis, not much would be gained for enhancing national security.

On the other hand, the statutory mandate could yieId redundancy that did prove meaningful in practice. Increasing the number of people or agencies working on the same raw material, or increasing the different types of raw material or methodologies used to interpret the material, could improve the quality of analysis. If successful, alternative analysis would

436. I offer these proposals with some caution. Parts II and III show that reformers often are overly optimistic about particular structural changes.

437. IRA, $\S 1017$ (a), 118 Stat. at 3670.

438. Id. $\S 1017$ (b), 118 Stat. at 3670 . Various programs appear to be in place: the DIA has a "Devil's Advocate Program"; and the DHS has a "Red Cell" Unit and Alternatc Analysis Division. OfFice of the Director of National intelligence, WMD Commission Recommendations, supra note 72, at 5; see also KAMARCK, supra note 116, at 20.

439. DeYoung, supra note 187 , at AI.

440. See POSNER, supra note 1 , at 124 (alternative analysis is "intellectual equivalent to squaring the circle") (internal quotation marks omitted); Garicano \& Posner, supra note I, at 156 (alternative analysis could lead to "concealment or manipulation of information"). 
combine redundancy and coordination. ${ }^{441}$ The DNI should take this duty seriously, setting up a system that rewards those individuals or agencies tasked with alternative analysis for thinking creatively, even if their efforts do not change outcomes. ${ }^{442}$ For example, the DNI could publicize, at least among those with the requisite security clearances, compelling alternative analysis. Furthermore, policymakers should require good alternativeanalysis work for particular promotions within the intelligence community. Alternative analysis cannot become routine, and thereby undervalued and inadequately performed. ${ }^{443}$

Second, the DNI should work to achieve productive unification in the intelligence community. Unification, by itself, does not ensure better intelligence outcomes. To improve outcomes, restructuring must either increase each agency's ability or desire to do its assigned work (perhaps by requiring agencies to share materials with each other in a productive manner) or decrease the costs of performing that work. Either scenario requires the DNI to wield substantial authority. The Intelligence Reform Act delegates more power to the DNI than that previously held by the Director of Central Intelligence, who headed the CIA and (at least nominally) the intelligence community prior to the new legislation. ${ }^{444}$ The scope of the DNI's power has yet to be determined, however. The statute directs the President to "issue guidelines to ensure the effective implementation and execution within the executive branch of the authorities granted to the Director of National Intelligence by this [act], in a manner that respects and does not abrogate the statutory responsibilities of the heads of the departments of the United States Government concerning such departments . . . ."445 These guidelines, which as of July 2006 have yet to be issued, ${ }^{446}$ need to give the DNI some powerful tools to obtain compliance from the intelligence community. Unlike the Director of Central Intelligence, the DNI does not

441. Lee \& Schwartz, supra note 181, at 1476 ("If separate teams of analysts are to review information, including raw intelligence data, to reach their own analytic judgments, they will also need access to the full range of available information, even if held outside their home agency. Thus, assuming analytic competition is to be institutionalized, it will provide another impetus for widespread sharing of information.").

442. The State Department's "dissent channel" is a potential model. See Katyal, supra note 312, at 2328-31 (describing how foreign service officers can notify the Office of Policy Planning when they disagree with the position of a top official, how top officials must respond to these concerns, and how the Department's personnel system recognizes these reports when determining awards and promotions).

443. See Guiding Principles for Intelligence Reform, Cong. Record, at S9428 (Sept. 21, 2004) (bipartisan statement supporting competition in intelligence analysis); $c f$. PoSNER, supra note 1, at 12324, Brady, supra note 200, at 93; Cass R. Sunstein, Group Judgments: Statistical Means, Deliberation, and Information Markets, 80 N.Y.U. L. REv. 962, 1016, 1020 (2005).

444. See 9/1 I COMMISSION REPORT, supra note 3, at 86 ("[T] he DCl's real authority has been directly proportional to his pcrsonal closeness to the [P/resident, which has waxed and waned over the years, and to others in government, especially the [S]ecretary of [D] efense.").

445. IRA, $\S 1018,118$ Stat. at 3670 .

446. BEST, supra note 21 , at 8. 
command an agency of his own and consequently may lack a ready-made base of support. ${ }^{477}$ The DNI should possess substantial authority to reassign funds and employees from recalcitrant or unproductive agencies to more diligent or successful ones. ${ }^{448}$ The DNI should use this authority judiciously, though. The statute originally permitted the DNI to create a staff of up to 500 people, ${ }^{449}$ but the DNI recently sought authorization for a staff of over 1500 individuals. ${ }^{450}$ At some point, presumably, the added coordination costs from this bureaucratic growth outweigh the benefits those staff can deliver through unifying agency action. ${ }^{451}$

Third, as the 9/11 Commission's members and other groups continue to press for reform of congressional oversight, members of Congress must think carefully about reorganizing committee jurisdictions. The 9/11 Commission concluded that fragmented oversight is hurting intelligence efforts because committees are not investing sufficiently in oversight. ${ }^{452}$ According to the Commission, redundancy in oversight has prevented members of Congress from obtaining needed expertise and from being held accountable for intelligence failures. ${ }^{453}$ It is not clear, however, whether committees are conducting too little or too much oversight. More oversight likely would require intelligence agencies to devote more time to responding to congressional committees' requests, and less time to collecting and analyzing intelligence. Although oversight, even fragmented oversight, potentially provides good incentives for agencies, certain areas, for example, homeland security funding, may face too much oversight, undermining the quality of agencies' work for national security rather than enhancing it. But other areas, for example, implications of intelligence work for government transparency, may confront too little oversight.

If these assumptions receive empirical support, Congress should significantly consolidate, but not entirely unify, its oversight powers involving intelligence agencies, while still ensuring sufficient oversight to protect

447. See 9/ i COMMISSION REPORT, supra note 3, at 414.

448. Critics are skeptical that the DNI will have sufficient authority. Some have even suggested that the recent legislation does more harm than the relatively decentralized system it replaced. See Seymour M. Hersh, The Coming Wars, NEw Yorker, Jan. 24 \& 31, 2005, at 40, 47 ("'The intelligence system was designed to put competing agencies in competition. What's missing will be the dynamic tension that insures everyone's priorities-in the C.I.A., the D.O.D., the F.B.I., and even the Department of Homeland Security-are discussed. The most insidious implication of the new system is that Rumsfeld no longer has to tell people what he's doing so they can ask, Why are you doing this? or What are your priorities? Now he can keep all of the mattress mice out of it.") (quoting unnamed former high-level intelligence official) (some internal quotation marks omitted).

449. IRA, § 1096(b)(1), 118 Stat. at 3698.

450. See supra note 69 and accompanying text.

451. Cf. Posner, supra note 54, at A23 ("For there is that 500-member staff [the DNl's] been authorized. He can lay it like a blanket of fog over the intelligence community and allow the agencies beneath it to breathe only if they make reciprocal concessions.").

452. See 9/1 I COMMISSION REPORT, supra note 3, at 419.

453. Id. at 420 . 
core democratic values. The potential costs of consolidation for reliability could be offset by giving more power to the ranking minority members on the remaining committees with jurisdiction over the intelligence community. For example, the ranking minority members of the Intelligence Committees could be given subpoena power and the authority to call hearings. ${ }^{454}$ Members who are in the majority may support such a proposal if they fear being in the minority in the future.

Nevertheless, the 9/I I Commission's call to staff intelligence committees with members of Congress who would serve "indefinitely" seems neither politically feasible nor desirable for national security. ${ }^{455}$ Although longer tenures on such oversight committees could generate helpful expertise, they also could promote cozy relationships between the overseers and the targets of oversight, as well as reduce creative thinking on intelligence issues. Instead, a smaller number of committees should have jurisdiction over the intelligence community (or some part of that community), and members of those committees should have staggered terms, so that some members always have considerable expertise while others bring potentially critical new ideas. For example, a quarter of each intelligence-related committee could turn over every two or four years (separate, of course, from electoral turnover). In addition, these committees should be as evenly balanced as possible. Rotating terms and party parity might also encourage consolidation of committees, if members felt they had a realistic chance of serving on one of the consolidated committees. A member on a committee that oversees some small part of the intelligence community might be willing to give up that jurisdictional authority for the opportunity to serve a fixed term on a committee that oversees more of the intelligence community. Further, a member of the minority party might be willing to relinquish such authority even if she did not anticipate being in the majority party in the near future because party parity on the consolidated committees would provide more committee seats to the minority party.

Fourth, policymakers should more vigorously protect core democratic values as they oversee the implementation of the Intelligence Reform Act and contemplate changes to their own committee structure. The Executive Branch should make the intelligence community's budget public, including its major divisions. ${ }^{456}$ It also should conduct internal reviews within the

454. Congress gave this authority to the minority party when it established the House Select Bipartisan Committee to Investigate the Preparation for and Response to Hurricane Katrina, but the Minority Leader refused to appoint members to the Committee, fearing that the Committee would sugarcoat its assessment. See House Select Bipartisan Committee to Investigate the Preparation for and Response to Hurricane Katrina, A Failure of lnitiative, at 10 (Feb. 15 , 2006).

455. 9/I I COMMISSION RePORT, supra note 3, at 421.

456. Id. at 416; $9 /$ I I Public Discourse Project, supra note 89, at 9 . The DNI recently disclosed that the U.S. had almost 100,000 intelligence personnel. 100,000 Staff Intelligence Community, USA TodAy, Apr. 21, 2006, at 9A. The Senate Intelligence Committee has voted to make the National 
community that assess not only national security effectiveness but also protection of important democratic values, which should then be provided to key congressional committees. Unclassified summaries should be released to the public. Finally the Executive Branch should take the Privacy and Civil Liberties Oversight Board seriously. In its final report card at the end of 2005, the 9/11 Public Discourse Project gave the Board a " $D$ " grade: "The Board has yet to be constituted. To date no meetings have been held; no staff have been named; no work plan has been outlined; no work has begun; no office has been established."457 Although the President appointed the Board's members in June 2005, the Chairwoman and Vice Chairman were not confirmed until February $2006 .{ }^{458}$ The first meeting occurred in March 2006. ${ }^{459}$ The Executive Branch should give the Board members and their staff sufficient security clearances and broad authority to require agencies to turn over information on their activities. The Board should make regular, formal assessments of agencies' respect for core democratic values and those assessments should be made public, even if classified portions are redacted.

The Legislative Branch, too, should act more vigorously to protect democratic values. Congressional committees with jurisdiction over the intelligence community should mandate that intelligence agencies report regularly to them on their actions and how those actions affect democratic values, and provide unclassified versions of such reports for public release. Congress should also create subcommittees on civil liberties within intelligence-related committees, if they do not already exist. And Congress should amend the intelligence oversight statutes to require that more members of Congress, at least some of whom are not on the Intelligence Committees, be notified of intelligence activities. ${ }^{460}$

\section{$\mathrm{V}$ \\ CONCLUSION}

Agency design is a complex but critical enterprise. Structural choices in the administrative state can significantly affect agencies' performance. This Article has offered a framework for considering the design of public organizations and congressional oversight committees. This framework

Intelligence Program's costs public. S.3237, $\S 307$ 109th Cong. (2006); Walter Pincus, Panel Requires Annual Disclosure of Intelligence Budget, WASH. Post, May 28, 2006, at A6.

457. 9/1 I Public Discourse Project, supra note 89, at 9; see also id. at 3 (giving the Board a "D" grade).

458. Id. at 7 .

459. White House, Privacy and Civil Liberties Oversight Board, http://www.whitehouse.gov/ privacyboard. Its fourth meeting occurred in May 2006. House Permanent Select Committee on INTELLIGENCE SUBCOMMITTEE ON OVERSIGHT, supra note 77, at 24.

460. The Senate Intelligence Committee wants all of its members to be informed of particularly sensitive intelligence activities. Report of Senate Select Committee on Intelligence to Accompany 3237 , at $\S 304$; Pincus, supra note 456. 
maximizes organizational effectiveness, subject to political, legal, and democratic legitimacy constraints. Applying this combination of perspectives recasts the 9/11 Commission's major proposals on the structure of the intclligence community and its congressional monitors. Carrying out the prescribed analysis in detail will not be easy, whether the subject is intelligence and national security, or any other area of the administrative state. The 9/11 Commission remarked in its report that "[i]magination is not a gift usually associated with bureaucracies." 461 But both serious analysis and imagination are required to design effective, feasible, and democratically desirable bureaucratic structures.

\section{GAME THEORY APPENDIX}

This Appendix considers more formally the advantages and disadvantages of redundancy and unification in the intelligence community and its congressional overseers for effectiveness in enhancing national security. The Appendix starts with a slightly modified version of Ting's two-player game theory example of strategic redundancy. ${ }^{462}$

\section{I}

\section{ORGANIZATION OF THE INTELligenCE COMMUNITY}

Imagine that Congress selects two agencies, one military and one civilian, to obtain certain intelligence. Although the intelligence community has sixteen members, ${ }^{463}$ reducing this set to two entities, the Defense Department and the CIA, is a less dramatic simplification than it may seem at first. Agencies under the purview of the Defense Department - the NSA, NGIA, NRO, DIA, and service intelligence agencies-consume approximately $80 \%$ of all government intelligence spending. ${ }^{464}$ And the CIA, the only entity not part of a cabinet department, is the most important, or at least the best known, agency in the intelligence community. ${ }^{465}$

Assume, in addition, that each agency independently may succeed or fail in getting desired information. Specifically, imagine that each agency succeeds with probability $s$, where $s$ falls between 0 and $1(0 \%$ and $100 \%)$

\footnotetext{
461. $9 / 11$ COMMISSION REPORT, supra note 3 , at 344 .

462. Ting, supra note 121 , at 277 . 1 do not assume, as Ting does, that the cost of working is always less than the reward to working. This change in assumption allows both agents to shirk in a Nash equilibrium. 1 also change the payoff to both agents shirking so as to capture more intuitively the possibility of a disaster from no agent working. As with any model, this model makes simplifying assumptions, some more realistic than others. For example, the model assumes that agencies either work to collect needed information or do not; there is no continuum of effort. In addition, the model assumes that agents cannot bargain to the most efficient outcome. But despite these simplifying assumptions, the model illustrates some key insights about redundancy and unification in bureaucratic organization.

463. See supra notes $19-22$ and accompanying text.

464. $9 /$ I I COMMISSION REPORT, supra note 3, at 86.

465. See id.
} 
and where $s$ is independent across the agencies. ${ }^{466}$ The independence of the probability $s$ across the agencies would hold if, for example, the agencies used different techniques in their efforts and did not share information with each other. ${ }^{467}$ (To be certain, agencies likely have different probabilities of success at a given task and share some information with each other.) If either agency prevails in obtaining the intelligence, we term the outcome "positive"; if neither agency prevails, we see the outcome as "negative." Further, if neither agency prevails, there is a chance that some disaster (for example, a terrorist attack) will occur, which we term a "disastrous" outcome. Later in this Appendix, I relax this assumption that one agency's work does not affect any other agency's probability of success $s$-two agencies working on the same problem may produce positive externalities (for example, innovation) or negative externalities (for example, interference).

If the agencies do not behave strategically (i.e., if an agency's chance of prevailing is not affected by the existence of another agency with an overlapping mandate), the chance that the information will be obtained is $s$ for one agency and $s+(\mathrm{I}-s) s$ for two agencies. ${ }^{468}$ As long as there is some chance of success (i.e., $s$ is greater than 0 ), the probability of a good result is greater with two agencies working on the task than with one.

As explained above, ${ }^{469}$ administrative agencies, however, tend to behave strategically. They consider the efforts of other agencies tasked with similar work when deciding how hard to work themselves. Assume that the two agencies receive the following payoffs from the outcome: 1 if there is a positive outcome, 0 if there is a negative outcome, and -1 if there is a disastrous outcome. Each strategic agency decides either to work or shirk. If an agency chooses to work, its chance of succeeding is $s$; if the agency chooses to shirk instead, its chance of succeeding is 0 . (To be certain, agencies generally choose to work along some continuum; this model uses the binary choice for simplicity and basic organizational insights. Further, this modeI treats agencies as unitary actors, ignoring that they too face their own principal-agent problems within the organization.)

Work is not without costs: if the agency works, it must pay a cost $c$, which ranges between 0 and 1. If that cost is sufficiently high, an agency will choose not to work. Such a decision does not necessarily reflect bad faith on the part of the agency (for example, telling all of its employees to knock off work and read Television Without Pity on the Internet). As the

466. The model defines success as the agency obtaining the desired information. To be certain, policymakers must then utilize that information to avert disaster. This model thus assumes that policymakers make use of intelligence.

467. Ting, supra note 121 , at 277.

468. Probability of one agency getting the information + probability of second agency getting the information - probability of both agencies getting the information: $s+s-s^{2}=s+(1-s) s$.

469. See supra notes $130-133$ and accompanying text. 
9/11 Commission explains, government agencies “are often passive, accepting what are viewed as givens, including that efforts to identify and fix glaring vulnerabilities to dangerous threats would be too costly, too controversial, or too disruptive." 470 Alternatively, an agency simply may not know what it needs to do. It "shirks" because it does not have needed direction. But shirking too has costs. If no agency works, a disaster strikes, with probability $d$. A disaster cannot strike if at least one agency works.

Each agency wants a positive outcome and, if acting alone, it will work so long as the net benefit of working outweighs the net benefit of shirking. The net benefit of working is determined by multiplying the benefit of a good outcome by its likelihood (to find the expected benefit) and subtracting the cost of working. The cost of shirking is determined by adding the expected cost of a negative outcome to the expected cost of a disastrous outcome. In technical terms, each agency will work if $s(1)-c \geq(1-s)(0)+d(-1)$, or $s \geq c-d$. Each agency realizes, however, that its work is wasted if the other agency prevails in its efforts. Figure A.I, a payoff matrix, illustrates this game between two strategic agencies:

Figure A.1

Agency 2

\begin{tabular}{ll|c|c|}
\multicolumn{1}{c}{} & \multicolumn{1}{c}{ Work } & \multicolumn{1}{c}{ Shirk } \\
\cline { 3 - 4 } Agency 1 & Work & $2 s-s^{2}-c, 2 s-s^{2}-c$ & $s-c, s$ \\
\cline { 3 - 4 } & Shirk & $s, s-c$ & $-d,-d$ \\
\cline { 3 - 4 } & & &
\end{tabular}

In each cell, Agency 1's payoff is listed first; Agency 2's payoff is listed second. The model assumes that the two agencies cannot bargain with each other to obtain different payoffs.

In a noncooperative game with strategic players, we look for optimal strategies for the players; the combination of such strategies constitutes a Nash equilibrium. More precisely, a Nash equilibrium of this game "is an array of strategies, one for each player, such that no player has an incentive (in terms of improving his own payoff) to deviate from his part of the strategy array." 471 In other words, in a Nash equilibrium, "each player is maximizing on his own, given the supposed actions of the others." 472 Here, the array (work, work), where the strategy for Agency I is listed first and the strategy for Agency 2 is listed second, is a Nash equilibrium if and only if $2 s-s^{2}-c \geq s$. Simplifying, both agencies working is a Nash equilibrium if and only if $s$ falls between $1 / 2(1-\sqrt{1-4 c})$ and $1 / 2(1+\sqrt{1-4 c}) .^{473}$

470. See 9/1 I COMMISSION REPORT, supra note 3, at 352.

471. David M. Kreps, Game Theory and Economic Modeling 28 (1990).

472. Id.

473. The quadratic formula provides this solution to $2 s-s^{2}-c \geq s$. 
Figure A.2 illustrates the conditions for this equilibrium. The horizontal axis shows various values for the cost of working, $c$; the vertical axis shows various values for the probability of success, $s$. Pairs that fall in between the two curves constitute values of $c$ and $s$ where both agencies working is a Nash equilibrium. For example, if there is no cost of working (i.e., $c=0$ ), all values of $s$ would result in such an equilibrium; such a situation corresponds to the nonstrategic environment. As the cost of working increases, there is a smaller range of values for $s$ where both agencies working constitutes a Nash equilibrium. As Ting explains, " $[s]$ must be moderate and $c$ low for both agen[cies] to work. When $[s]$ is low, the marginal contribution of the second agen[cy] is too low to justify the cost, while a high $[s]$ leaves little room for improvement." 474

Figure A.2

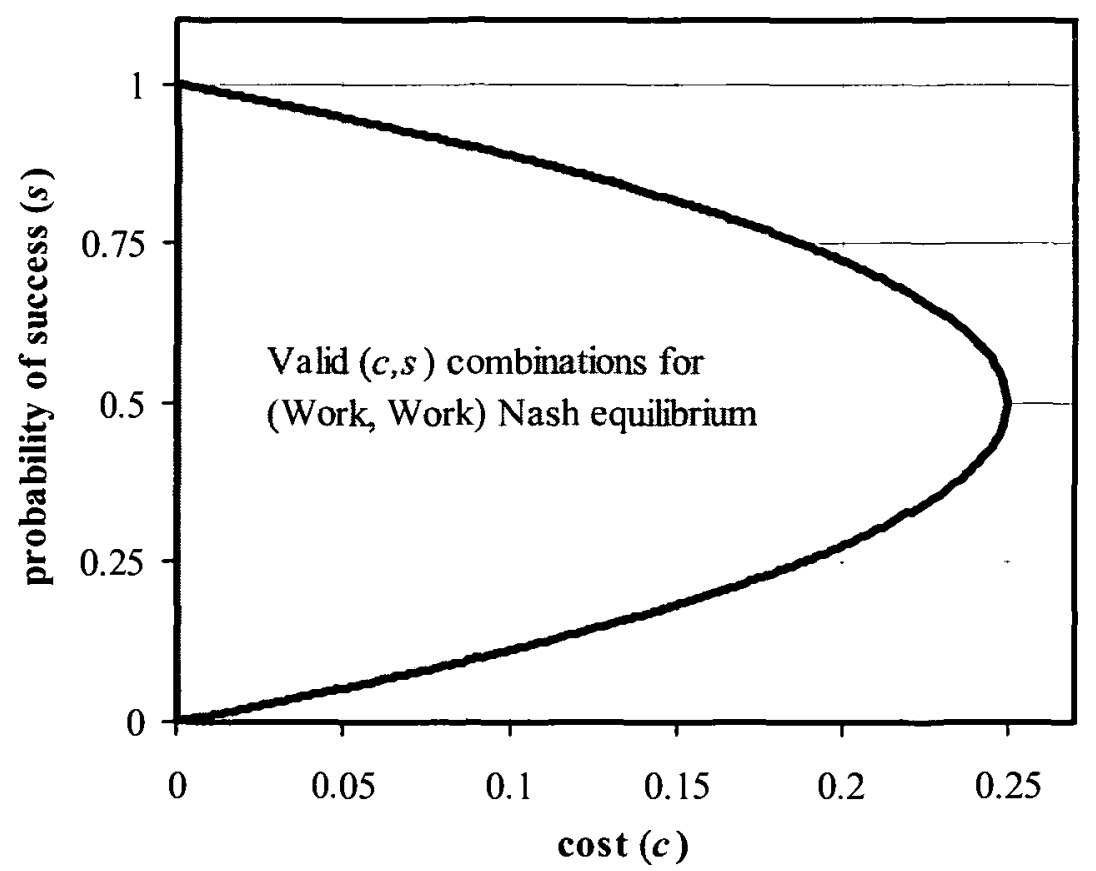

In other words, redundant, strategic agencies will both work on the same task if each thinks its contribution to the task's success is worth its costs. Those proposing or effectuating changes in bureaucratic structure should not overlook this critical insight. Agencies are strategic players; any benefits of redundant structures depend on the redundant structures deciding to work.

474. Ting, supra note 121 , at 277. 
Unlike Ting's set-up, the game described here allows the possibility that both agencies shirk in a Nash equilibrium. More precisely, the array (shirk, shirk), where, as before, the strategy for Agency 1 is listed first and the strategy for Agency 2 is listed second, is a Nash equilibrium if and only $-d \geq s-c$. In other words, the payoff to shirking must be at least as great as the payoff to working. Because the payoff to shirking is nonpositive by assumption $(-d \leq 0)$, there is a shirking equilibrium only if $s \leq c-d$, or when the cost of working discounted for the possibility of a disaster if both agencies shirk is greater than the probability of one agency prevailing. In the intelligence context, this seems like a rare occurrence. Presumably the chance of a disastrous outcome should motivate agencies to work. Agencies, however, could underestimate the probability of a disastrous outcome, as they may have done prior to September 11, 2001. If neither the condition for the (work, work) array nor the condition for the (shirk, shirk) array holds, the array (work, shirk) or (shirk, work) should be a Nash equilibrium.

What does this simple game theory model tell us about the decision to delegate intelligence work to one agency or to multiple agencies? If both agencies choose to work in equilibrium and Congress receives the same payoffs as an agency (i.e., there is no additional cost of delegating), Congress should delegate to both agencies because the payoff to both agencies working is greater than the payoff to one agency working: $2 s-s^{2}-c \geq s-c$ or, simplifying, $s-s^{2} \geq 0$. Agencies, however, typically require resources. If both agencies work in equilibrium, and Congress pays $l$ to maintain each agency, whether or not the agency works on its assigned tasks, ${ }^{475}$ Congress should delegate to both agencies if the net payoff (including this cost of maintaining an agency) is greater with two agencies, than with one: $2 s-s^{2}-c-2 l \geq s-c-l$ or, simplifying, $s-s^{2}-l \geq 0 .{ }^{476}$ If both agencies choose to shirk in equilibrium, or if one agency works but the other shirks in equilibrium, Congress should not delegate a particular task to both agencies if there is any cost of delegating to a second agency.

The 9/11 Commission did not, however, ask Congress to dclegate intelligence work to fewer agencies, but rather proposed that the agencies tasked with intelligence functions report, in essence, to one boss, the National lntelligence Director, and that agencies use joint intelligence

475. In real-world terms, Congress may have to provide funding to each agency; that funding could be used for other government programs if it were not used hcrc. See supra note 134-136 and accompanying text.

476. A similar result obtains if the cost of maintaining Agency I differs from the cost of maintaining Agency 2. Assume $m$ is the cost of maintaining Agency 1 and $n$ is the cost of maintaining Agency 2. Congress should delegate to both agencies instead of Agency 1 alone if $2 s-s^{2}-c-m-n \geq s-c-m$ or, simplifying, $s-s^{2}-n \geq 0$. (To compare delegation to both with delegation to Agency 2 alone, replace $n$ with $m$ in the last equation above.) 
resources instead of relying entirely or predominantly on their own resources.

When is such "consolidation" of agencies beneficial? Assume the "unification" of the CIA and Department of Defense yields a payoff to Congress of $s^{\prime}-l^{\prime}$ when the unified agencies work (i.e., the payoff is the chance of a positive outcome discounted by the cost of delegating to and maintaining the agency). As described above, if the CIA and the Defense Department are separate entities, each tasked with intelligence work and each relying on its own resources, Congress's payoff to both agencies working is $2 s-s^{2}-2 l$. If both agencies would work in equilibrium (i.e., there is no collective action problem), then the unified payoff, $s^{\prime}-l^{\prime}$, must be compared with the nonunified payoff, $2 s-s^{2}-2 l$. Thus, as the difference in cost between, on the one hand, delegating to two separate agencies that do not report to the same "boss" and that rely on independent resources and, on the other hand, delegating to a unified intelligence community that can share resources (that is, $2 l-l$ ) grows, all else being equal, the payoff to a unified intelligence community also grows.

Similarly, as the difference in benefits between delegating to two separate agencies and delegating to a unified intelligence community $\left(2 s-s^{2}-s\right)$ grows, all else being equal, the payoff to a redundant intelligence community also grows. The chance of a positive outcome from the unified bureaucratic structure, $s^{\prime}$, may well be lower than the chance of a positive outcome from a decentralized bureaucratic structure, where both agencies work, $2 s-s^{2}$.

In addition, redundant structures may create positive externalities. Such a positive externality is not represented in the payoff structure but could be easily added: $2 s-s^{2}+p e$, where pe represents the positive interaction cffect. Structures also may create negative externalities. Such a negative externality is not represented in the payoff structure but could be easily added: $2 s-s^{2}-n e$, where ne represents the negative interference.

Figure A.3 presents several different scenarios of the possible costs and benefits of a nonunified and unified intelligence system (with no externalities associated with redundant agencies). The first and fourth lines provide examples in which two nonunified agencies yield a better chance of finding the desired information than the agencies as a unified structure would. The second and third lines provide examples in which the unified agencies yield a better result. 
Figure A.3

$\begin{array}{ccccccc}\boldsymbol{s} & \boldsymbol{l} & \begin{array}{c}\text { nonuuified } \\ \text { payoff }\end{array} & \boldsymbol{s}^{\prime} & \boldsymbol{l} & \begin{array}{c}\text { unified } \\ \text { payoff }\end{array} & \begin{array}{c}\text { preferred } \\ \text { bureaucratic } \\ \text { structure }\end{array} \\ 0.2 & 0.05 & 0.26 & 0.3 & 0.05 & 0.25 & \text { nonunified } \\ 0.4 & 0.05 & 0.54 & 0.7 & 0.05 & 0.65 & \text { unified } \\ 0.2 & 0.10 & 0.16 & 0.4 & 0.20 & 0.20 & \text { unified } \\ 0.4 & 0.10 & 0.44 & 0.6 & 0.20 & 0.40 & \text { nonunified }\end{array}$

This model assumes that agencies are strategic and that there are costs of delegating. How these assumptions interact determines whether Congress, if motivated solely by maximizing effectiveness for enhancing national security, will want to delegate either to redundant agencies, to unified agencies, or to only one agency.

\section{II}

\section{Organization OF CONGRESSIONAL Oversight}

For the "national security planner," what structure of congressional oversight is optimal: one that emphasizes redundancy or one that emphasizes unification? Using the framework developed in the previous Part, this Part considers common assumptions about the effects of oversight, on agencies and on Congress.

Consider first the effect of oversight on agency action, where oversight imposes a cost on each agency, $a$, that does not depend on the agency's decision to work or shirk. Figure A.4 illustrates the modified payoff matrix:

Figure A.4

\begin{tabular}{ll|c|c|} 
& \multicolumn{2}{c}{ Agency 2 } \\
\cline { 3 - 4 } Agency 1 & Work & Shirk \\
\cline { 3 - 4 } & Shirk & $2 s-s^{2}-c-a, 2 s-s^{2}-c-a$ & $s-c-a, s-a$ \\
\cline { 3 - 4 } & $s-a, s-c-a$ & $-d-a,-d-a$ \\
\cline { 3 - 4 } & &
\end{tabular}

As before, in each cell, Agency l's payoff is listed first; Agency 2's payoff is listed second. Under this assumption, oversight does not change an agency's decision to work or shirk in equilibrium because it imposes the same cost no matter the agency action (or inaction). The only effect of oversight is to lower the agencies' payoffs.

The cost of oversight felt by an agency, however, likely depends on the oversecr's perception of the agency's performance, with agencies that shirk facing more of a penalty from oversight than agencies that work. Let 
$a_{w}$ be the cost of oversight to an agency that works, and $a_{s}$ be the cost of oversight to an agency that shirks. If an agency that shirks faces greater wrath from congressional overseers (such as hudget cuts, reporting requirements or hostile questioning) than an agency that works, $a_{s}$ will be greater than $a_{w}$. Figure A.5 illustrates this slight change in assumption.

Figure A.5

\begin{tabular}{rl|c|c|}
\multicolumn{3}{c}{ Agency 2 } \\
Agency 1 & Work & Shirk \\
\cline { 3 - 4 } & Shirk & $2 s-s^{2}-c-a_{w}, 2 s-s^{2}-c-a_{w}$ & $s-c-a_{w}, s-a_{s}$ \\
\cline { 3 - 4 } & $s-a_{s}, s-c-a_{w}$ & $-d-a_{s},-d-a_{s}$ \\
\cline { 3 - 4 } & &
\end{tabular}

Both agencies will work in equilibrium if $s$ falls between $1 / 2\left(1-\sqrt{I-4\left(c+a_{w}-a_{s}\right)}\right)$ and $1 / 2\left(1+\sqrt{I-4\left(c+a_{w}-a_{s}\right)}\right)$. Because $a_{s}>a_{w}$, the earlier analysis, depicted in Figure A.2, still holds, except for a wider range of costs. Furthermore, both agencies will shirk in equilibrium only if $-d-a_{s} \geq s-c-a_{w}$, which simplifies to $s \leq c-d-a_{s}+a_{w}$. Given that $a_{s}>a_{w}$, the earlier analysis for a (shirk, shirk) equilibrium still holds, except for a smaller range of costs. In other words, differentiated oversight costs decreases the cost of working. For some agencies, oversight will change their decision to shirk into a decision to work. For those agencies that would have chosen to work without any oversight, congressional monitoring instead has reduced their payoffs to working. Thus, to the extent that oversight encourages agencies to work, oversight improves ultimate outcomes. ${ }^{477}$

In addition to imposing costs on agencies, congressional oversight may also improve agency payoffs. For example, such oversight could improve an agency's chance of succeeding at its task by making the agency's efforts more efficient. With one agency, if congressional oversight is, on balance, beneficial, the payoff to the agency should increase. If the payoff to working increases, the agency should be more likely to work than to shirk; once the payoff to working is greater than the payoff to shirking, the agency will work, all else being equal. With two agencies, however, such beneficial oversight will make it less likely that both agencies will work. Consider Figure A.2. As $s$ increases, for a given cost $c$ of working, the chance that the pair of values leads to both agencies working in equilibrium (i.e., that the pair will fall within the shaded region in Figure A.2) declines. In other words, assuming agencies are strategic, where there is

477. This analysis presumes the decision to delegate is separate from the decision to exercisc oversight so that both decisions are not set endogenously in the model. Section 11.A.3, supra, discusses the connections between the structure of the intelligence community and the structure of congressional oversight. 
redundancy in delegation, "beneficial oversight" (that is, oversight that increases the chance of a working agency succeeding at its task) will make it less likely that all of the redundant agencies will work. This occurs because there is less chancc of redundant action making a difference.

The observed level of oversight, of course, critically depends on its payoff to Congress, which may overlap somewhat with its payoff to the agencies. In tcrms of benefits, redundant oversight may bring more opportunities to members of Congress to claim credit in front of constituents and to improve agency work. In terms of costs, oversight may expose members of Congress to punishment by their constituents or may make agency work more difficult. 